\title{
VARIAÇÃO GENÉTICA EM PROGÊNIES DE Lucalyptus saligna SMITH E SUA INTERAÇÃO COM O ESPAÇAMENTO
}

\author{
FERNANDO PATIÑO - VALERA \\ Engo Agrónomo - Esp. en Bosques \\ Instituto Nacional de Investigaciones Forestales e \\ Agropecuarias - INIFAP - MÉXICO
}

Orientador: Prof. Dr. PAULO YOSHIO KAgEYAMA

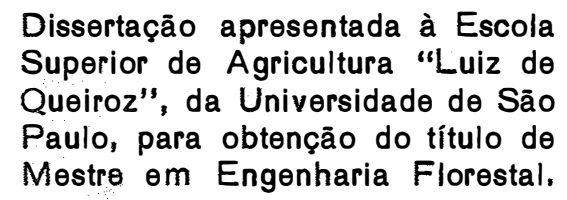

PIRACICABA

Estado de São Paulo - Brasil

Abril de 1986 
A Mayita e aos mous irmãos: José Luis, Juan Antonio, Amália, Salvador, Enrique, Manuel, María Elvira, Arturo, María de Lourdes e Ricardo,

MINHA CONSTUERAÇAO .

A memōria do meu pai: Eng Agrônomo FERNANDO PATINO-NAVARRETE, quem me iniciou e incentivou scmpre para seguir no caminho da pesquisa, e

A minha esposa Juanita e aos meus filhos Juan Fernando e Mônica Elisa, OFERECO E DEDICO. 


\section{AGRADECIMENTOS}

Os meus sinceros agradecimentos as pessoas e institui ções que contribuíram direta ou indiretamente na realizaçäo deste trabalho, e em especial deferência:

Ao orientador e amıgo, Prof. e Dr. Paulo. Yoshio Kagey ama, pela sua dedicação e interesse e pelo incentivo e con fiança que sempre conseguiu transmitir durante o curso de pós-Graduação, além de sua compreensão às barreiras de língua e aos problemas enfrentados na realização deste trabalho.

Ao Instituto Nacionäl de Investigaciones Forestales e Agropecuarias (INIFAP) do México, com especial deferēncia aos amigos, Drs. Jesús Morcada De la Fuenie, vocal ejecutivo, e Miguel Caballero Deloya, vocal secretārio de Investigación Forestal, pela oportunidade de reálização do curso de Pós-Gra duação e pelas facilidades outorgadis paxa minha estadia no Brasil.

Ao Instituto de Pesquisas e Estudos Florestais, pelas facilidades e ajuda prestadas, em especial ao Tëcnico em Com putação Jair Augusto Diehl, pela su valiosa ajuda no desen volvimento dos programas de computação para as diversas aná lises da variância e a sua ampla cooperação no processamento dos dados deste trabaiho. 
A Companhia Reflorestadora Nacional (CIRENA) do Grupo RIPASA, com especial deferência aos Engenheiros Florestais Edson Antonio Balloni e Josê Zani Filho, e ao Técnico José Cesar Bistaffa, do Departamento de Pesquisa e Desenvolvimen to Florestal, pelas facilidades outorgadas e a valiosa ajuda no estabelecimento e condução dos ensaios e na coleta dos da dos experimentais.

Registro também a minha gratidão aos docentes dos De partamentos de Silvicultura e Genética da ESALQ-USP, pelos ensinamentos, ajuda e pela amizade oferecida.

Aos amigos do curso, que participaram sempre das cons tantes trocas de idéias, fazendo valiosas sugestões para o melhor desenvolvimento deste trabalho, en especial ao Märio Luiz Teixeira de Moraes, Edson Seizo Mori, Paulo Kikuti e Valderes Aparecida de Sousa.

As laboratoristas do Setor de Sementes do Departamen to de Silvizultura da ESALQ, com especial deferência para $A I$ ba Valëria Masetto, pela ajuda na realização das determinações da densidade básica da madeira, e no manejo dos dados experimentais dos testes.

Às funcionärias da Biblioteca do Instituto de Pesquisas e Estudos Florestais (IPEF), Marialice Metzeker Poggiani e Magali Oliveira Salgueiro, pelo apoio concedido. 
A todos os funcionários do Departamento de Silvicultu ra da ESALQ-USP e do IPEF, pelo apoio e amizade oferecidos no decorrer do curso.

Aos amigos Juan e Esperanza Medina, Yone Simöes, Maria Arcadolina Sabilión e Norman Alexis e Gioconda Sabillón, pe 10 apoio e amizade oferecidos, sobretudo nos momentos difíceis desta fase de minha vida.

A Publique Central de Serviços Ltda., pela datilogra fia e a edição do presente trabalho.

Uma deferência muito especial para Juanita, Juan Fer nando e Mönica Elisa, que me apoiaram, incentivaram e participaram desta fase da minha formação.

Ao Povo Brasileiro pela amizade e calor humano, e pe 1 a oportunidade de aprender nas suas instituiçoes, a minha gratidão . 
1. INTRODUÇAO $\ldots \ldots \ldots \ldots \ldots \ldots \ldots \ldots \ldots \ldots \ldots \ldots \ldots \ldots \ldots \ldots \ldots$

2. REVISÃo DE Literatura................... 6

2.1. Efeitos do espaçamento entre plantas........ 6

2.2. Interação genótipo $x$ ambiente........... 19

2.3. Ensaios de progênies e determinação de parâme tros genéticos................. 36

2.3.1. Ensaios de progênies........... 36

2.3.2. Determinação de parâmetros genéticos.. 41

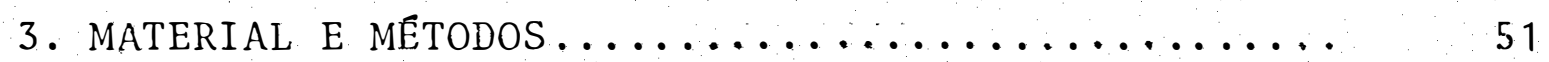

3.1. Material.................... 51

3.1.1. Descrição da população.......... 51

3.1.2. Localização e características da área da popu lação .................. 53

3.1.3. Características do local de estudo........ 53

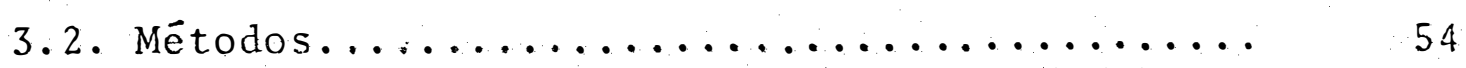

3:2.1. Instalação e condução do teste de pro-

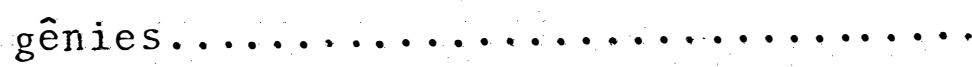

3.2.2. Delineamento experimental........ 55

3.2.3. Avaliação dos ensaios........... 57

3.2.4. Análise da variância individual para cada uma das características em cada

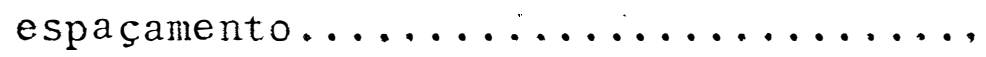


3.2.5. Análises da variância conjuntas para espacamentos e idades.............

3.2.6. Análise da covariância entre idades para cada característica e entre caracteristicas para cada idade.......

3.2.7. Estimativas dos parâmetros genéticos

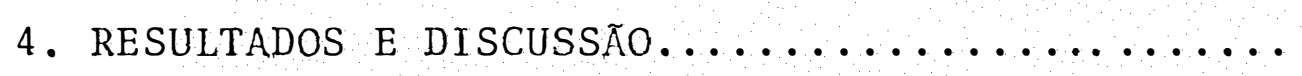

4.1. o crescimento das progênies............ 74

4.1.1. Sobrevivência das progênies....... 74

4.1.2. Crescimento em altura........... 78

4.1.3. Crescimento em diâmetro das progê-

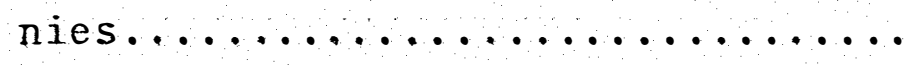

4.1.4. Crescimento das progênies em ärea basal e volume cilindrico......... 4.1.4.1. Area basal........... 91

4.1 .4 .2 . Volume cilindrico........ 95

4.1.5. Densidade básica da madeira....... 98

4.2. Resultados das anālises da variância indi-

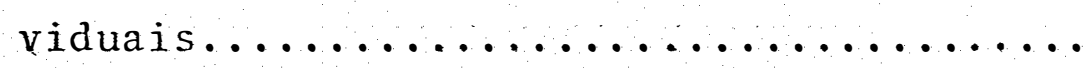

4.3. Resultados das análises da variância conjuntas para as características de crescimento e forma do tronco envolvendo os espa çamentos testados e as idades avaliadas... 
.vii.

pāgina

4.4. Correlação entre os espaçamentos para as di

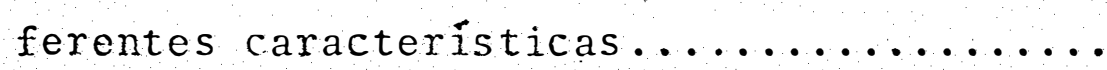

4.5. Estimaşão das variâncias genéticas e não ge néticas e de coeficientes de herdabilidade e de variação genéticas e não genéticas para altura, diâmetro, área basal, volume cilindrico e forma do tronco...............

4.6. Relações entre coeficientes de variasão genética e experimental, e entxa as variâncias dentro e entre nrogênies, e entre as variâncias dentro e ambienta $\ldots . . . \ldots \ldots \ldots$

4.7. Coeficientes de correlaşão genética e fenotípica entre as características de altura, diâmetro e volume cilindrico para os dois espaçamentos testados, nas idades de 26 e

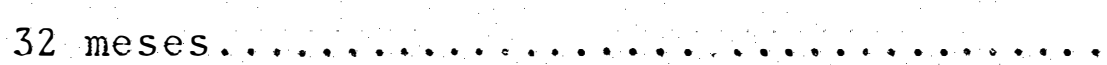

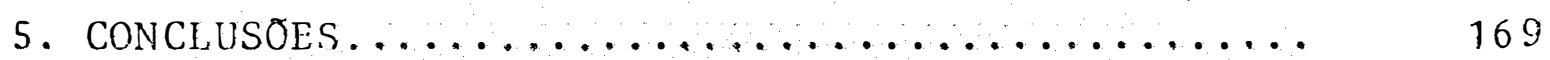

6. Literatura CitadA................... 174

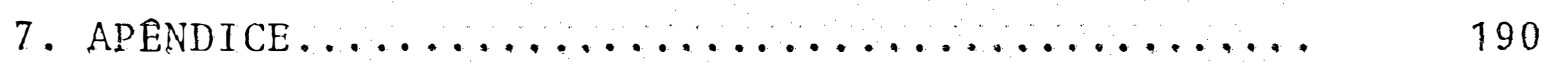


-viii.

\title{
VARIAÇÃO GENETIICA EM PROGENIES DE Eucalyptus saligna SMITH E
}

\section{SUA INTERAÇÃO COM O ESPAÇAMENTO}

\author{
Autor: FERNANDO PATIÑO-VALERA
}

Orientador: PROF. DR. PAULO YOSHIO KAGEYAMA

\section{RESUNo}

O presente trabalho é um estudo da variação ge nética em progênies de meios-irmãos de Eucalyptus saligna Smith, produzidas a partir de sementes colhidas de 169 árvores matrizes crescendo na Area de Coleta de Sementes do Horto Flo restal de Itatinga, São Paulo. Essa populaçäo tem produzido grande parte das sementes comerciais da espëcie utilizadas no Brasil.

O ensaio foi instalado no Parque Florestal "Gua rujā", propriedade do Grupo RIPASA, localizado no município de Avaré, São Paulo, em 28 de fevereiro de 1983. O delineamen to experimental utilizado foi o látice quádruplo com 169 $x$ 13) progênies. Foram utilizadas parcelas lineares de 2.0 plan tas, a um espaçamento inicial de $3,0 \times 1,0 \mathrm{~m}$. O teste foi cir cundado por uma dupla bordadura de plantas das mesmas progê- 
nies.

Aos 17 meses de idade, e visando quantificar a interação genōtipo x espaçámento, foram aplicados desbastes mecânicos na metade de cada parcela para se obter os dois espaçamentos a testar, $3,0 \times 1,0$ e $3,0 \times 2,0 \mathrm{~m}$, nos quais fica ram parcelas com 9 e 5 plantas, respectivamente. Os dois espa çamentos foram considerados como sendo dois experimentos dife rentes.

A avaliação dos testes foi realizada nas idades de 15,26 e 32 meses para as características de altura, diâmetro, área basal e volume cilíndrico de plantas. A idade de 32 meses, foram avaliadas a forma do tronco das árvores e a sobrevivência das plantas.

Os resultados obtidos revelaram variações genê ticas significativas entre progênies para todas as caracterís ticas, em codas as idades e espaçamentos. A forma do tronco $e$ a altura das plantas foram as caracteristicas que revelaram maiores válores de $F$ para as progênies, vindo a seguir o diâmetro, a área basal, o volume cilíndrico c a sobrevivência. Es sas variações genëticas encontradas moitraram resultados homogêneos entre os diferentes espaçamentos e nas diferentes idades dentro des espaçamentos testados.

Para sobrevivência das progênies, foram verifi cadas variações genëticas no espaçamento menor. Contrariamente, para fcrma do tronco, essas variações só foram detectadas no espaçamento $3,0 \times 2,0 \mathrm{~m}$. Esses fatos sugerem que o esp̧aça- 
mento menor aumentou as variaçōes entre progênies quanto à so brevivência e, por outro lado, mascarou a expressão das dife renças para forma do tronco.

Considerando-se os valores de $F$ e as eficiências dos lätices, foi plenamente justificada a utilização do delineamento em lätice para a avaliação dos ensaios de progênies.

As progênies mostraram, aos 17 meses de idade, um valor médio para a densidade bâsica da madeira bastante ex pressivo $\left(0,411 \mathrm{~g} / \mathrm{cm}^{3}\right)$. A variação apresentada pelas progênies, ao nivel de médias de progênies, foi baixa, embora tenham sido encontradas progênies com valores bastante expressi vos para a sua densidade.

Nas anälises da variância conjuntas, envolven do os espaçamentos testados, as características de crescimen to e a forma do tronco, apresentaram variações genéticas significativas ao nível de $1 \%$ para as progênies dentro dos espa çamentos. O efeito do espaçamento apresentou variações significativas ao nível de 1\%, aumentandc dos 26 para os 32 meses, para todas as características, exceto para altura das plantas.

A interação progênies $x$ espaçamento mostrou va lores de F bem pouco expressivos para todas as características. No entanto, quando foi feito o desdobramento da intera ção, os resultados obtidos mostraram, para progênies dentro dos espaçamentos, valores de F significativos ao nível de 1\% para todos os casos, exceto para volume cilíndrico no espaça- 
mento menor. A tendência dos valores de F assim obtidos mostrou a maior expressividade das progênies dentro do espaçamen to mais amplo.

Atravês do coeficiente de correlação de spearman foram obtidas correlações positivas entre os dois espaça mentos, apresentardo valores significativos para as características de crescimento e de forma do tronco. No entanto, es ses valores não foram expressivos e mostraram uma não concordância nas posições relativas das progênies dentro dos espaça mentos, sugerindo a existência de interações progênies $x$ espa çamentos.

Considerando-se a posição relativa quanto à produção em volume por árvore, as progênies foram classifica das nas seguintes categorias: aquelas que reagiram melhor no espaçamento $3, \hat{v} \times 1,0 \mathrm{~m}$; aquelas que reagiram melhor no espa-çamento $3,0 \times 2,0 \mathrm{~m}$; e aquelas que apresentaram um desenvolvi mento semclhante en ambos os espaçamentos.

As variâncias genéticas entre progênies, estimadas para todas as caracteristicas, mostraram boas precisões a julgar pelos baixos valores dos desvios padrões encontrados. Os coeficientes de herdabilidade no sentido restrito e ao njvel de plantas variaram tanto entre os espaçamentos, testados, como entre is características consideradas, quando comparadas as diferentes idades nos dois delineamentos utilizados. Esses coeficientes de herdabilidade apresentaram a tendência de decrescer com a idade. 
Para as anālises conjuntas envolvendo os dois espaçamentos, os coeficientés de herdabilidade apresentaram a mesma tendência observada nas anālises individuais, apresentando sempre valores mais próximos daqueles obtidos para o es paçamento mais amplo.

A relação entre os coeficientes de variação ge nética e experimental, utilizada como indicadora das possibilidades de sucesso na seleção dentro dos ensaios, mostrou va lores muito estảveis para cada característica, com ligeira vantagem à idade de 15 meses. Esse coeficiente acompanhou a tendência dns coeficientes de herdabilidade para as características consideradas.

As relações entre as variâncias dentro de par celas e genëtica entre progênies $\left(\sigma_{\mathrm{d}}^{2} / \sigma_{\mathrm{p}}^{2}\right)$ apresentaram valores confirmando que as progênies de Eucalyptus saligna Smith apre sentam características pröprias de plantas alógamas.

As correlações genêticas aditivas ao nível de plantas $€$ as correlações fenotípicas ao nível de médias de fa mílias apresentaram valores positivos e próximos à unidade, mostrando o reflexo de uma caracteristica sobre a outra quando se pratica a seleção para urna delas, e a pouca interferân cia ambiental na mudança dos dois tipos de correlação estuda dos, respecivamente. 
.xii.

\title{
GENETIC VARIABILITY IN PROGENIES OF Eucalyptus saligna SMITH AND THE SPACIMG $\times$ GENOTYPE INTERACTIONS
}

\author{
Author : FERNANDO PATIÑO-VALERA \\ Adviser: DR. PAULO YOSHIO KAGEYAMA
}

\section{SURAMARY}

The genetic variation in open pollinated proge nies of Eucalyptus saligna Smith produced from seeds collected from 169 mother-trees growing in the Seed Collection Area in the Forestry Park of Itatinga, State of São Paulo, Brazil, was studied

For this, a trial was established of February 28, 1983, il the "Guaruja" Forestry Park, owned by the RIPASA Group, located in the Municipality of Avaré, State of São Pau 10, Brazil. The experimental design utilized was the quadruple lattice, with $169(13 \times 13)$ progenies. Linear plots con sisting of 20 plants were used and the $3.0 \times 1.0 \mathrm{~m}$ spacing was used initially. The trial was surrounded by two rows of seedlings form the same progenies utilized in the trial.

$$
\text { At the age of } 17 \text { months, a mechanical clear }
$$


cutting was made with the main objective of obtaining the two spacings to be tested $(3.0 \times 1.0 \mathrm{~m}$ and $3.0 \times 2.0 \mathrm{~m}$, with 9 and 5 plants per plot, respectively), and for evaluating the spacing $x$ genotype interaction. The two spacings resulting from the clear cutting operations were considered to be two different trials.

The evaluation of the trials was conducted at the ages of 15,26 , and 32 months, for height growth, diameter growth, basal area, and cylindric volume. At 32 months, tree stem form and plant survival were also evaluated.

The results obtained at 32 months revealed con siderable genetic variation for all growth characteristics studied, at all ages and spacings considered. Stem form and plant height were the most variable characteristics, showing the highest values for F, followed ky diameter, basal area, volume and plant survival. The genetic variations detected for different spacings and ages, within the spacings under test, were shown to be very homogeneous.

For plant survival, genetic variations were de tected in the $3.0 \times 1.0 \mathrm{~m}$ spacing. Reversely, for stem form, variations were detected only in the wider spacing. These facts suggest that the lower spacing increased the variations among progenies for survival while for stem form, it masked the expression of differences.

Considering the $F$ values and the efficiencies of the lattices, the utilization of lattice experimental de- 
sign for evaluating progeny trials is fully justified.

At the age of 17 months the progenies showed an average value for specific gravity considered to be very expressive $\left(0.411 \mathrm{~g} / \mathrm{cm}^{3}\right)$. The variation shown for the progenies at the progeny mean level was very low. However, some pro genies with very expressive specific gravity values werefound.

The joint analysis for spacings showed genetic variation among progenies for all growth characteristics and stem form. The F values revealed significant genetic variation for the progenies within spacing at the 1\% level. On the 0 ther hand, the spacing effect increased expressively from 26 to 32 months of age for all characteristics except plant height. The interaction between progenies and spacing showed very low F values for all characteristics. However when the joint analysis was broken down, the results showed sigili ficant values at the $1 \%$ level for the progenies within the spacing, for all characteristics except volume at the $3.0 \mathrm{x}$ $1.0 \mathrm{~m}$ spacing. The $\mathrm{F}$ values obtained were more expressive for all characteristics in the wider spacing.

Positive correlations between the two spacings were obtained through Spearman's confficient of correlation, where significant values were found growth characteristics and stem form. However, these values were not expressive and are in disagreement with the relative positions of the progenies within spacings. thus suggesting the possibility of the presente of spacing $x$ genotype interactions in the trials. 
Taking into account the relative position of progenies for volume production in each of the spacings, the progenies were classified in the following categories: progenies with the best volume growth in the $3.0 \times 1.0 \mathrm{~m}$ spacing; progenies with the best volume growth in the $3.0 \times 2.0 \mathrm{~m} \mathrm{spa-}$ cing; and, progenies with similar volume growth in both spacings .

The genetic variances among progenies, estima ted for all characteristics, showed good precision, considering the low standard deviations obtained. The narrow sense heritabilities at plant level showed variability among the spacings tested and among the characteristics studied for differente ages and in both experimental designs utilized. These coefficientes of heritability also show the general tendency of decreasing their values with age, in both spacings and experimental designs utilized.

In the joint analysis involving the two spacings, the heritability coefficients revealed the same tenden cy as in the individual analysis, showing values closer to those obtained for the wider spacing.

The relationship between coefficients of gere tic variation and experimental variation utilized as an indicator for evaluatin the possibility of successful genetic gain through selection, and for identifying the most suitable condition for practicing selection within trials, shows very sta ble values for all characteristics sith a slight advantage for 
15 months of age. These coefficients followed the same tenden cy observed in the heritability coefficients.

The relationship between phenotypic variation within progenies and genetic variation among progenies $\left(\sigma_{\mathrm{d}}^{2} /\right.$ $\sigma_{\mathrm{p}}^{2}$ ), utilized for determining the mating system of the progenies, confirms that the progenies are preferably cross-pollinating .

The genetic correlations at plant level, and the phenotypic correlations at the family mean level showed positive and near to 1 values, showing the influence of one characteristic over another when selection is practiced, anc the minor environmental influence in both of the correlation types studied, respectively. 


\section{INTRODUCÃO}

O reflorestamento é, de fato, uma importante atividade dentro da economia do Brasil e de muitos outros países do mundo, quer pelo fornecimento de matéria prima pa ra as indústrias de celulose e papel, chapas de fibra e side rurgia, ben como uma das alternativas energéticas para suprir a esrassez de petróleo e de outros combustíveis fósseis. Por outro lado, e importante se considerar que essas industrias requerem cada vez mais matêria prima com certos padrões de qualidade e uniformidade, para se obter produtos da methor qualidade possível.

A moderna silvicultura baseia-se no cultivo intensivo de povoamentos estabelecidos a partir, principalmente, de espécies exóticas, destacando-se as dos gêneros $\underline{E}$ calyptus e Pinus, objetivando a condução racional e organiza 
da dessas florestas implantadas, para se obter a máxima prọ dução sustentada de madeirá ou de outros produtos, da maior qualidade e a custos mais baixos possiveis.

Dentre as espécies de Eucalyptus mais amplamente utilizadas no Brasil, destacam-se E. grandis Hill ex Maiden, E. saligna Smith e E. urophylla E T Blake. Essas es pécies estudadas por diversos autores apresentam uma alta po tencialidade pelas suas condições de adaptação a diversas con dições. O E. saligna Smith tem sido pouco estudado do ponto de vista genético em nossas condições, considerando-se muito importante conhecer o potencial genético da população base de Itatinga-SP, que tem produzido grande parte das sementes comerciais da espécie utilizadas no Brasil.

A produtividade florestal $\vec{e}$ influenciada por vârios parâmetros, dentre os quais cs mais relevantes estão relacionados à qualidade genética do material reprodutivo a empregar, aos espaçamentos compatíveis com o uso final da ma deira.e, logicamente, à idade de corte e às prảticas silvìculturais que permitam o adequado desenvolvimento dos povoa mentos.

O espaçamento tem uma sêric de implicações do ponto de vista silvicultural, tecnológico e econômico. Ele influencia as taxas de crescimento das plantas, a qualidadé da madeira, a idade de corte, bem como as präticas de exploração e manejo florestal e, consequentemente, os custos de produção. 
o uso final da madeira é um fator muito impor tante na seleção dos espaçamentos, já que se considera que o espaçamento ideal para celulose e/ou chapas de fibra não é o mesmo indicado para a produção de lenha, carvão ou madeira para serraria. Ainda, a diferenciação entre espaçamentos po de ocorrer a nível de espécies, procedência e progênies.

As técnicas de manejo intensivo aliadas ao me 1horamento genético têm propiciado incrementos significativos tanto na produção volumétrica de madeira por unidade de superfície como da qualidade da mesmia, para muitas espécies florestais.

Conforme o melhoramento florestal progride e utiliza gerações avançadas de melhoramento, todas as operações de pesquisa tornam-se mais caras e os riscos no estabe lecimento d’s povoamentos são incrementados, com o afunilamento da base genética. E muito importante, portanto, avaliar criticamente os genótipos a serem utilizados dentro desses programas de melhoramento. Os fenōtjpos dessas árvores podem ser influenciados positiva ou negativamente pelo ambiente no qual eles crescem e competem, geranco-se interações de genótipos $x$ ambientes.

Para o melhorista, as muitas definições estą tísticas da incteração genótipo $x$ amíiente podem ser reduzidas a uma implicação prática: a melìor população ou indivíduo num "site" não é necessariamente a melhor para outros "sites". 
o nível, ao qual os efeitos da interação genọ tipo $x$ ambiente são importantes, varia com a espécie, proce dência, progênie ou clone, e com a característica considerada. Quando ignorados os efeitos da interação, podem-se produ zir perdas muito grandes na produção dos povoamentos, seja pela morte das árvores ou pela redução do crescimento, ou ainda, por ambas as causas.

Atualmente, dentro do melhoramento genético e quando utilizada a estratégia de multipopulações, é possível manter a existência e identidade de vários complexos de genes, sendo que essas populações são altamente produtivas pa ra ambientes específicos, permitindo, dessa forma, evitar ao máximo a endogamia, e propiciando que essas populações sejam geneticamente divergentes, mantendo-se assim a sua variabili dade e assegurando ganhos futuros a um custo menor. Essas po pulações divergentes poảem ser combinadas entre si mais tarde para regenerar a variação dos materiais genéticos utiliza dos no prugrama de melhoramento.

A pesquisa em silvicultura e em melhoramento tradicionalmente têm sido conduzidas separadamente, porëm, con siderando os avanços obtidos em ambas as especialidades, com técnicas silviculturais sofisticadas e a utilizaçã de multi populações dentro dos programas de melhoramento, é muito im portante insegrä-las para que em forma conjunta sejam determinados os melhores genôtipos para cada șistema de manejo e para cada um dos "sites" onde serão estabelecidos os povoa- 
mentos.

O teste de progênies de Eucalyptus saligna Smith, que vem sendo conduzido pela Companhia Reflorestadora Nacional do grupo RIPASA, e motivo deste estudo, faz parte de um programa de melhoramento genético que vem sendo conduzido com a espécie.

Baseado no potencial e a importância atual da espécie, e os poucos trabalhos sobre o tema, considerou- se muito importante conhecer o potencial genético da população de Itatinga desta espécie, visando ao seu melhoramento genético e a sua potencialidade, considerando-se o seu comporta mento face a um dos tratamentos silviculturais, mais importante, o espaçamento, com vistas à produção de materiais pa ra celulose, lenha e carvão.

O trabalho envolve dois assuntos por demais complexos e amplos: progênies e espaçamentos, visando conhecer a interação entre ambos. Assim, os objetivos que se pie tendeu atingir foram:

(a) Determinar a magnitude e os padrões da va riação genética entre e dentro das progênies, para as princi pais características silviculturais (altura, diâmetro, área basal e volume cilindrico), e para forma do tronco das ärvo res da populaçäo de Eucalyptus saligna Smith - Itatinga-SP.

(b) Quantificar a interação genötipo $x$ espaçą mento para as progênies de Eucalyptus saligna Smith. 
.6 .

\section{REVISÃO DE LITERATURA}

\subsection{Efeitos do Espaçamento entre Plantas}

O espaçamento tem uma série de implicações do ponto de vista silvicultural, tecnológico e econômico. Ele a feta as taxas de crescimento das plantas, a qualidade da ma deira, a idade de corte, bem como as práticas de exploração e manejo florestal e, consequentemerte, os custos de produção (BALLONI e SIMÖES, 1980).

SILVA (1984) cita que até recentemente as ati vidades de reflorestamento no Brasil tinham padrões clássicos e rígidos $\leqslant$ que o espaçamento mais utilizado era de 3,0 x $2,0 \mathrm{~m}$, com ciclo de 21 anos em 3 cortes, e utilizando-se ba sicamente de duas espécies: Eucalyptus grandis Hill Ex Maiden e E. saligna Smith. 
BALLONI e SIMOES (1980) relatam que a escolha do espaçamento de plantio na maioria dos planejamentos florestais tem-se fundamentado simplesmente no uso final da ma deira; negligenciou-se outros envolvimentos ecológicos e/ou silviculturais de suma importância.

SMITH (1962) afirma que em povoamentos mais densos pode-se obter um maior volume de madeira e que as ârvores dentro deles atingem mais cedo a plena ocupação do es paço disponîvel. Porém, deve-se procurar a obtenção da produ ção ótima em termos não somente volumétricos, mas sim também de material utilizävel.

SILVA (1984) comenta que o espaçamento das es pécies florestais não deve ser rígido para cada espécie ou local; considerações especiais devem ser feitas quanto ao 1o cal, häbito de crescimento da espécíe, sobrevivência espera da, finalidade de produção, futuros tratos culturais, tipos de equipamentos a serem empregados nos cortes e remoção da madeira e estudos comparativos envolvendo a economia e o con dimento.

O autor citado salienta que o espaçamento tem influência sobre as características de crescimento das espécies (altura e diâmetro), influenciando, consequentemente, a produção em volume, a idade de corte e as präticas culturais a serem aplicadas nos povoamentos; o espaçamento também serả função do "site", da espécie e possivelmente da qualidade ge nética do material reprodutivo a ser utilizado. 
BALLONI e SIMÓES (1980) citam que, durante o crescimento inicial da floresta, o principal fator de compe tição é a erva daninha, cujo controle é feito pelos tratos culturais. Posteriormente, conforme as ärvores vão-se desen volvendo, inicia-se uma forte competição por luz, água e nu trientes.

A competição por luz, umidade e nutrientes de pende grandemente da quantidade de troncos por unidade de $\vec{a}-$ rea. A combinação de fatores do meio ambiente e genéticos faz com que o desenvolvimento das copas seja bastante intenso, promovendo a competição; em povoamentos equianos a competi-ção entre as copas é mais intensa do çue a compețição entre as raizes (DANIEL et alii, 1982).

Normalmente, as ärvores mais vigorosas tendem a aumentar anualmente suas alturas, o tamanho do tronco, o comprimento dos ramos e o nümero de folhas. Portanto, exigem um aumento continuo de espaço para garantir a sua sobreviven cia e manifestar suas condições vitais. Essas árvores mais vigorosas e mais adaptadas sobrepujarão as menos adaptadas.

Segundo Hillis e Brown (1978), citados por BAL LONI e SIMOES (1980), a maioria das espëcies de Eucalyptus de rápido crescimento são intolerantes à competição, ocorren do durante o seu crescimento uma räpica segregação do talhão em estratos (dominante, codominante e dominado). O tempo pá ra a definição dos estratos estará em função do espaçamento, da espécie e da qualidade do "site", como tambëm da variação 
genêtica na população e de uma interação entre estes fatores. BALLONI e SIMOES (1980) mostraram que o Eucalyptus saligna Smith apresenta, jâ a uma idade de 6 anos e 2 meses, maiores percentagens de falhas, mortes e ārvores domi nadas em espaçamentos mais apertados $(3,0 \times 1,50 \mathrm{~m}$ e $3,0 \mathrm{x}$ 2,0 m), quando comparado com o E. grandis Hill Ex Maiden (ta bela 1).

Tabela 1 - Proporção de ärvores dominadas, falhas e mortas em parcelas experimentais de $E$. grandis Hill Ex Maiden e $E$. saligna Smith, aos 6 anos e 2 meses de idade, sob diferentes espaçamentos.

\begin{tabular}{|c|c|c|c|c|c|c|c|}
\hline $\begin{array}{c}\text { Espaça- } \\
\text { mento } \\
\text { (m) }\end{array}$ & $\begin{array}{l}\text { Surper- } \\
\text { fície } \\
\mathrm{m}^{2}\end{array}$ & $\begin{array}{l}\text { E. grandi } \\
\text { \% Falhas } \\
\text { e mortas }\end{array}$ & $\begin{array}{l}\text { Hill E: } \\
: \text { Doini. } \\
\text { nadas }\end{array}$ & $\begin{array}{l}\text { Maiden } \\
\text { Total }\end{array}$ & 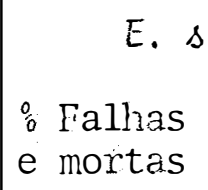 & $\begin{array}{l}\text { aligna: } \\
\text { : Donil } \\
\text { nadas }\end{array}$ & $\begin{array}{l}\text { th } \\
\text { Total }\end{array}$ \\
\hline $3,0 \times 1,50$ & 4,5 & 16 & 15 & 31 & 21 & 30 & 51 \\
\hline $3,0 \times 2,00$ & 6,0 & 18 & 6 & 24 & 21 & 20 & 41 \\
\hline $3,0 \times 2,50$ & 7,5 & 15 & 9 & 24 & 11 & 12 & 23 \\
\hline $3,0 \times 3,75$ & 11,25 & 19 & 12 & $3 i$ & 11 & 16 & 28 \\
\hline
\end{tabular}

Fonte: BALLONI e SIMOES (1980).

Os autores concluem que esses dados, apeśar de não serem conclusivos, mostram claramente que o plantio de E. saligna em espaçamentos inferiores a $3,0 \times 2,0 \mathrm{~m}$ deve ser encarado com cautela para rotações convencionais, ou seja, o 
corte com 6 a 7 anos de idade.

SIMOES et alii (1981) recomendam como espaçamento ideal para o Eucalyptus saligna Smith aquele que permi ta uma superfície de 6,0 a 7,5 metros quadrados por planta, possibilitando a sobrevivência de ärvores na segunda rotação.

GUIMARAES (1965) verificou para o $E$. saligna

Smith aos 8 anos de idade, que existe uma tendência para au mentar a mortalidade das ärvores à medida que os espaços di minuem. No caso do espaçamento $1,0 \times 1,0$ obteve-se uma morta lidade de $65,9 \%$; para $02,0 \times 2,0 \mathrm{~m}$ atingiu $60,76 \%$ de morta lidade. Entretanto, para 1,50 x 3,00 m obteve-se 49,16\% de mortalidade e para o espaçamento $3,00 \times 2,00 \mathrm{~m}$, uma taxa de 44,63\% de mortalidade. TEIXEIRA e RAUEN (1973) relatam, para um teste de progênies de $E$. saligna Smith instalado no Rjo Grande do Sul, sobrevivências mínimas de 65\% e máximas de 95\% (mëdia de 81\%), em espaçamentos de $3,0 \times 2,0 \mathrm{~m}$ e a uma $\dot{i}$ dade de 2 anos e 10 meses.

A conicidade do fuste é uma caracterîstica que pode ser influenciada pelo espaçamento e que tem influêncis na produção real de madeira, conforme relato de vârios autores.

Larson (1962), citado por DANIEL et alii(1982), indica que, tronco das ârvores tem una forma muito complexa e que é função da espēcie e das características da copa. Nas coníferas, quando as árvores crescem dentro dos talhões, on de a proporção da copa viva é relativamente pequena, as mes 
mas terão fustes mais cilindricos que aquelas que se desenvolvem isoladamente e cuja copa de maior tamanho influi para que o tronco seja mais cônico. Mostra ainda que os desbastes fazem com que as ârvores remanescentes sejam mais cônicas, já que o tratamențo aumenta a proporção da copa viva; por outro lado, as podas fazem que os troncos fiquem menos cônicos. 0 grau de mudança potencial na forma do tronco dependerá da in tensidade dos tratamentos de poda e desbaste e da magnitude das mudanças por eles produzidas sobre a taxa de crescimento das ärvores.

Montagna et alii (1973), citados por SILVA (1984), afirmam que a partir de um certo nümero de plantas por hectare hâ uma tendência do aumento da conicidade con o aumento do espaçamento.

VAN LAAR (1978) relata que para Pinus patula

Sch1 et cham.o fator de forma diminuiu com o aumento do espa çamento, variando de $0,477 \mathrm{com} 902$ ärvores por hectare, atê 0,437 quando o povoamento tinha scmente 124 ârvores por hectare. A alteração assinalada diminuiu em quase $10 \%$ volume real de madeira.

De forma geral, pode-se concluir que os espa çamentos mais largos têm proporcionado fatores de forma mais baixos.

BALLONI e SIMOES (19300) ressaltaram que existem inúmeras controvérsias com relação à influência do espạ çamento sobre o crescimento em altura das árvores. Relatam 
os autores que existem casos onde a altura mëdia aumenta com - espaçamento e outros ondé o resultado $\vec{e}$ inverso, afirmando que nos espaçamentos muito fechados, a altura média diminui, em função do grande nümero de ärvores dominadas.

MESKIMEN e FRANKLIN (1978), trabalhando com

Eucalyptus grandis Hill Ex Maidên em quatro espaçamentos di ferentes, verificaram que à idade de 7 anos e 3 meses nãohou ve diferenças na altura mêdia das ârvores, enquanto que o diâmetro foi diretamente influenciado pela redução do espaçą mento.

Por sua vez, PEREIRA et alie (1982) verifica ram para E. grandis Hill Ex Maiden, que a altura do povoamen to foi influenciada pelo nümexo de plantas por hectare. Os autores, comparando os espaçamentos de $3,0 \times 1,0$ e o de 3,0 $x 2,0 \mathrm{~m}$, afirmam que hâa um ganho de aproximadamente $13 \%$ em altura, em favor do menor espaçamento. CouTo (1977), em estu do de 5 diferentes espaçamentos para Eucalyptus urophylla S. T. Blake, at $\hat{e}$ a idade de 93 meses, verificou que a altura me dia e o diämetro mêdio do povoamento aumentaram com o aumento do espaçamento.

Muitos autores têm verificado a existência de uma tendência em aumentar o crescimento em altura, à medida que se aumenta o nümero de plantas por hectare. 0 anterior pode-se explicar em função de que nos espaçamentos mais redu zidos, a competição entre plantas em busca de luz $\widehat{e}$ muito mais intensa em função da necessidade da ärvore de ampliar 
ao máximo a superfície foliar e cobrir sua necessidade de uma normal assimilação clorófiliana, estimulando-se, dessa for ma, o crescimento em altura.

Por sua vez, SMITH (1962) e DANIEL et alii (1982) comentam que algumas das funções fisiológicas que se processam na ärvore são mais crïticas a sua sobrevivência do que outras, existindo, dessa forma, uma "priorização natural" quanto ao consumo de alimentos produzidos pela árvore. Assim, ainda que o diâmetro represente um suporte para a copa da ärvore, o. crescimento em diâmetro não parece possuir um valor muito grande para a sobrevivência da ärvore, no sen tido de que possa comandar alta prioridade no consumo de ali mentos. Assin, continua o autor, o diâmetro $\overrightarrow{\mathrm{e}}$. prontamente controlável pelo espaçamento ou por qualquer outro método de controle da densidade populacional.

KAGEYAMA (1986), citando Budowski (1965), co menta que as espécies arböreas das florestas tropicais podem ser divididas em quatro grupos disintos: a) pioneiras; b) secundārias iniciais; c) secundärias tardias e d) climaxes, considerando ainda, o autor, que essa seria então a sequência da sucossão que orientaria o desenvolvimento da floresta a partir de un distūrbio da mesma.

KAGEYAMA e PATIÑO (1935) ressaltam o fato de que a grande maioria das espêcies utilizadas no mundo, dentro de programas de reflorestamento, são espêcies pioneiras ou secundárias, destacando-se as espécies dos gêneros Euca- 
lyptus, Pinus, Gmelina e Tectona, dentre outros.

Por sua vez, KAGEYAMA (1986) comenta que a avaliação de experimentos de espaçamentos de espécies nativas e de espécies de Eucalyptus mostra claramente uma tendência para a classificação das espécies quanto a sua resposta a maior ou menor quantidade de luz: O autor levanta que existe uma gradação de respostas, desde aquelas espécies que apresentam grandes incrementos de crescimento com o aumento do espaçamento, até o outro extremo onde ocorre uma resposta ne gativa no crescimento quando se aumenta o espaçamento. 0 au tor comenta que a interpretação dessas respostas diferenciais pode ser feita considerando as exigências de luz das plantas em função do decorrer da sucessão. Assim, quanto maior a res posta à abertura do espaço, em termos de crescimento princí palmente em altura, maior seria a proximidade da fase inicial da sucessão, ou das espécies pioneiras. Pelo lado opos to, quanto maior a resposta positiva em crescimento com a di minuição ùa luz, maior proximidade das espécies clímax, ou fase final da sucessäo.

KAGEYAMA (1986) salienta que quando comparados os ensaios de espaçamentos envolvendo nativas com aquie les de espécies de Eucalyptus, as tendências observadas são semelhantes às verificadas. O autor comenta que apesar das espëcies de Eucalıptus terem um comportamento mais tipicamen te de pioneiras, algumas espécies mostram maior efeito em re lação ao espaçamento do que outras, revelando que mesmo as 
espêcies de Eucalyptus não sao homogêneas quanto a esse as-pecto.

BALLONI e SIMOES (1980) verificaram uma ten dência para diminuir a altura mêdia das ârvores de Eucalyptus grandis Hill Ex Maiden e E. saligna Smith, à medida que se diminuía o espaçamento. Entretanto, a altura mêdia de $15 \%$ das ärvores dominantes das parcelas não sofreu alterações significativas para ambas as espécies; os autores reportam que pa ram o Eucalyptus saligna Snith aos 74 meses de idade as ärvo res atingiram as alturas que podem ser observadas na tabela 2 .

Tabela 2 - Altura mëdia de Eucalyptus saligna Smith, aos 74 meses de ida de, em diferentes espaçamentos.

\begin{tabular}{ccccc}
\hline $\begin{array}{c}\text { Espaçamento } \\
(\mathrm{m})\end{array}$ & $\begin{array}{c}\text { Superficie } \\
\left(\mathrm{m}^{2}\right)\end{array}$ & $\begin{array}{c}\text { Altura } \\
(\mathrm{m})\end{array}$ & $\begin{array}{c}\text { Coef. Var. } \\
\left(\begin{array}{l}0 \\
0\end{array}\right)\end{array}$ & $\begin{array}{c}\text { Altura } \\
\text { dominante }(\mathrm{m})\end{array}$ \\
\hline $3,0 \times 1,50$ & 4,5 & 16,9 & 32 & 24,6 \\
$3,0 \times 2,00$ & 6,0 & 18,3 & 31 & 24,3 \\
$3,0 \times 2,50$ & 7,5 & 19,2 & 23 & 24,8 \\
$3,0 \times 3,75$ & 11,25 & 19,4 & 26 & $.24,7$ \\
\hline
\end{tabular}

Fonte: BALLONI e SIMOES (1980). 
REZENDE et alii (1980), num experimento sobre espaçamentos para Eucalyptús grandis Hill Ex Maiden (Procedência: Zimbabwe) e Eucalyptus saligna Smith (Procedência: I tatinga, SP), a uma idade de dois anos, indicaram que para E. saligna Smith o espaçamento afetou significativamente o diâmetro e o volume, não existinđo diferenças significativas para a altura e a percentagem de sobrevivência. O maior volu me foi obtido no espaçamento de $(1,0 \times 1,0) \times 3,0 \mathrm{~m}$, onde fo ram plantadas 5.000 ärvores por hectare; o nenox volume foi encontrado nas parcelas testemunhas $(3,0 \times 2,0 \mathrm{~m})$, onde foram plantadas 1.667 ärvores por hectaxe. Quanto ao diâmetro, o maior crescimento foi obtido nos espaçamentos de 3,0 x 2,0 $m$ e os menores diâmetros nos espaçamentos de $(1,0 \times 1,0) x$ $3,0 \mathrm{~m}$ e $(1,0 \times 1,5) \times 3,0 \mathrm{~m}$, o que pode indicax a má resposta do E. saligna Smith a uma forte competição.

Esses autores concluiram que: (a) o maior cres cimento volımétrico foi obtido nos menores espaçamentos; (b) para o E. saligna Smith o espaçamento afetou o crescimentio em volume e diâmetro, não afetando as alturas; e (c) sem con siderar os aspectos econômicos, o espaçamento $(1,0 \times 1,0) \quad x$ 3,0 m revelou-se o melhor para ambas as espëcies.

COELHO et alii (1970), em experimento conduzi do com 4 espécies, 2 espaçamentos e 4 ëpocas de corte, encon traram que os espaçamentos tiveram ação positiva sobre o cres cimento em diâmetro das ârvores, não influenciando, porẻm, o crescimento em altura aos quatro anos de idade para Eucalyp 
tus saligna Smith, E. alba. Reinw e E. propinqua Deane. Embo ra os autores salientem qué os espaçamentos influiram posití vamente sobre o crescimento em diâmetro e altura do Eucalyg tus grandis Hill Ex Maiden no espaçamento de $3,0 \times 2,0 \mathrm{~m}$, os autores concluem que finalmente existindo uma correlação entre diâmetro e altura, o espaçamento mais amplo, favorecendo o crescimento em diâmetro, concorre também para maior altura das ārvores, do que resulta uma altura média mais elevada.

Quanto ao volume, BALLONI e SIMÕES (1980) sa lientam que: a altura, o diâmetro (DAP), a sobrevivência e a conicidade do fuste são características que podem ser altera das pelo espaçamento de plantio e que interferem tanto no vo lume total de madeira como no volume util produzido pela flo resta.

GUIMARAES (1960) releta para o caso de Euca-: lyptus saligna Smith, que hä una certa tendência em aumentar a produção de lenha quando diminui o espaçamento. Em ensaio. de espaçamento estabelecido no Horto de Aimorês, o autor ck teve as proluçöes médias de lenha em função do espaçamento, como pode se observar na tabela 3 , a seguir. 
Tabela 3 - Produção de lenha em função do espaçamento em Eucalusptus saligna Smith, aos 8 anos de idade.

\begin{tabular}{ccc|ccc}
\hline $\begin{array}{c}\text { Espaça- } \\
\text { mento } \\
(\mathrm{m})\end{array}$ & $\begin{array}{c}\text { Super- } \\
\text { ficie } \\
\left(\mathrm{m}^{2}\right)\end{array}$ & $\begin{array}{c}\text { Produção de } \\
\text { 1enha } \\
\left(\mathrm{m}^{3} / \mathrm{ha}\right)\end{array}$ & $\begin{array}{c}\text { Espaça- } \\
\text { mento } \\
(\mathrm{m})\end{array}$ & $\begin{array}{c}\text { Super- } \\
\text { fície } \\
\left(\mathrm{m}^{2}\right)\end{array}$ & $\begin{array}{c}\text { Produção de } \\
\text { 1enha } \\
\left(\mathrm{m}^{3} / \mathrm{ha}\right)\end{array}$ \\
\hline $1,0 \times 1,0$ & 1,00 & 267,50 & $1,5 \times 2,5$ & 3,75 & 229,50 \\
$1,0 \times 1,5$ & 1,50 & 261,75 & $2,0 \times 2,0$ & 4,00 & 246,75 \\
$1,0 \times 2,0$ & 2,00 & 266,00 & $1,5 \times 3,0$ & 4,50 & 224,75 \\
$1,5 \times 1,5$ & 2,25 & 243,00 & $2,0 \times 2,5$ & 5,00 & 213,25 \\
$1,5 \times 2,0$ & 3,00 & 253,25 & $2,0 \times 3,0$ & 6,00 & 206,00 \\
$1,0 \times 3,0$ & 3,00 & 229,25 & & & \\
\hline
\end{tabular}

Fonte: GUIMARÃES (1960).

COUTO (1977), estudando o comportamento do $E \underline{u}$ calyptus urophylla S.T.Blake em diferentes espaçamentos e di ferentes idades, verificou que a ârea basal média e o volume mëdio por hectare diminuiram com o aumento do espaçamento. Por sua vez, MESKIMEN e FRANKLIN (1978) indicaram que para E. grandis, à idade de 7 anos e 3 meses, o volume mëdio foi inversamente influenciado pela redução do espaçamento.

BALLONI e SIMOES (1980) afirman que os povnamentos mais densos produzem maior volume de madeira que aque les menos densos. Por outro lado, os espaçamentos maiores pro duzem um nümero maior de ârvores com maior volune individual. Ainda que nos povoamentos com maior nümero de ârvores, a produção volumétrica total seja maior, o volume ütil pode 
não sofrer alteraçōes, produzindo-se una maior quantidade de materiais finos.

$$
\text { Van Laar (1961), citado por BALLONI et aiii }
$$

(1980) e considerando como volume ütiI aquele produzido por ärvores com diâmetro acima de $7,6 \mathrm{~cm}$, observou para Eucalyptus saligna Smith, que o volume ütil das ärvores dominadas, diminuiu-se com o acréscimo de árvores por hectare, enquanto que o volume útil das classes intermediārias não foi alterado. Por outro lado, o volume ütil das árvores dominantes aumentol: com a diminuição do espaçamento de plantio.

Segundo BALLONI et alii (1980), esses dados mostram que a adoção de espaçamentos não adequados para uma certa espécie pode resultar em um numero excessivo de ärvores dominadas, as quais influem negativamente no volume ütil. e possivelmente no volume total.

\subsection{Interaç̃̃o Genôtifo X Ambiente}

SHELBOURNE (1972) define a interação genótìn $x$ ambiente como a variação entre genôtipos em sua resposta a diferentes condições ambientais. Por sua vez, MAZHESON (1978) indica que $a$ interação genötipo $x$ ambiente é a atuação conjunta dos genótipos e dos ambientes. Da mesma forma, QUIJADA (1980) define a interaçäo genötipo $x$ ambiente como sendo a 
falta de uniformidade na resposta de dojs ou mais grupos de plantas em dois ou mais ambientes.

MORGENSTERN (1982) mostra que as interações entre genótipos "site" e tratos silviculturais podem tomar muitas formas e incluir muitos organismos. Em geral, continua o autor, interação significa influências mütuas e elas podem incluir: competição entre genôtipos, interações entre genótipos e fatores do ambiente, agentes biôticos e, ainda, os efeitos dos tratos silviculturais.

Usa-se a palavra ambiente para definir uma cex ta combinação de fatores edäficos, kiôticos, climäticos, em que se desenvolve uma certa espécie florestal e que influenciam o seu crescimento, aliada aos tratos culturais e condi ções de estabelecimento necessärios para atingir um bom desenvolvimento e, consequentemente, uma boa produtividade.

FONSECA (1979) ilustra graficamente a intera ção genótipo x local, pela variaçäo das respostas dos genóti pos a diferentes ambientes. O autcr, considerando as diferen tes alternativas do teste $F$ e supondo dojs genötipos ( $A$ e B) testados em dois locais, apresentou quatro situações poss $\vec{i} \cdots$ veis, as n!ais podem ser representadas esquematicamente como a seguir: 

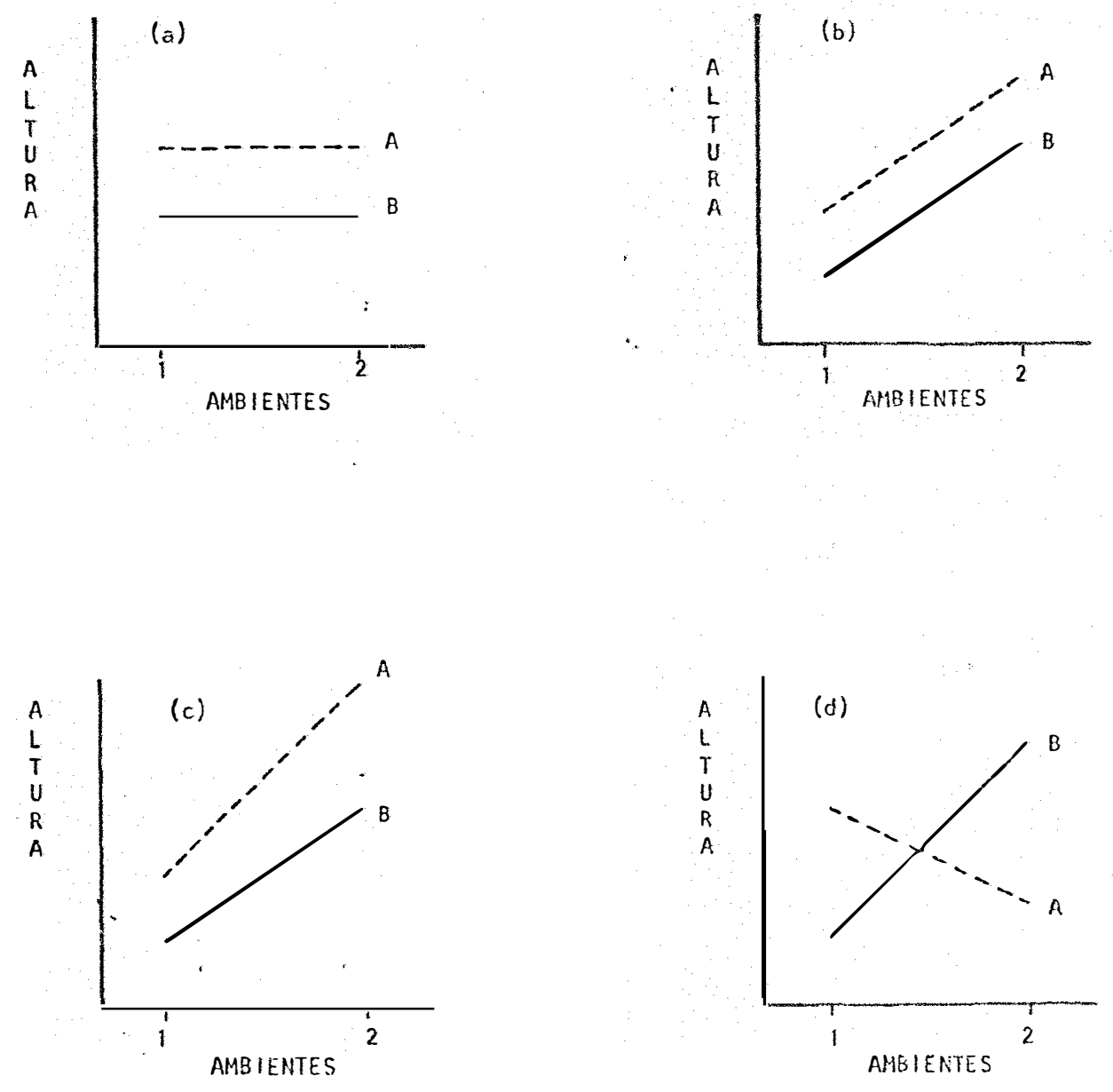

Figura 1 - Situações possîveis da interação genōtipo x ambiente, segurıdo FONSECA (1979).

No primeiro caso, observa-se que o comportamento de ambos os genótipos foi o mesmo nos dois ambientes estudados, sendo que sempre o material "A" foi superior ao "B". No caso b, verifica-se que ambos os genótipos apresentaram uma melhor produção no ambiente 2 en relação ao 1 , per 
manecendo a mesma diferença e posição entre eles em ambos os locais. No caso c, observa-se que o genötipo "A" é superior ao genótipo "B" e que ambos melhoraram de comportamento no ambiente 2, porém, o ambiente 2 foi muito mais favorâvel ao genötipo "A" do que ao genótipo "B". O autor relata que esse tipo de interação recebe a denominação de interação simples. No ûltimo caso, os genótipos comportam-se de maneira diferen te em cada ambiente, ainda que o genötipo "B" seja superior ao "A", considerando conjuntamente os dois locais. Maiores ganhos para a caracteristica considerada sexiam obtidos se no ambiente 1 for utilizado o genôtipo "A" e no ambiente 2 o genótipo "B". Segundo o autor, esse tipo de interação recebe a denominação de interação complexa. Este ültimo tipo de in t.eração tambẻm foi esquematizado na mesma forma por zOBEL e TALBERT (1984).

O homem produz nudanças drästicas no ambiente dos povoamentos florestais quando utiliza präticas intensivas de manejo florestal. O ambiente pode ser mudado duranto o cultivo das essências florestais com adubações, irrigações, podas, desbastes ou quando são adaptados espaçamentos diferentes, além de outros tratos culturais que influem dirata mente no solo e no crescimento das ärvores.

Conforme salienta MORGENSTERN (1982), muitos outros fatores ainda não conhecidos influenciam no desenvo vimento dos povoamentos florestais e afetando na interação,os quais devem ser considerados nos programas de melhoramento. 
Dentre eles merecem destaque os tratos culturais e o espaçamento entre plantas.

Segundo MARQUEZ (1985) ainda que em aparência o ambiente não mude por influências externas, os genótipos apresentam a tendência de modificar o ambiento em que vegetam. Assim, conforme as ārvores crescem, o sombreamento in terno da parcela vai-se incrementando e ocorrem mudanças na temperatura, na umidade relativa, na disponibilidade de ägua e de nutrientes, mudanças essas que afetam o desenvolvimento e as características das plantas.

Existem caracteres que não sofrem grandes a terações com as variações ambientais, porëm, os caracteres de maior interesse econômico geralmente são quantitativos e, portanto, pequenas variações no ambiente são suficientes pa ra provocar modificações fenotípicas significativas, como se riam os casos da produção, altura, diâmetro, etc., nas espê cies florestais.

KAGEYAMA (1980) enfatiza que o fenótipo retie te influências ambientais e genêticas e, alêm disso, que os genötipos respondem distintamente às variações ambientais, mostrando que essa resposta diferercial dos efeitos genotípi cos e ambientais no desenvolvimento dos organismos dá origem ao importante grupo de parâmetros conhecidos como interação de genótipo e ambiente.

SHELBOURNE (1972) afirma que o genótipo de um indivíduo só pode ser avaliado a partir de seu fenötipo. Os 
efeitos do genótipo e do ambiente não são independentes e os genótipos diferem em suas réspostas fenotípicas a um ambiente. MATHESON (1978), por sua vez, indica que os fenótipos re sultam da interação genótipo $x$ ambiente.

MORGENSTERN (1982) relaciona os fatores que são as bases de muitas interações: (a) diferenças climáticas, consistentes em mudanças em foto e termoperíodo e expressas pela variação na sobrevivência, no ritmo de crescimento e na suscetibilidade a pragas e doenças, dentro dos conjuntos de ambientes inclusos numa sërie de ensaios; (b) diferenças de solo entre ambientes, quando os genótipos são específicos pa ra um sitio de maneira que não podem tolerar deficiências nu tricionais ou são menos vigorosos que no seu habitat original; (c) diferenças genêticas das populações testadas, quan do alguns dos genótipos ou procedências podem apresentar uma maior adaptação a condiçōes ambientais variadas (genótipos estáveis), embora outros sejam menos adaptados.

Por outro lado, SQUILLACE (1969) cita os tipos de diferenças ambientais relacionadas com a interação ge nótipo x ambiente: (a) dentro de pequenas äreas, como nos en saios no zampo, associadas con as repetições de um experimen to; (b) entre "sites" dentro de regiões, associadas.com tes tes repetidus en diferentes "sites" dentro de uma região re lativamente uniforme em clima; (c) entre ensaios em diferen tes regiões, onde se incluem testes dentro de uma grande ärea geogräfica com muitas diferenças topogräficas e climáticas; 
(d) entre repetições no tempo, incluindo plantações experimentais repetidas em diferentes anos e sem muitas diferenças espaciais; (e) entre ambientes criados axtificialmente, incluindo experimentos com tratos culturais como fertilização, irrigação, etc.

Segundo SHELBOURNE (1972), os fatores edáficos parecem estar mais fortemente correlacionados com as intera ções genótipo $x$ ambiente.

Segundo CAMPBELL (1974), a interação genótipo $x$ ambiente apresenta grande importāncia dentro da silvicultu ra, principalmente naquelas localidades onde as florestas são regeneradas ou implantadas. Na regeneração das florestas na tivas, a interação apresenta uma estreita relação com a deli mitação das zonas produtoras de sementes, visando limitar ou ainda dirigir a transferência das sementes dentro das zonas. geográficas predeterminadas, das florestas onde são colhidas aos ambientes onde serão estabelecidas as novas florestas.

No caso das florestas implantadas com espécies exóticas, um dos objetivos a atingir serä escolher as melho res procedências ou famỉlias para os "sites" onde serão esta belecidas as novas florestas (BURLEY e NIKLES, 1973; BURLEY e KEMP, 1973), tentando, assim, diminuir os efeitos da interação e evitar perdas no povoamento por mortalidade das ärvo res ou a diminuição da qualidade.

As präticas de cultivo para incrementar a pro dutividade das árvores, tal como a fertilização, admitem tam 
bém a possibilidade de melhoramento das ärvores para aumentar a sua eficiência na resposta à adubação. Segundo Smith e Goddard (1973), citados por DANIELS (1984), a resposta das árvores à fertilização é controlada geneticamente em um cex to grau, podendo-se, portanto, tirar vantagem das interações genótipo x fertilizante na seleção, para certo tipo de ârvo res que possam maximizar a sua eficiência na utilização dos fertilizantes aplicados. E importante salientar que essas âr vores serão grandemente dependentes, para o seu desenvolvimento, das aplicaçöes dos fertilizantes.

BURDON (1971), trabalhando com clones de PL nus radiata D. Don, estabelecidos em quatro "sites", à idade de 12 anos; encontrou uma grande interação clone $x$ "site" pa ra a frequência de ramificação e para retidão de tronco, a qual foi relacionada à deficiência de fósforo. A tolerância à deficiência de fósforo apresentou-se como sendo específica aos diferentes clones. Teich e Holst (1974), citados por MOK GENSTERN (1982), em estudo para determinax as interações pro cedência x "site" em Picea glauca (ivoench) Voss, encontzaram uma alta significância, que foi relacionada, tanto para as procedências quanto para os "sites" onde foram estabelecidos os testes, como sendo devida às diferenças ao contéüdo de câlcio no solo.

Segundo ZOBEL e TALBERT (j.984), a interaçãc não esteve presente quando foram aplicados fertilizantes em doses normais, embora, quando a interação foi detectada, es 
ta foi altamente dependente das espécies e das familias tes tadas. Segundo Goddard (1975), citado por 2OBEL e TALBERT (1984), o Pinus elliottii Engelm apresentou maior interação genótipo $x$ fertilizante que o Pinus taeda L., sendo a intera ção bem maior com fertilizantes à base de fósforo. Por sua vez, SHELBOURNE (1972) e JAHROMI et alii (1976) relataram in terações definidas de fósforo $x$ famỉlias para Pinus taeda L. e Pinus radiata D.Don.

E bem conhecido que o fenótipo reflete influências ambientais e genéticas e, além disso, que os genóti pos respondem distintamente às variações ambientais. Assim, as espécies arböreas, quando colocadas sob espaçamentos dife rentes, apresentam respostas diferentes. DANIELS (1984) rela ta que clones de Populus spp apresentaram respostas diferen tes quando cresceram sob espaçamentos diferentes. BALLONI e SIMƠES (1980) reportaram um comportamento similar ao níve] da espécies de Eucalyptus.

Os experimentos com espëcies florestais usdr. do o espaçamento como um fator de interação com o genötipo são raros na literatura, muito embora, como já salientado, os efeitos do espaçamento influam no crescimento das espécies florestais e na produtividade des povoamentos, e tendo uma grande importância nos aspectos tecnológicos e econômico da madeira produzida.

Mathieu (1967), citado por MORGENSTERN (1982), estudou os efeitos de dois espaçamentos $(0,3 \times 0,3$ e $1,0 \quad x$ 
$1,0 \mathrm{~m})$, em procedências de Pinus sylvestris $\mathrm{L}$, avaliando as características de sobrevivência, altura, diâmetro, formas do tronco e häbito de ramificação, e encontrando significância somente para a interação relativa à sobrevivência.

CAMPBELL e WILSON (1973), citando Allard e Bradshaw (1964), indicam que as interações genótipo x espaça mento são problemas para o melhorista, devido a que as interações podem camuflar os valores dos genötipos. Nesses casos, o aspecto importante das interações é o tamanho relativo des ses efeitos. Evans et alii (1966), citados por CAMPBELL e WIL SON (1973), propõem que as interações estatisticamente signi ficativas podem ser uma expressão: (a) das mudanças no nível dos genôtipos sobre diferentes espaçamentos, ou (b) das mudanças na variância entre genôtipos a diferentes espaçamen tos, ou (c) de uma combinação de nudanças em níveis e variân cia.

CAMPBELL e WILSON (1973) trabaiharam com 30 familias de irmãos germanos de Pseudotsuga menziesie (Miir)) Franco, utilizando um delineamento de parcelas subdivididas onde os espaçamentos foram inclusos nas parcelas e as famílias colocadas nas subparcelas. Os autores encontraram inte rações progênies x espaçamento para as características altu ra e índice de volume, mas não para o caso da altura, quando foram utilizados os dados sem transformações. Quando as an $\underline{\hat{a}}$ lises de variancia foram feitas com os dados transformados as interações não foram mais significativas. 
FRIES (1984) estudou a interação genôtipo $x$ espaçamento em Pinus sylvestris L., utilizando mudas produzi das a partir de sementes (população geneticamente heterogênea) e de clones enxertados (população geneticamente homogệ nea), visando detectar a ocorrência de interações competiti vas entre elas. O autor encontrơu interações entre o espaçamento e o grau de variação genética, mas para o caso da inte ração genótipo $x$ espaçamento não foi detectado nenhum grau de significância.

BURDON (1977) alerta que no melhoramento das ärvores florestais hă necessidade de se prestar maior atenção às condições ambientais que aos genótipos na geração de interações e afirma que o desenvolvimento de um genötipo com relação a um outro genótipo pode variar em função do meio am biente podendo acontecer que un genj́tipo superior em uma le calidade ou ambiente não o seja em outros locais ou ambientes.

Muitos autores salientam a importância da $\dot{i}_{\underline{n}}$ teração gerótipo x ambiente no melhoramento florestal, indi cando que ela afeta a estratégia dos programas e da seleção (NAMKOONG et alii, 1966; SHELBOURNE, 1972; KAGEYAMA, 1980; KANG, 1980; NAMKOONG et alii, 1980 e TALBERT, 1980). NAMKOONG et alii (1980) mostraram que, em função dos objetivos do me lhoramento, a seleção pode favorecer genótipos amplamente adaptados ou que responden particularmente bem em ambientes especificos. 
Segundo MATHESON e RAYMOND (1984), a interação genótipo $x$ ambiente é causada pelo desvio dos valores ge notípicos individuais em un "site", a partir dos efeitos adi. tivos dos genótipos e os ambientes. Os desvios podem surgir devido às mudanças no comportamento cios genótipos entre "sites" ou devido à variação na expressão do comportamento dos ge nes que controlam essa característica.

Para a detecção das interações genôtipo $x$ am biente tem sido desenvolvida una grande variedade de tëcnicas estatísticas. Os. objetivos a serem atingidos voltam-se à descoberta de quais ambientes e quais genótipos causam a maior parte da variância da interação e à caracterização dos genótipos quanto a sua estabilidade.

o primeiro passo para o estudo das interaçốes é uma análise da variância das observações dos materiais ge nêticos comuns aos diferentes "sites". Gibson (1982), citado por MATHESON e RAYMOND (1984), apresenta um exemplo onde a interação entre procedências e "sites" ê testada através da comparação ło quadrado médio da interação com o quadrado médio do erro experimental.

VENCOVSKY (1.978) discute a importância de se conhecer até que ponto os fatores ambientais mascaram o valor genotîpico dos indivíduos. Assim, o autor citado mostra que quando o carâter a ser melhorado é muito influenciado pt 10 ambiente, deve-se utilizar um delineamento experimental a dequado, um número suficiente de repetições e uniformizar ao 
māximo o ambiente.

As interaçõés entre materiais genéticos e diferentes ambientes têm sido comuns em muitas espécies flores tais, muito embora a quantificação desses efeitos para muitas características tenha alguma restrição. A significância estatística da interação, detectada pela anālise de variância, só indica que a mesma foi estimada de uma forma precisa e não que ela seja necessariamente importante.

SHELB URNE (1972) e ZOBEL e TALBERT (1984) sa lientam que o ünico caminho para avaliar à presença da interação genótipo $x$ ambiente é instalax testes e provar os mate riais genéticos em mais de un ambiente. Tambêm zOBEL e TALBERT comentam que, quando os testes säo estabelecidos numa só localidade a interação pode ficar disfarçada dentro do efeito genético. Por sua vez, SHelfourne cita värios métodos para a avaliação da interação genôtipo $x$ ambiente e para a seleção de populações visando a sua estabilidade; esses méto dos são:

(a) classificação das mëdias de f́amilias, procedências ou clones nos diferentes ambientes;

(b) correlação entre mêdias de procedências, famỉlias ou clones, em pares de ambientes;

(c) análises de variância; e

(d) regressão das médias de famijlias, procedências ou clo nes com os ambientes envolvendo todas as médias de to dos os locais. 
Por sua vez, BARNES et alii (1984) indicaram os seguintes mëtodos para se detectar e avaliar os efeitos da interação genótipo $x$ ambiente:

(a) anālise da variância normal;

(b) anālises da variância modificadas com a omissão de ca da um dos ambientes e genótipos, visando determinar as contribuições individuais aos componentes da variância da interação e a consistência dos genótipos em tó dos os ambientes;

(c) anâlises dos graus de liberdade individuais ou de con sistência para examinar o efeito do nivel de contribuição de cada um dos fatores;

(d) isolamento dos componentes da variância da interação genötipo $x$ ambiente;

(e) utilização da têcnica de regressão conjunta, onde o comportamento genotipico è comparado contra a média de toros os genōtipos separadamente em cada um dos ambi enies, ou contra algum estimador externo da qualidade do "site". A variância da interação é decomposta em dois termos: a regressão da heterogeneidade entre os genótipos e o desvio da regressão de cada um dos genô tipos; e

(f) a correlação genétjca entre o comportamento de cada um dos genótipos em cada par de ambientes.

Segunđo ZOBEL e TALBERT (1984), quando existe a presença de uma grande interação genôtipo $x$ ambiente, isso 
pode provocar que a herdabilidade seja superestimada e, segundo os autores citados, á fórmula apropriada para obter a herdabilidade no sentido restrito, quando os testes são esta belecidos em várias localidades, seria:

$$
h^{2}=\frac{\sigma^{2} A}{\sigma^{2} A+\sigma^{2} N A+\sigma^{2} G E+\sigma^{2} E} \text {, onde: }
$$

$\sigma^{2} \mathrm{~A}=$ variância genêtica aditiva; $\sigma^{2} \mathrm{NA}=$ variância genêtica não aditiva; $\sigma^{2} E=$ variância ambiental e $\sigma^{2} G E=$ variância da interação genótipo $x$ ambiente.

Os autores ainda citam que na presença de in teração genótipo $x$ ambiente e com informação de um sô ambien te, o cálculo da herdabilidade ficaria:

$$
h^{2}=\frac{\left(\sigma^{2} A+\sigma^{2} G E\right)}{\sigma^{2} A+\sigma^{2} N A+\sigma^{2} G E+\sigma^{2} E}
$$

Finalmente, os autures comentam que quando os testes são estabelecidos num sô local, os componentes da variância genêtica aditiva e da interação genôtipo $x$ ambiente são confundidos e não podem ser separados, o que pode condu zir a uma superestimação dos ganhos na seleção, sobretudo quando o material vai ser estabelecido num local não testado. VENCOVSKY (1978), poi sua vez, destaca a gran de importância do fenômeno da interação de tratamentos com ambientes para o melhoramento e salienta, citando Allard (1971), que a magnitude da interação depende muito do mate- 
rial ensaiado e também das condiçōes ambientais onde o mesmo é colocado. Segundo o autor, do ponto de vista do melhoramen to, o fato da interação genótipo $x$ ambiente ser significativa não esclarece a situação, sendo preciso levar o estudo mais adiante. De fato, continua o autor, pode-se mostrar no caso, que:

$$
\sigma_{t a}^{2}=1 / 2\left(\sigma_{t 1}-\sigma_{t 2}\right)^{2}+\sigma_{t 1} \sigma_{t 2}\left(1-r_{12}\right)
$$

onde: $\sigma^{2}$ ta é a variância da interação de tratamentos $x$ ambi= entes

$\sigma_{t_{1}}$ e $\sigma_{t_{2}}$ são os desvios padrões dos tratamentos nos ambien tes 1 e 2 respectivamente.

$\mathrm{r}_{12}$ é a correlação entre os tratamentos nos ambientes $1 \mathrm{e}$ 2 .

Este desdobramento áa interação, ou de sua com ponente $\sigma^{2}\{a$, representa um fato mais geral, ou seja de que a interação é composta de duas partes, a saber:

(a) uma, devida à diferença na variabilidade genética do material, dentro dos amrientes, no caso $\sigma_{t 1} \sigma_{t 2}$.

(b) a segunda, advinda da falta de correlação entre o material de um ambiente para outro, no caso represen tado por $\left(1-r_{12}\right)$. O importante é se notar que a segunda par te é a mais importante da interação, pois, uma correlação baixa pode significar que o material superior num ambierte pode não o ser no outro. VENCOVSKY (1978) ainda salienta a importância de se perceber que a interação pode existir mesmo com alta correlação entre ambientes.

Segundo ZOBEL e TALBERT (1984), têm sido empregados dois métodos para reduzir a interação genótipo $x$ am biente nos programas de melhoramento. A primeira alternativa 
consiste em se estratificar a população, subdividindo-a em ā reas dentro da região de meíhoramento, ou em sub-regiões, que apresentem condições ambientais semelhantes. As semelhanças podem ser determinadas atravês dos fatores macroambientais como os regimes de temperaturas, regiões fisiogräficas, solos, ou ainda podem ser indicadas pelá experiência e o comportamento dos genötipos em cada uma delas. A segunda alternativa indicada pelos autores tem por objetivo selecionar aqueles genötipos que crescem bem e mostram pouca interação sobre uma ampIa variedade de condições ambientais.

A interação genótipo $x$ ambiente pode produzir perdas que, segundo ZOBEL e TALBERT (1984), podem consistir em: (a) na morte das ärvores e na redução do crescimento, ou (b) efeitos na qualidade da madeira. A primeira ê facilmente reconhecida, embora para se reconhecer a segunda sejam neces sārias observações mais cuidadosas.

E importante salientar que os genótipos podem apresentar interaçōes tanto para os parâmetros do crescimento quanto para as características que definem a qualidade da madeira. As propriedades da madeira que influem na sua quali dade podє̇n, às vezes, apresentar maiores interações do que as características do crescimento (ZOBEL e TALBERT, 1984).

Ainda que existam muitas causas para a intera ção, na maioria dos casos, quando a mesma aparece, tem rela ção maior com os efeitos dos fatores edäficos que com fatores climảticos (SHELBOURNE, 1972; GODDARD, 1977). 


\subsection{Ensaios de Progênies e Determinação de Parâmetros Ge- NEETIICOS}

\subsubsection{ENSAIOS DE PROGÊNIES}

DITLEVSEN (1980) salienta que muitas caracte risticas de interesse no melhoramento florestal são quantita tivas, herdadas pela ação de muitos genes de efeito aditivo, cada um contribuindo para a herança dos caracteres. Geralmen te nos programas de melhoramento são escolhidas árvores feno tipicamente desejáveis para o caráter enfocado. Essa aparên cia fenotípica pode ser consequência de um bom genôtipo, de um bom ambiente ou, ainda pode ser o resultado da interação existente entre o genótipo e o ambiente.

Segundo ZOBEL e TALBERT (1984), a interação ge

nótipo $x$ ambiente pode ser expressa simbolicamente, utilizan do uma extensão do modelo de comportamento fenotípico, rela cionando os efeitos genéticos e ambientais, como a seguir:

$$
F=G+E+G E, \text { onde: }
$$

F è o valor fenotîpico; G é o efeito genētico; E é o efeito do ambiente e GE é o efeito devido à interação genötipo x am biente.

40

Para se estimar a ação da interação mencionada sobre o fenótipo, é necessária a realização de um teste genético, sendo um deles o de progênies. Um teste de progê- 
nies é, em forma objetiva, um plantio dos descendentes, de tal forma a possibilitar a éstimativa do valor genotípico dos pais. E importante considerar na realização de um teste de progênies, a definição da população de genótipos a se testar e dos ambientes onde essas árvores vegetam.

Segundo JOHNSSON (1974), os testes clássicos de progênies são realizados para fazer uma avaliação mais precisa dos pais, do que seria possível fazer só a partirdos fenōtipos.

Considerando-se a longevidade das árvores flo restais, os testes de progênies constituem-se em fontes para novas seleções, alẻm de proporcionar informações dos pais, sendo também utilizados para a conservação dos recursos gené ticos, para demonstrações, estimação dos ganhos genéticos e, ainda, pará a produção de sementes.

Muitos autores têm salientado que o maior pro blema nos testes de progênies consiste em se definir o nümero de familias a serem testadas, c nümero de indivíduos a se considerar dentro de cada parcela, o número ótimo de repetições necessärio e, ainda, a melhor forma de parcela para per mitir ums avaliação adequada de cada uma das famílias dentro do teste.

$$
\text { JOHNSSON (1974) relatou que parcelas de } 6 \times 6
$$
plantas foram suficientes para se obter volumes satisfatórios em função à superfície, para o primeiro terço da rota ção das espécies florestais. O mesmo autor comenta que os 
testes de progênies podem precisar de pelo menos um desbaste durante o período experimental, apontando, ainda, que se o desbaste é feito cuidadosamente, os efeitos do desbaste sobre as características de crescimento são mínimos.

MATHESON e RAYMOND (1984a) estudaram os efeitos do desbaste sobre os parâmetros genéticos em ensaios de progênies de Pinus radiata D.Don, verificaram que em função do método de desbaste utilizado podem ser afetadas as estima tivas da herdabilidade, jâ que são afetadas as estimativas das variâncias genética aditiva e fenotípica. Embora, salien taram os autores, os desbastes em fileiras e a remoção casua lizada das árvores dentro das parcelas, não afetaram as estima tivas das variâncias, mas sim, incrementaram o erro padrão das estimativas da herdabilidade. Por outro lado, o desbaste seletivo incrementou a estimativa da variância genética aditiva e diminuiu a estimativa da variância fenotípica. Ainda MATHESON e RAYMOND verificaram a não existência de grandes diferenças nas estimativas da herrabilidade obtidas imediata mente depois do desbaste, quando comparadas com as obtidas aos 3 e 5 anos depois do desbaste. As variâncias genêtica e fenotípica se incrementaram na mesma proporção, nesse perío do.

MATHESON e RAYMOND (1984a) encontraram que as correlaçōes genéticas entre o diâmetro antes e aos 3 e 5 anos depois do desbaste, foram muito altas, podendo ser inter pretadas como indicativos de que os mesmos genes controlaram 
o crescimento em diâmetro antes e depois do desbaste. As es timativas da herdabilidade para o diâmetro, encontradas pelos autores, foram maiores depois do desbaste, do que antes dele.

WRIGHT (1976) comenta que a herdabilidade e os ganhos genêticos podem ser estimados utilizando-se a rela ção entre os pais e as descendências, obtida pela avaliação do crescimento das ârvores e de suas descendências. Outra ma neira de se estimar esses parâmetros consiste em estabelecer um ensaio de progênies de irmãos germanos ou de meios irmãos e obter a hərdabilidade em função das variâncias.

Segundo ZOBEL e TALBERT (1984) a melhor forma de avaliar o valor das ärvores selecionadas é através do de senvolvimento das suas progênies, de forma a permitir estimar os valores dos progenitores. Esse procedimento permite separar as ärvores cujas superioridades fenotípicas sejam produzidas pelas boas condições do "site" onde vegetam, daquelas qué apresentam uma superioridade genotípica.

Segundo KAGEYAMA (1980) e ZOBEL e TALBERT (1984), os testes de progênies instalados tanto a partir de sementes de polinizaçäo livre como de cruzamentos controlá. dos têm sido importantes na determinação do valor reproduti vo das árvores selecionadas, permitindo a estimativa dos pa râmetros genéticos, possibilitando, assim, a seleção de novos individuos superiores.

KAGEYAMA (1980), citando Shelbourne (1969) e 
Keiding (1974) relaciona os principais objetivos dos testes de progênies para espécies f́lorestais, como sendo:

(a) estimar a capacidade geral de combinação de clones com o objetivo de ordenā-1os e resselecionar os melhores;

(b) estimar a capacidade específica de combinação e iden tificar cruzamentos particulares entre dois pais que mostrem alta especificidade nos cruzamentos;

(c) estimar os parâmetros genêticos, tais como variâncias aditivas e dominantes, coeficientes de herdabilidade, correlações genéticas, etc.;

(d) prover uma fonte de material genêtico para futuras se leções; e

(e) predizer os ganhos a serem obtidos.

Ainda KAGEYAMA salienta que para espécies flo restais o mêtodo de ensaio de progênies mais utilizado é o de progênies de polinização aberta, visando a resseleção das árvores para programas de melhoramento genético e a estimati va dos parâmetros genêticos.

Shelbourne e Cockrem (1969), citados"por KAGEYAMA (1980), mostram que o teste de progênies de poliniza ção aberta é o mêtodo mais barato e atrativo, apesar das des vantagens e restrições que o mesmo apresenta em relação aos testes de polinização controlada. 
Rink e Thor (1976), citados por KAGEYAMA (1980), enfatizam que a maioria das estimativas dos componentes de variância em espêcies florestais é baseada em experimentos em um só ambiente, o que pode inflar essas estimativas pela pre sença de uma interação de genótipos por ambiente.

\subsubsection{Determinação de parâmetros genÉticos}

DITLEVSEN (1980) relata que uma grande quanti dade das características de interesse para o silvicultor é quantitativa, controlada pela ação de muitos genes de efeito aditivo. As caracteristicas fenotípicas, em geral, apresentam variações entre indivíduos que são em parte devidas às diferenças hereditârias e ambientais entre eles, sendo que cada característica desenvolvida ê o resultado da ação dos genes, do ambiente e da interação entre eles.

Segundo ROBINSON e COCKERHAM (1965), a estima ção dos parâmetros genéticos possibilita a obtenção de infor mações para o conhecimento da natureza da ação gênica envolvida na herança dos caracteres e fornece as bases para a de finição dos programas de melhoramento da população, o direcionamento dos esquemas mais adequados de seleção e a avalia ção dos progressos esperados através dos mesmos.

Segundo ELDRIDGE (1971), a existência de variação estatisticamente significativa entre famílias para 
qualquer caráter é entendida como sendo a possibilidade des se caráter ser melhorado péla seleção. Entretanto, DUDLEY e MOLL (1969) argumentam que tal constatação não quantifica a variabilidade genética dentro dessa população. A estimativa da herdabilidade no sentido restrito proporciona esse conhecimento, informando sobre a magnitude relativa da variação genética e da ambiental.

Um dos propósitos ao se estimar os parâmetros genéticos, segundo ELDRIDGE (1978), é o de predizer os ganhos com estratégias alternativas para o melhoramento genéti co, permitindo a escolha da melhor estratégia de melhoramento para essa população.

BOGYO (1964), ROBINSON e COCKERHAM (1965) e Vencovsky (1969), este citado por KAGEYAMA (1980), relatam que os propósitos ao estimar os parâme乞́ros genéticos seriam:

(a) proporcionar informações sob a ação dos genes respon sảveis pela herança das características estudadas;

(b) proporcionar as bases para a avaliação dos programas de melhoramento da população e a informação para o de senvolvimento de novos enfoques nos programas; e

(c) estimar o progresso esperado na seleção.

Esses autores colocam ainda, que as variâncias dos genótipos e sua interação com o ambiente devem ser inter pretadas em função da população que deu origem às matrizes. 
Muitos autores têm salientado que o melhoramento efetivo obtido através da seleção dentro de uma popula ção, depende da presença de suficiente variância genética aditiva, já que, dos componentes da variância total, somente os de natureza genética são aproveitáveis na seleção. Portan to, todo o sucesso do programa vai depender da quantidade de variância genética disponível, em relação à variância não ge nética.

Segundo VENCOVSKY (1978) e FALCONER (1983) na propagação das plantas alógamas por via sexuada, o componente de variância mais importante para o melhoramento é a con tribuição devida aos efeitos aditivos dos genes. Segundo os autores citados, a variância genética pode ser composta em variância genética aditiva e não aditiva, a última citada compreendendo a variância dominante e a epistática.

ROBINSON e COCKERHAM (1955) salientam o fato de que os parâmetros genéticos estimados devem ser independentes dos efeitos ambientais, condição que se satisfaz se não houver interação com o ambiente, recomendando o teste dos genôtipos em uma série de ambientes, de maneira a se separar a variância devida à interação genótipo x ambiente da variân cia genética.

KAGEYAMA (1980) relata que o ganho genético é também influenciado pelo coeficiente de variação da população, uma vez que o maior ganho para uma mesma intensidade de seleção não é conseguido para a característica mais altamen- 
te herdável, mas sim, para aquela com o maior valor para o produto entre o coeficiente de variação e a herdabilidade.

KAGEYAMA (1980), citando Vencovsky (1969), sa lienta que para uma estimação ampla e sem restrições dos com ponentes da variância genética, precisa-se que os indivíduos que constituem o material experimental sejam não endocruzados. Por sua vez, Namkoong (1966), citado por KAGEYAMA (1980), levanta que se a endogamia ocorre na população, o teste de progênies de polinização aberta apresenta restrições, afetan do nas estimativas das variâncias genéticas.

Existem muitos processos para estimar os com ponentes de variação, embora a têcnica mais utilizada para de compor a variação total de cada componente seja através das análises da variância dos experimentos em blocos ao acaso e em lätice. FONSECA (1979) relata que esta têcnica tem uma du pla finalidade, quando utilizada nos ensaios de melhoramento: (a) testar diferenças entre tratamentos; e (b) estimar os com ponentes da variância.

Os estudos de parâmetros genéticos das popula ções para as diferentes caracterîsticas das ärvores, conforme salienta KAGEYAMA (1980), têm-se concentrado principalmen te na determinação das variâncias e covariâncias genêticas, principalmente quanto às suas partes aditivas, visando às es timativas de herdabilidade no sentido amplo e restrito, assim.como de correlações genéticas.

Um dos objetivos mais comuns na estimação das 
variâncias genéticas é a estimação da herdabilidade, parâme tro que, segundo BOGYO (1964), é definido como a relação en tre a variância genêtica aditiva e a variāncia total, que po de ser atribuída a um efeito médio dos genes. SQUILlACE et alii (1967) e FALCONER (1983) mostram que o conhecimento da herdabilidade é fundamental nos programas de melhoramento, jâ que permite a predição dos ganhos genéticos, auxiliando na escolha e estabelecimento de métodos apropriados de melhoramento para a espécie estudada.

Segundo FALCONER (1983), o termo herdabilida de é a descrição quantitativa da relação entre a variação he reditâria e a variação fenotípica em uma característica, ou a expressão da confiança do valor fenotípico como guia para o valor genêtico. Segundo DUDLEY e MOLL (1969), ela pode ser expressa no sentido amplo e restritc. No sentido amplo, é a relação da variância genética total para a variância fenotípica, enquanto que no sentido restrito é a relação da variân cia genética aditiva para a variância fenotípica. o valor da herdabilidałe varia de 0 a 1 . Quando a herdabilidade è alta, diz-se que o controle genêtico é alto, ou seja, que a característica é altamente herdável. Quando a herdabilidade é bai xa, diz-se que a característica é ligeiramente herdāvel ou grandemente dependente do meio.

A herdabilidade depende de todos os componentes de variância, e a alteração em qualquer um deles afetará tambēm o seu valor. Sendo assim, quando for mencionado o va 
lor para a herdabilidade de um caráter, o mesmo estará se re ferindo a uma população em particular, sob condições específicas (FALCONER, 1983). Desta maneira, a quantidade de varia ção ambiental não controlada pode limitar um possível ganho genético na seleção de uma população.

KAGEYAMA (1980) salienta que as característi. cas das árvores, consideradas importantes no melhoramento flo restal, poderiam ser agrupadas em: (a) características de crescimento; (b) características de forma das ärvores; características da qualidade da madeira; e (d) outras. As ca racteristicas associadas ao crescimento, tais como a altura total, o diâmetro (DAP) e o volume de madeira, são considera das como as mais importantes, em função de seu valor econômi co.

Quanto à estimação das variâncias genëticas e. do coeficiente de herdabilidade para essas características, os resultados obtidos apresentam uma grande variabilidade om função das espécies e dos métodos empregados.

ELDRIDGE (1972) encontrou uma herdabilidade de 0,2 para diâmetro em Eucalyptus regnans F.Muell, aos 7 anos de idade, e de 0,37 e 0,21 para altura, aos 6 e 4 anos de idade, respectivamente. Por sua vez, KEDHARNAT e V̧AKSHASYA (1977), para Eucalyptus tereticornis, encontraram baixos va lores da herdabilidade: 0,26 e 0,25 para altura aos 3 e 4 anos, respectivamente, sendo que para o diâmetro o valor re portado foi de 0,17 . 
KAGEYAMA et alii (1978), num ensaio de progê nies de Pinus patula Schl ét cham, encontraram valores de herdabilidade diferentes entre locais, para altura, diâmetro e retidão do tronco, sendo que as estimativas observadas pa ra diâmetro foram sempre inferiores àquelas encontradas para as outras características.

KAGEYAMA (1980) fez uma revisão dos valores de herdabilidades reportadas na literatura, para as diferen tes características de crescimento em ärvores florestais, re latando que as estimativas de herdabilidade obtidas apresen tam uma tendência, em média, para maior herdabilidade para altura do que para diâmetro e volume, confirmando a conclusão da maioria dos autores. O mesmo autor relata que os dados obtidos nos ensaios de Eucalyptus grandis Hill Ex Maiden mos traram que as correlações genotípices e fenotípicas entre a tura, DAP e volume cilíndrico para essa espëcie são altas, positivas e significativas. Esse fato auxilia o seu melhoramento através da seleção.

BORGES (1980) encontrou valores semelhantes de herdabilidade para altura e diâmetro de Eucalyptus grandis Hill Ex Maiden, reportando o coeficiente de herdabilidade pa ra altura, aos 6 meses de idade, de 0,37 .

Muitos autores têm estudado, para os Eucalyptus, o comportamento do coeficiente de herdabilidade em fun ção das características de crescimento, forma das ärvores e ainda para características ligadas à qualidade da madeira. Na 
tabela 4 , a seguir, podem ser observados alguns dos resultados obtidos por diversos pésquisadores, para as característi cas de crescimento em espécies de Eucalyptus.

Tabela 4 - Coeficientes de herdabilidade $\left(h^{2}\right)$ no sentido restrito, para altura, diânetro e volume, em espécies de Eucalyptus.

\begin{tabular}{|c|c|c|c|c|c|}
\hline \multirow{2}{*}{ ESPECIE } & \multirow{2}{*}{ IDADE } & \multicolumn{3}{|c|}{$h^{2}$} & \multirow{2}{*}{ FONTE } \\
\hline & & $\mathrm{A}$ & $\mathrm{D}$ & $\mathrm{V}$ & \\
\hline $\begin{array}{l}\text { Eucalyptus grandis } \\
\text { Hill ex Maiden }\end{array}$ & $6 \mathrm{~m}$ & 0,37 & - & $\longrightarrow$ & BORGES (1980) \\
\hline $\begin{array}{l}\text { Eucalyptus giundis } \\
\text { Hill ex Maiden }\end{array}$ & $2 a$ & 0,26 & 0,15 & 0,14 & KAGEYAMA (1980) \\
\hline $\begin{array}{l}\text { Eucalyptus grandis } \\
\text { Hill ex Maiden }\end{array}$ & $5 a$ & 0,23 & 0,11 & 0,16 & KAGEYAMA (1983) \\
\hline $\begin{array}{l}\text { Eucalyptus grandis } \\
\text { Hill ex Maiden }\end{array}$ & $7 a$ & 0,28 & 0,13 & 0,10 & MORAES (1986) \\
\hline $\begin{array}{l}\text { Eucalyptus grandis } \\
\text { Hill ex Maiden }\end{array}$ & $2 a$ & . & - & 0,23 & VAN WYK (1976) \\
\hline $\begin{array}{l}\text { Eucalyptus grandis } \\
\text { Hill ex Maiden }\end{array}$ & $3 a$ & - & - & 0,33 & VAN WYK (1978) \\
\hline $\begin{array}{l}\text { Eucalyptus grandis } \\
\text { Hill ex Maiden }\end{array}$ & $3 a$ & - & - & 0,16 & VAN WYK (1978) \\
\hline E. tereticornis & $4 a$ & 0,25 & 0,17 & - & $\begin{array}{l}\text { KEDHARNAT e VAKA- } \\
\text { SHASYA (1.977) }\end{array}$ \\
\hline E. regnans $\dot{F}$. Muell & $4 a$ & 0,21 & - & - & ELDRIDGE (1972) \\
\hline E. regnans F. Muell & $7 \mathrm{a}$ & - & 0,21 & $\ldots$ & ELDRIDGE (1972) \\
\hline E. regnans $F$. Mue 11 & 102 & $\longrightarrow$ & 0,15 & $\longrightarrow$ & ELDRIDGE (1972) \\
\hline E. paniculata SM & $3 a$ & 0,15 & 0,20 & 0,18 & $\begin{array}{l}\text { ASSIS } \\
\text { (1982) }\end{array}$ \\
\hline E. Cloesiana i. Muell & $3 a$ & 0,48 & $0,23^{+}$ & 0,16 & $\begin{array}{l}\text { ASSIS e.t } \\
(1982 d)\end{array}$ \\
\hline E. urophylla S T Blake & $36 \mathrm{~m}$ & 0,36 & 0,24 & $\longrightarrow$ & PINTO JR (1984) \\
\hline
\end{tabular}

$\mathrm{a}=$ anos de idade; $\mathrm{m}=$ meses de idade; $\mathrm{A}=$ altura; $\mathrm{D}=$ diâmetro; $\mathrm{V}=$ volume $\mathrm{e}$ + baseada na CAP (circunferência à altura do peito de progênies de pomar de sementes). 
VENCOVSKY (1978) ressalta a importância do es tudo da correlação entre características dentro dos programas de melhoramento, onde a preocupação principal seria a de aprimorar o material genético, não para características isoladas, mas para um conjunto de carâteres simultaneamente. 0 autor comenta ainda que o grau de correlação, tanto genotípi ca como fenotípica, è de grande importância na seleção de um caráter, pois pode causar mudança simultânea em outro carâter.

FALCONER (1983) mostra que os problemas prâti cos podem-se resolver em função de duas correlações: a corre lação genética (ou correlação dos valores reprodutivos) e a correlação ambiental, a qual contêm os desvios ambientais e os desvios genéticos não aditivos.

A associação entre dois caräteres, que pode ser observâda diretamente, chama-se correlação fenotípica, a qual é determinada através de medições dos caráteres feitas em vários indivíduos da população.

A correlação entre características numa mesma idade, ou entre idades para uma característica, pode ser determinada, segundo KAGEYAMA (1983), pelas equações:

$r_{F(x, y)}=\frac{\operatorname{Cov}_{f(x, y)}}{\sigma_{f(x)} x \sigma_{f(y)}}$ e $r_{G(x, y)}=\frac{\operatorname{Cov}_{g(x, y)}}{\sigma_{g(x)} x \sigma_{g(y)}}$, sendo:

$r_{F}$ e $r_{G}$ os coeficientes de correlação fenotípica ao nível de 
médias de progênies, e genética aditiva ao nível de plantas, respectivamente;

$\operatorname{Cov}_{f(x, y)}$ e $\operatorname{Cov}_{g(x, y)}$ a covariância fenotípica e genética aditiva entre as características e entre as idades considera das, respectivamente;

$\sigma_{f(x)}$ e $\sigma_{f(y)}$ e $\sigma_{g(x)}$ e $\sigma_{g(y)}$ os desvios fenotípico e genéti co aditivo, para as características e para as idades conside radas, respectivamente.

KAGEYAMA (1983) relata que, quanto aos resultados obtidos de correlações genéticas e fenotípicas entre diferen tes idades, os mesmos são bastante desencontrados em termos de metodologias e de tendências para os resultados. 0 autor encontrou para Eucalyptus grandis (Hill) Maiden que as corre lações genëticas e fenotípicas não diferiram substancialmente entre si e, ainda, foram bastante concordantes para os diferentes locais estudados. Assim, para altura de plantas os re sultados mostraram uma clara tendência para uma diminuição do coeficiente de correlação com o aumento da idade. Para os casos do diâmetro e do volume cilíndrico, KAGEYAMA (1983) ressaltá - fato de que os valores obtidos foram bastante similares aos obtidos para altura das plantas. No caso do volume cilíndrico, o autor salienta que as correlações foram sempre altas $(0,73$ a 1,00), o que não ocorreu para o diâmetro, supondo que esse $\underline{\text { fa }}$ to esteja associado ao tipo de característica composta que é o volume cilíndrico e, portanto, sujeito às correlações indí viduais das características primärias. 
.51 .

\title{
3. MATERIAL E METODOS
}

\author{
3.1. Material
}

3.1.1. DESCRIÇÃOO DA POPULAÇÃO

As progênies testadas, produto de polinização livre, foram obtidas de ärvores tomadas ao acaso nas Areas de Coleta de Sementes de Eucalyptus saligna Smith, no Horto de Itatinga, localizado no município de Itatinga, do Estado de São Paulo.

Não existem registros exatos referentes à introdução de tal material e, portanto, da procedência das se mentes. Entretanto, considerando a data de plantio e a análi se botânica do material, acredita-se que sua origem seja aus traliana (DEPTO. DE SILVICULTURA, ESALQ/USP, 1979). A planta 
ção foi estabelecida provavelmente em 1938, em um espaçamen to original de $2,0 \times 2,0 \mathrm{~m}$.

0 Horto de Itatinga vem sendo explorado hä 10 anos pelo Departamento de Silvicultura e pelo Instituto de Pesquisas e Estudos Florestais da ESALQ/USP, com a finalidade de se obter sementes de boa qualidade para atender a deman da do mercado.

Dentro do Horto de Itatinga, foram seleciona dos 12 talhões, identificados como "Ârea de Coleta de Semen tes", com uma superfície total de 181,35 hectares.

As árvores dentro dos talhões apresentam diâa metro médio (DAP) de $47,23 \mathrm{~cm}$, altura mêdia de $44,45 \mathrm{~m}$. No geral, apresentam uma alta homogeneidade quanto à altura (CV) $9,9 \%)$ e diâmetro ( $\mathrm{CV}=4,6 \%$ ) e pode-se perceber, pelas carac terísticas das ärvores, tratar-se de material de superior qua lidade.

As ärvores remanescentes nas äreas de colheita de sementes foram avaliadas subjetivamente quanto à forma dos fustes, obtendo-se uma nota média de 3,42 (escala 1 a 5), que confere às árvores dentro dos talhões uma boa forma, assim como uma boa uniformidade entre talhões, evidenciada pe 1o baixo coeficiente de variação obtido ( $C V=12,10 \%)$.

Segundo o DEPARTAMENTO DE SILVICULTURA DA ESALQ/USP (1979), sementes de Eucalyptus saligna Smith, da procedência Itatinga, SP, vêm sendo utilizadas com sucesso, desde 1972, em plantações comerciais em diversas regiões do 
Brasil, principalmente nos Estados de São Paulo, Minas Gerais, Paranä, Mato Grosso do Sul e Rio Grande do Sul.

\subsubsection{LOCALIZAÇÃO E CARACTERİSTICAS DA ÁREA DA POPU LAÇÃ̃o}

0 Horto de Itatinga localiza-se no município de Itatinga, São Paulo, na latitude de $23^{\circ} 10^{\prime} \mathrm{S}$ e $48^{\circ} 40^{\prime}$ de longitude ao oeste de Greenwich, a uma altitude de $857 \mathrm{~m}$.

Segundo Köepen, citado pelo DEPARTAMENTO DE SILVICUL'TURA da ESALQ/USP (1979), o clima da região é um CWa, com temperatura média anual de $21^{\circ} \mathrm{C}$ e uma precipitação média anual de $1296 \mathrm{~mm}$.

Na ärea predominam solos Latossöis e Podzóis, e o relevo é suave e ondulado.

\subsubsection{CARACTERÍSTICAS DO LOCAL DE ESTUdO}

0 experimento foi instalado em feverei ro de 1983, em ārea do parque florestal "Guarujá", ḍa Compa nhia Reflorestadora Nacional (CIRENA), do grupo RIPASA, no município de Avaré, Estado de São Paulo.

As características do local de estudo são as seguintes: 
Latitude: $23^{\circ} 11^{\prime} \mathrm{W}$;

Longitude: $48^{\circ} 47^{\prime} \mathrm{S}$; e

Altitude: $660 \mathrm{~m}$.

o clima è de tipo CWa, segundo a classificação de Koeppen, com temperatura mêdia anual de $23,5^{\circ} \mathrm{C}$ e precipitação anual de $1300 \mathrm{~mm}$.

Dados referentes à precipitação e temperatü ras mẻdias mensais, para o período de fevereiro de 1983 a ja neiro de 1985 , são apresentados no apêndice.

\subsection{MËTODOS}

\subsubsection{INSTALAÇÃ̃ E CONDUÇÃO DO TESTE DE PROGÊNIES}

Para o presente trabalho de dissertação, foi utilizado o teste de progênies de Eucalyptus saligna Smiih, procedência Itatinga, São Paulo, estabelecido no Parque Flo restal "Guarujā", propriedade da Companhia Reflorestadora Na cional (CIRENA) do grupo RIPASA.

As progênies utilizadas no decorrente teste foram provenientes de 169 ârvores matrizes, localizadas nos 181,35 hectares considerados como "Areas de Coleta de Semen. tes", dentro do Horto Florestal de Itatinga.

As mudas foram produzidas no Parque Florestal 
"Guarujâ", no município de Avarê, São Paulo, seguindo a sis temätica normal de trabalhó de produção de mudas.

O preparo do solo foi feito com grade "Bedding", mediante reforma de plantação de eucalipto, fazendo um camalhão sobre o qual foram plantadas as mudas. Na data do plan tio foram aplicadas 100 gramas por planta de fertilizante (NPK) da fórmula 6-30-6, sendo aplicada em sulco e com trator (ara do terraceador).

0 espaçamento inicial do teste foi de $3,0 \quad x$ $1,0 \mathrm{~m}$, entre fileiras e entre plantas da mesma fileira, respectivamente.

Da data de plantação atê julho de 1984, o en saio foi submetido a quatro capinas manuais e uma capina me cânica, com a finalidade de eliminar a competição das ervas daninhas com as plantas das progênies, principalmente durante os primeiros meses após o seu estabelecimento.

\subsubsection{DELINEAMENTO EXPERIMENTAL}

O delineanento utilizado para o estabelecimen to do teste foi um lätice quádruplo $13 \times 13$, segundo COCHRAN e COX (1965), considerando os quatro primeiros planos bâsicos, os quais foram devidamente casualizados. 
As parcelas no teste foram lineares e consti tuídas originalmente por 20 plantas, as quais representam uma progênie.

o teste foi circundado por uma bordadura com as mesmas progênies misturadas, visando a evitar efeitos da borda dentro do teste.

Visando a quantificar a interação genótipo $x$ espaçamento e como ela se reflete nas características silviculturais das progênies e na sua variação genética, foram a plicados desbastes mecânicos na metade de cada parcela (aos 17 meses de idade), para se obter dentro de cada uma delas os dois espaçamentos a testar: $3,0 \times 1,0 \mathrm{~m}$ e $3,0 \times 2,0 \mathrm{~m}$.

O desbaste foi aplicado na mesma metade das parcelas das diferentes repetições, visando a facilitar a operação e a evitar que parcelas com diferente espaçamento fi cassem lado a lado.

Como não foi efetuada a casualização das par celas com espaçamento $3,0 \times 1,0$ e $3,0 \times 2,0$ m dentro da par cela original, devido às dificuldades de operacionalização e mesmo para se evitar o efeito de um espaçamento sobre o outro, optou-se pela anâlise na forma de dois experimentos di ferentes, referentes aos dois espaçamentos, mesmo consideran do essa restrição. 


\subsubsection{AVALIAÇAO DOS ENSAIOS}

Os ensaios de progênies foram avaliados no cam po, nas idades de 15 (antes do desbaste), 26 e 32 meses, uti lizando-se para a avaliação os dados de altura total em metros, diâmetro à altura do peito. (DAP) em centímetros, e a porcentagem de sobrevivência nas parcelas.

A avaliação da altura e DAP foi feita ao nîvel de plantas individuais, de onde foram obtidas as médias de parcelas por planta, enquanto que para sobrevivências os da dos obtidos foram de totais de parcelas por parcela. A ava liação dos parâmetros altura e diâmetro foi feita utilizando-se o esquema tradicional, empregando-se rêguas graduadas e dendrômetro "Blume-Leiss".

Quanto aos dados de volume cilîndrico e ărea basal, os mesmos foram calculados tambêm ao nível de médias de parcela por planta, através da utilização dos dados de a 1 tura e diâmetro (DAP) de cada árvcre individual. o volume ci líndrico e a ārea basal foram obtidos para cada uma das árve res individuais e as médias de parcelas consistiram das soma törias de todas as árvores constituintes da parcela.

A avaliação da densidade básica da madeira foi feita utilizando-se o mëtodo da båança hidrostática, em dis cos de madeira. Os discos de madeira foram obtidos através do método destrutivo, durante o desbaste efetuado aos 17 meses 
de idade, fazendo-se uma amostragem somente na repetição W do teste de progênies origínal, colhendo-se as amostras das ārvores derrubadas, à altura de $1,30 \mathrm{~m}$. As amostras consisti ram de 5 a 6 discos de madeira de cada uma das progênies, sob estudo. As médias obtidas para a densidade básica foram ao nível de médias de parcelas por'planta.

0 método da balança hidrostática é um dos mé todos mais empregados para a determinação da densidade básica da madeira, utilizando-se discos ou cunhas de madeira. 0 procedimento, segundo SILVA (1984), è o seguinte:

(a) saturação da amostra em āgua, com auxílio de dessecą dor (vâcuo);

(b) determinação do peso da amostra em estado imerso, com auxílio de um dispositivo especial acoplado ao prato da balança ou diretamente à amostra imersa;

(c) remover a água superficial e proceder nova pesagenn (peso ümido);

(d) secagem das amostras em estufa a $105 \pm 3^{\circ} \mathrm{C}$, ate peso constante; e

(e) proceder à nova pesagem (peso seco).

A partir dos valores obtidos, tem-se a densi dade bâsica, fornecida pela seguinte expressão: 


$$
\mathrm{Db}=\frac{\text { Peso seco }(\mathrm{g})}{\text { Peso úmido }(\mathrm{g})-\operatorname{Peso} \text { imerso }(\mathrm{g})} \text {, sendo: }
$$

$\mathrm{Db}=$ densidade básica expressa em $\mathrm{g} / \mathrm{cm}^{3}$ de madeira.

\subsubsection{ANÄLISE DA VARIÂNCIA INDIVIDUAL PARA CADA UMA DAS CARACTERISTTICAS EM CADA ESPAÇAMENTO}

Foram realizadas anâlises da variância indivi duais para os dados de altura total, DAP (diâmetro à altura do peito), área basal e volume cilindrico, para cada um dos espaçamentos adotados, segundo o esquema para o delineamento em látice proposto por COCHRAM e COX (1965).

0 modelo estatistico utilizado para essas ana lises foi o assinalado por KAGEYAMA (1980; 1983), e que fica:

$$
\bar{Y}_{i j k m}=\mu+t_{i}+b_{j(k)}+r_{k}+\bar{e}_{i j(k)}+\bar{d}_{m(i j k)} \text {, onde: }
$$

$\bar{Y}_{i j k m} \bar{e}$ a observação no indivîduo m, do tratamento i, no blo co $j$ da repetição $k$;

$\mu$ é a mêdia geral;

$t_{i}$ é o efeito de tratamento;

$b_{j(k)}$ é o efeito de blocos dentro de repetições;

$r_{k}$ é o efeito de repetições;

$\bar{e}_{i j(k)}$ é o efeito do erro intrabloco; 
$\overline{\mathrm{a}}_{\mathrm{m}(\mathrm{ijk})} \overline{\mathrm{e}}$ o efeito dentro de parcelas.

A eficiênciá do Iátice, resultado da relação entre o quadrado médio do erro da anâlise em blocos ao acaso e o erro efetivo da análise em látice, foi o parâmetro utili zado para confirmar a validade da instalação dos experimentos no delineamento em látice.

SNYDER (1966) e MIRANDA FILHO (1978) argumen tam que seria mais justificâvel a utilização do látice somen te quando a sua eficiência fosse superior a $110 \%$. Por outro lado, como salientado por DUDLEY e MOL (1969), os delineamen tos, tais como os látices, que confundem diferenças genéticas e ambientais entre médias de tratamento, não são os mais satisfatórios quando os interesses se voltam mais para as e timativas das variâncias do que para comparação de médias de tratamentos.

Em função do exposto, foram utilizados no pre sente trabalho os esquemas de lätice e blocos ao acaso, tanto para a comparação de médias de tratamentos quanto para es timar os componentes da variância, visando a comparar os ré sultados obtidos em ambos os delineamentos.

Assim sendo e utilizando os tratamentos ajustados (lätice) ou não ajustados (blocos ao acaso), aos níveis de médias de parcelas por planta, as estruturas das anālises da variância individuais ficaram: 


\begin{tabular}{|c|c|c|c|}
\hline FV & GL & QM & $E(Q M)$ \\
\hline Progênies ajustadas & $k^{2}-1$ & $Q_{1}$ & $(1 / \bar{n}) \sigma_{\mathrm{d}}^{2}+\sigma_{\mathrm{e}}^{2}+r \sigma_{\mathrm{p}}^{2}$ \\
\hline Erro efetivo & $(\mathrm{rk}-\mathrm{k}-1)(\mathrm{k}-1)$ & $\mathrm{Q}_{2}$ & $(1 / \bar{n}) \sigma_{\mathrm{d}}^{2}+\sigma_{\mathrm{e}}^{2}$ \\
\hline Progênies não ajustadas & $\mathrm{p}^{-1}$ & $Q_{1}$ & $(1 / \overline{\mathrm{n}}) \sigma_{\mathrm{d}}^{2}+\sigma_{\mathrm{e}}^{2}+r \sigma_{\mathrm{p}}^{2}$ \\
\hline Erro (BAA) & $(r-1)(p-1)$ & $Q_{2}$ & $(1 / \overline{\mathrm{n}}) \sigma_{\mathrm{d}}^{2}+\sigma_{\mathrm{e}}^{2}$ \\
\hline \multirow{3}{*}{$\begin{array}{l}\text { Dentro de } \\
\text { parcelas }\end{array}$} & $k^{2}$ & & \\
\hline & $\Sigma$ & & \\
\hline & $i=1 \quad(\bar{n}-1)$ & $Q_{3}$ & $\sigma \stackrel{2}{\mathrm{~d}}$ \\
\hline
\end{tabular}

onde: $Q M=$ quadrado mëdio; $E(Q M)=$ esperança do quadrado mëdio; $\sigma_{\mathrm{p}}^{2}=$ variância entre progênies ao ñvel de plantas; $\sigma_{\mathrm{e}}^{2}=$ variância entre parcelas; $\sigma_{\mathrm{d}}^{2}=$ variância dentro de parcelas; $\overline{\mathrm{n}}=$ número de plantas por parcela (mêdia harmônica); $k=$ fator do lätice; $r=$ repetições.

A anâlise da variância para sobrevivência, com dados de totais de parcelas, teve a mesma estrutura daquelas com médias de parcelas, exceto no que se refere à variâncía do erro, que conteve, nesse caso, tambëm a variância dentro de parcelas, sem a possibilidade de seu isolamento.

O valor de F para progênies ajustadas, no ca so do lâtice, foi obtido atravês da correção da soma de qua drados para esta fonte de variação e testando-se o mesmo con tra o erro efetivo.

Os coeficientes de variação experimentais $\left(\mathrm{CV}_{\text {exp }}\right)$ das anâlises da variância foram calculados a partir do quadrado médio do erro efetivo das anâlises em látice, e 
do quadrado médio do erro entre parcelas das anâlises em blo cos ao acaso, e foram considerados como o principal parâmetro indicador da eficiência estatística das análises.

\subsubsection{ANÁLISES DA VARIÂNCIA CONJUNTAS PARA ESPAÇA- MENTOS E IDADES}

As anâlises da variância conjuntas para espa çamentos e idades foram efetuadas para as 169 progênies, ut $\underline{i}$ 1izando, segundo COCHRAN e COX (1965), os totais de tratamen tos ajustados das análises individuais em lätice. Oerro uti lizado nessas análises foi o erro médio entre os erros efeti vos das análises individuais consicieradas.

Adotou-se o modelo matemático referente à anâa lise conjunta para espaçamentos e progênies, considerados co mo de efeitos fixo e aleatörio, respectivamente, utilizado por KAGEYAMA (1983) e que ficou:

$$
\bar{y}_{i j k m}=\mu+t_{i}+s_{k}+(t s)_{i k}+\bar{e}_{i j k}+\bar{d}_{i j k m}
$$

onde :

$\bar{y}_{i j k m}$ é a observação feita no indivíduo m, do tratamento i, no bloco j, do espaçamento k;

$\mu \quad$ è a mẻdia geral;

$t_{i} \quad \bar{e}$ o efeito de tratamento;

$\mathrm{s}_{\mathrm{k}} \quad \dot{\mathrm{e}}$ o efeito do espaçamento; 
(ts) ik é o efeito da interação do tratamento por espaçamento; $\bar{e}_{i j k} \quad \bar{e}$ o efeito do erróexperimental; e $\mathrm{d}_{i j k m}$ é o efeito dentro de parcelas.

A análise conjunta para idades, em cada espa çamento, com progênies e idades, consideradas como efeitos aleatório e fixo, respectivamente, fica, segundo KAGEYAMA (1983), como sendo:

$$
\bar{y}_{i j k m}=\mu+t_{i}+a_{k}+(t a)_{i k}+\bar{e}_{i j k}+\bar{d}_{i j k m}
$$

onde:

$\bar{y}_{i j k m}$ é a observação feita no indivíduo m, do tratamento $i$, no bloco $j$, da idade $k$;

$\mu \quad$ é a média geral;

$t_{i} \quad$ é o efeito de tratamento;

$a_{k} \quad$ é o efeito da idađe;

$\left(\right.$ ta) ${ }_{i k}$ é o efeito de interação de tratamentos por idades;

$\bar{e}_{i j k} \quad$ é o efeito do erro experimental; e

$a_{i j k m}$ é o efeito dentro de parcelas.

A estrutura das anâlises da variância conjun tas envolvendo os diferentes espaçamentos em cada idade, ou as vărias idades em cada espaçamento, ficou: 


\begin{tabular}{|c|c|c|c|}
\hline FV & GL & $\mathrm{QM}$ & $E(Q)$ \\
\hline $\begin{array}{l}\text { Blocos dentro de re } \\
\text { petições }\end{array}$ & $s(r-1)$ & $Q_{0}$ & $(1 / \bar{n}) \sigma_{\mathrm{d}}^{2}+\sigma_{\mathrm{e}}^{2}+\mathrm{p} \sigma_{\mathrm{b} / 1}^{2}$ \\
\hline $\begin{array}{l}\text { Espaçamentos ou ida } \\
\text { des }\end{array}$ & $s-1$ & $Q_{1}$ & $(1 / \bar{n}) \sigma_{\mathrm{d}}^{2}+\sigma_{\mathrm{e}}^{2}+r \sigma_{\mathrm{p} 1}^{2}+\mathrm{p} \sigma_{\mathrm{b}}^{2}+r p \sigma_{1}^{2}$ \\
\hline Progênies & $p-1$ & $Q_{2}$ & $(1 / \overline{\mathrm{n}}) \sigma_{\mathrm{d}}^{2}+\sigma_{\mathrm{e}}^{2}+r s \sigma_{\mathrm{p}}^{2}$ \\
\hline $\begin{array}{l}\text { Progênies x Espaça- } \\
\text { mentos ou idades }\end{array}$ & $(p-1)(s-1)$ & $Q_{3}$ & $(1 / \bar{n}) \sigma_{\mathrm{d}}^{2}+\sigma_{\mathrm{e}}^{2}+r \sigma_{\mathrm{p} 1}^{2}$ \\
\hline Erro Medio & $s(r-1)(p-1)$ & $\mathrm{Q}_{4}$ & $(1 / \bar{n}) \sigma_{\mathrm{d}}^{2}+\sigma_{\mathrm{e}}^{2}$ \\
\hline $\begin{array}{l}\text { Dentro de parce- } \\
\text { las }\end{array}$ & $\sum_{i=1}^{k^{2}}(n-1)$ & $Q_{5}$ & $\sigma_{\mathrm{d}}^{2}$ \\
\hline
\end{tabular}

onde:

$\sigma_{1}^{2} \quad \vec{e}$ a variância entre espaçamentos ou entre idades;

$\sigma_{\mathrm{p}}^{2} \quad$ è a variância entre progênies:

$\sigma_{\mathrm{p} 1}^{2}$ é a variância da interação de progênies por espaçamentas ou por idades;

$\sigma_{\mathrm{e}}^{2} \quad \overrightarrow{\mathrm{e}}$ a viriância entre parcelas;

$\sigma_{\mathrm{d}}^{2} \quad \bar{e}$ a variância dentro de parcelas;

$\bar{n}$ é o número de plantas por parcela (mêdia harmônica); $(n-1)$ é o nümero de graus de liberdade de cada parcela; e. $\sigma_{b}^{2} \quad$ é o efeito do bloco dentro de espaçamentos. 
KAGEYAMA (1983) salienta que a anâlise da variância conjunta para espaçamentos permite a estimação da va riância da interação de progênies por espaçamentos, que esta ria confundida com a variância devida a tratamentos na análi se individual. Se os espaçamentos abrangidos pelo ensaio representam de fato um ambiente adequado à espécie e às famí lias, a variância genética devida a tratamentos, sem a devida à interação com espaçamentos, seria a mais indicada para expressar de fato a quantidade de variação disponível ao melhoramento.

\subsubsection{ANÄLISE DA COVARIÂNCIA ENTRE IDADES PARA CADA CARACTERÍSTICA E ENTRE CARACTERÍSTICAS PARA CADA IDADE}

A anâlise da covariância entre pares de idades, para uma determinada característica e espaçamento, pos sibilitou a obtenção de parâmetros que quantificam a associa ção entre diferentes idades, sendo importante para o conheci mento do desenvolvimento das plantas em função à idade.

A determinação dos produtos médios (PM), a partir da ailälise da variância, foi efetuada utilizando- se os dados de cada idade para as características de altura, di âmetro, ärea basal e volume cilîndrico. o produto mëdio para progênies e para o erro experimental foi obtido atravês do 
método proposto por Kempthorne (1966), citado por GERALDI (1977), utilizando-se os réspectivos quadrados médios das análises da variância da respectiva característica e da soma tória das características consideradas.

A estrutura da análise da covariância para ca da par de características de créscimento para uma idade e es paçamento, e para cada par de idades para uma característica de crescimento, segundo os esquemas em látice e blocos ao acaso, ficou:

\begin{tabular}{|c|c|c|c|}
\hline FV & GL & $\mathrm{PM}$ & $\mathrm{E} .(\mathrm{PM})$ \\
\hline Progênies ajustadas & $k^{2}-1$ & $\mathrm{P}_{1}$ & $(1 / \bar{n}) \operatorname{Cov}_{d}+\operatorname{Cov}_{e}+r \operatorname{Cov}_{p}$ \\
\hline Erro efetivo & $(\mathrm{rk}-\mathrm{k}-1)(\mathrm{k}-1)$ & $\mathrm{P}_{2}$ & $(1 / \bar{n}) \operatorname{Cov}_{\mathrm{d}}+\operatorname{Cov}_{\mathrm{e}}$ \\
\hline Progênies não ajustadas & $\mathrm{p}-1$ & $\mathrm{P}_{1}$ & $(1 / \bar{n}) \operatorname{Cov}_{d}+\operatorname{Cov}_{e}+\mathrm{rCov}_{p}$ \\
\hline Erro (BAA) & $(\mathrm{r}-1)(\mathrm{p}-1)$ & $\mathrm{P}_{2}$ & $(1 / \bar{n}) \operatorname{Cov}_{d}+\operatorname{Cov}_{e}$ \\
\hline
\end{tabular}

onde:

$\mathrm{PM}=$ produto mêdio;

$E(P M)=$ esperança do produto médio;

$\operatorname{Cov}_{\mathrm{p}}=$ covariância entre progênies:

$\mathrm{Cov}_{\mathrm{e}}=$ covariância do erro entre parcelas;

$\operatorname{Cov}_{\mathrm{d}}=$ covariância dentro de parcelas;

$\bar{n} \quad=$ número de plantas por parcela (mểia harmônica);

$\mathrm{k}$ = fator do lätice;

$\mathrm{r} \quad=$ número de repetições. 
Da mesma forma, a anâlise da covariância foi também aplicada entre pareś de características de crescimen to para cada espaçamento e idade.

\subsubsection{ESTIMATIVAS DOS PARÂMETROS GENÉTICOS}

A estimativa das variâncias genéticas e ambientais, e de parâmetros afins, foi obtida através dos esque mas das análises da variância individuais em lâtice e em blo cos ao acaso, pela decomposição do quadrado médio em suas es peranças matemáticas.

Para estimar as variâncias genéticas no caso da utilização do látice, o quadrado médio de progênies foi obtido através dos totais de tratamentos ajustados. O quadra do médio do erro utilizado foi o erro efetivo.

A variância genëtica entre progênies $\left(\sigma_{p}^{2}\right)$, a variância devida ao erro entre parcelas $\left(\sigma_{\mathrm{e}}^{2}\right)$ e a variância dentro de parcelas $\left(\sigma_{\mathrm{d}}^{2}\right)$, para cada característica e idade, considerando-se um só espaçamento, foram obtidas através de decompos:_ção dos componentes da variância total.

A variância dentro de parcelas foi estimada in dependenteriente da anālise da variância, através da relação entre as somatórias das somas dos quadrados dos desvios e dos graus de liberdade do número de plantas dentro das parce las (mêdia harmônica), segundo a seguinte expressão: 


$$
\sigma_{\mathrm{d}}^{2} \frac{\sum \mathrm{S} \mathrm{Q} \mathrm{D}}{\sum \mathrm{GL}\left(\mathrm{n}^{\circ} \text { de plantas }\right)} \text { onde: }
$$

$\mathrm{SQD}=$ soma dos quadrados dos desvios; $\mathrm{GL}=$ graus de liberdade do nümero de plantas por parcela; $\sigma_{\mathrm{d}}^{2}=$ variância dentro de parcelas.

$$
\text { A variância devida ao erro entre parcelas }\left(\sigma_{e}^{2}\right)
$$
e a variância devida a progênies $\left(\sigma_{p}^{2}\right)$ foram calculadas como a seguir:

$$
\begin{aligned}
& \sigma_{\mathrm{e}}^{2}=\mathrm{Q}_{2}-\mathrm{Q}_{3} / \mathrm{n} \\
& \sigma_{\mathrm{p}}^{2}=\frac{\mathrm{Q}_{1}-\mathrm{Q}_{2}}{\mathrm{r}}
\end{aligned}
$$

Os erros associados às variâncias entre progê nies foram estimados a partir das análises da variância, segundo o modelo proposto por Vello e Vencovsky (1974), citados por KAGEYAMA (1980), mostrado a seguir:

$$
s\left(\hat{\sigma}_{p}^{2}\right)=\sqrt{-\frac{2}{k^{2} r^{2}}\left(\frac{Q^{2} 1}{g_{1}+2} \quad \frac{Q^{2} 2}{g_{2}+2}\right)}
$$

onde :

$s\left(\hat{\sigma}_{p}^{2}\right)=$ é o erro associado à estimativa da variância entre progênies de meios-irmãos;

$\bar{k}=\quad e ́$ o número médio de plantas por parcela;

$\mathrm{r}=\overrightarrow{\mathrm{e}} \mathrm{o}$ nümero de repetiçōes;

$Q_{1}$ e $Q_{2}=$ são os quadrados médios para progênies e para o e ro experimental, respectivamente; 
As estimativas da variância aditiva $\left(\sigma_{A}^{2}\right)$, variância fenotípica $\left(\sigma_{\mathrm{F}}^{2}\right)$ e á variância fenotípica entre médias de familias $\left(\sigma_{F}^{2}\right)$ foram obtidas como a seguir:

$$
\begin{aligned}
& \sigma_{\mathrm{A}}^{2}=4 \sigma_{\mathrm{p}}^{2} \\
& \sigma_{\overline{\mathrm{F}}}^{2}=\sigma_{\mathrm{p}}^{2}+\sigma_{\mathrm{e}}^{2 / r}+\sigma_{\mathrm{d}}^{2} / \mathrm{nr} \\
& \sigma_{\mathrm{F}}^{2}=\sigma_{\mathrm{p}}^{2}+\sigma_{\mathrm{e}}^{2}+\sigma_{\mathrm{d}}^{2}
\end{aligned}
$$

A partir das estimativas das variâncias gene ticas e não genéticas, foram estimados os coeficientes de herdabilidade e da variação. Considerou-se no caso, as progê nies como sendo de meios-irmãos e que, como levantam VENCOV KY (1978) e KAGEYAMA (1980, 1983), a variância genética entre progênjes $\left(\sigma_{p}^{2}\right)$ contém, nesse caso, $1 / 4$ da variância genê tica aditiva da população. O coeficiente de herdabilidade, no sentido restrito, ao nível de plantas, para um só local, fi ca então:

$$
h^{2}=\frac{4 \sigma_{p}^{2}}{\sigma_{p}^{2}+\sigma_{e}^{2}+\frac{\sigma_{g}}{2}}
$$

Os coeficientes de variação genética, da variância do erro, dentro de parcelas e fenotípica, foram estí mados pela expressão abaixo, todos em porcentagem em relação à média $(\bar{X})$ : 


$$
\begin{aligned}
& \mathrm{CV}_{\mathrm{g}}\left(\begin{array}{l}
\% \\
0
\end{array}\right)=\frac{\sigma_{\mathrm{p}}}{\overline{\mathrm{x}}} \cdot 100 \\
& \mathrm{CV}_{\mathrm{e}}\left(\begin{array}{l}
0 \\
0
\end{array}\right)=\frac{\sigma_{\mathrm{e}}}{\overline{\mathrm{X}}} \cdot 100 \\
& \mathrm{CV}_{\mathrm{d}}\left(\begin{array}{l}
0 \\
0
\end{array}\right)=\frac{\sigma_{\mathrm{d}}}{\overline{\mathrm{X}}} \cdot 100 \\
& \mathrm{CV}_{\mathrm{f}}\left(\begin{array}{l}
0 \\
0
\end{array}\right)=\frac{\sigma_{\mathrm{F}}}{\overline{\mathrm{X}}} \cdot 100
\end{aligned}
$$

onde :

$\sigma_{p} \sqrt{\text { variância devida a progênies }}$

$\sigma_{e} \sqrt{\text { variância devida ao erro entre parcelas }}$

$\sigma_{d} \sqrt{\text { variância dentro de parcelas; }}$

$\sigma_{F} \sqrt{\text { variância fenotípica; }}$ e

$\overline{\mathrm{X}}$ médià geral do experimento.

Considerando que esses parâmetros da população de progênies são todos expressos em termos porcentuais em relação à média, os mesmos poderäo ser comparados, permitindo a anālise em termos de variação com o espaçamento e com a idade.

A associação entre as idades nos ensaios foi obtida através dos coeficientes de correlação genética e fenotípica. Os coeficientes de correlação foram estimados atra vês dos componentes da covariância, que foram obtidos, por sua vez, da esperança dos produtos médios da anảlise de cova 
riância e dos componentes da variância das anâlises de variância, efetuadas para as progênies estudadas.

Para cada característica, nas diferentes idades, foram estimadas a variância e a covariância entre progê nies, a variância e a covariância devidas ao erro experimental e a variância e covarianncia fenotípicas, que foram utili zadas para estimar os dois tipos de coeficientes de correlação: o coeficiente de correlação genética aditiva $\left(\mathrm{r}_{G}\right)$ e o coeficiente de correlação fenotípica ao nível de médias de familias, que foram estimados, segundo KAGEYAMA (1983), como a seguir:

O coeficiente de correlação genética aditiva $\left(\mathrm{r}_{\mathrm{G}}\right)$ entre duas idades para uma dada caracteristica, foi estimado por:

$$
r_{G(x, y)}=\frac{\operatorname{Cov}_{p(x, y)}}{\sigma_{p(x)} \cdot \sigma_{p(y)}} \text {, onde: }
$$

$\operatorname{Cov}_{p(x, y)}$ a covariância devida a progênies entre as idades ou caracteristicas $x$ e $y$;

$\sigma_{p(x)}$ e $\sigma_{p(y)}$ os desvios entre progênies para as idades ou características $x$ e $y$; e

$\mathrm{r}_{\mathrm{G}}(\mathrm{x}, \mathrm{y})$ o coeficiente de correlação genética aditiva entre as idades ou características ( $x$ e y), respec tivamente. 
O coeficiente de correlação fenotípica entre duas idades, ao nível de médias de progênies, para uma dada característica, ou entre características para uma idade, foi estimado por:

$$
r_{F(x, y)}=\frac{\operatorname{Cov}_{f(x, y)}}{\sigma_{f(x)} \cdot \sigma_{f(y)}} \text {, onde: }
$$

$r_{F(x, y)}$ é o coeficiente de correlação fenotípica entre as idades ou características, $x$ e $y$;

$\operatorname{Cov}_{f(x, y)}$ é a covariância fenotípica entre as idades ou características $x$ e $y$; e

$\sigma_{f(x)}$ e $\sigma_{f(y)}$ são os desvios fenotípicos para as idades ou características $\mathrm{x}$ e $\mathrm{y}$, respectivamente.

Para o caso da correlação genêtica " aditiva, considerou-se como verdadeira a relação de meios-irmãos para as progênies e, à semelhança de variância entre progênies, a covariância devida a progênies contém $1 / 4$ da covariância aditiva da população.

A correlação genética ou fenotípica entre ida des pode ser considerada, como salienta KAGEYAMA (1983), como se fosse para duas características quaisquer, tais como altura e diâmetro, volume e forma, etc., relatando que no ca so, as idades estudadas foram consideradas, em princípio, co mo diferences características no que concerne ao controle ge nético, conforme foi colocado por Toda (1972), citado pelo autor. 
E importante salientar que, no presente caso, em função da não casualização completa para o espaçamento $3,0 \times 2,0$ e $3,0 \times 1,0 \mathrm{~m}$, as correlações genéticas estimadas não podem ser consideradas como puras, jã que elas incluem tanto covariâncias genéticas como ambientais, não sendo possível o seu isolamento. Por esse fato, as correlações genéti cas entre espaçamentos, para uma característica e idade, devem ser consideradas com as devidas reservas. Deve-se colo car que as correlações genéticas, assim estimadas, seriam, na verdade, o limite superior desses valores. 


\section{RESULTADOS E DISCUSSÃO}

\subsection{Crescimento das Progênies}

Os resultados de sobrevivência e de crescimento en altura, diâmetro, área basal e volume cilíndrico das progenies de Eucalyptus saligna Smith, nas três idades e nos dois espaçamentos avaliados, são apresentados e discutidos a seguir.

\section{$4,1,1$, SOBREVIVÊNCIA DAS PROGÊNIES}

A sobrevivência média das progênies de Eucalyptus saligna Smith, em função do espaçamento e idade, é a presentada na tabela 5 , a seguir: 
Tabela 5 - Sobrevivência das progênies de Eucalyptus saligna Smith nos dois espaçamentos testados, nas três idades avaliadas.

\begin{tabular}{cccc}
\hline \multirow{2}{*}{$\begin{array}{c}\text { ESPACAMENTOS } \\
\text { (m) }\end{array}$} & \multicolumn{3}{c}{ SOBREVIVENCIA $\left(\begin{array}{l}0 \\
0\end{array}\right)^{*}$} \\
\cline { 2 - 4 } $3,0 \times 1,0$ & 97,8 & 96,71 & 96,01 \\
$3,0 \times 2,0$ & & 99,20 & 98,40 \\
\hline
\end{tabular}

* Dados sem transformação.

Pode-se observar que os dados de sobrevivência dos ensaios, expressos como médias de parcela por parcela, re velaram valores altos para a maioria das progênies testadas, nas diferentes idades e nos espaçamentos considerados, sendu esses valores ligeiramente maiores para as progênies sob espaçamento mais amplo.

As anâlises da variância em lâtice não revela ram a existência de significância para a sobrevivência das progênies crescendo no espaçamento de $3,0 \times 2,0 \mathrm{~m}$, enquanto que para o ensaio ao espaçamento mais apertado o teste F mos trou a existência de significâncıa entre as progênies ao nível de $1 \%$.

No espaçamento de $3,0 \times 1,0 \mathrm{~m}$, além da morta lidade natural atribuída a fatores aleatórios, houve tambêm uma mortalidade adicional proveniente da competição entre as árvores, a partir do momento em que se verificou a plena ocu 
pação da área disponível para o crescimento, o que ocorreu num espaço menor de tempo d́o que para o espaçamento de $3,0 \mathrm{x}$ $2,0 \mathrm{~m}$.

A julgar pelos valores de F (Tabela 6) a variação genética entre progênies para a sobrevivência de plantas foi mais expressiva no espaçamento menor; o que pode estar refletindo a maior mortalidade ocorrida nesse espaçamento, causada pela maior competição entre as plantas, e também devida a causas fortuitas.

Os resultados obtidos da tabela 5 indicam que em todas as idades estudadas o espaçamento influenciou a sobrevivência das ârvores, os maiores nîveis de sobrevivência correspondendo sempre ao espaçamento mais amplo. Esses resul tados são concordantes com aqueles obtidos por vârios autores. GUIMARAES (1965) verificou para o Eucalyptus saligna Smith, aos 8 anos de idade, a existência de uma tendência para aumentar a mortalidade das árvores à medida que os espaços di minuiam. BALLONI e SIMOES (1980) mostraram que o Eucalyptus saligna Smith apresentava, já a uma idade de 6 anos e 2 meses, maiores percentagens de falhas, mortes e árvores domina das em espaçamentos mais apertados, quando comparado com o Eucalyptus grandis Hill Ex Maiden, o qual apresentou tambëm maiores percentagens de mortalidade, falhas e ārvores domina das, nos espaçamentos mais apertados; COUTO (1977) tambëm ve rificou o fato anterior para Eucalyptus urophylla S.T.Blake. Pode-se então comentar o fato de que muitas espécies de Euca 
lyptus apresentam a tendência de que quanto mais apertada $\vec{e}$ a distância do plantio, maíor é a eliminação de indivíduos, motivada naturalmente pela concorrência mais acirrada entre as ārvores.

Na figura 2, pode-se observar o comportamento das progênies para sobrevivência, considerando-se a idade e o espaçamento.

Sobrevivència

$(\%)$

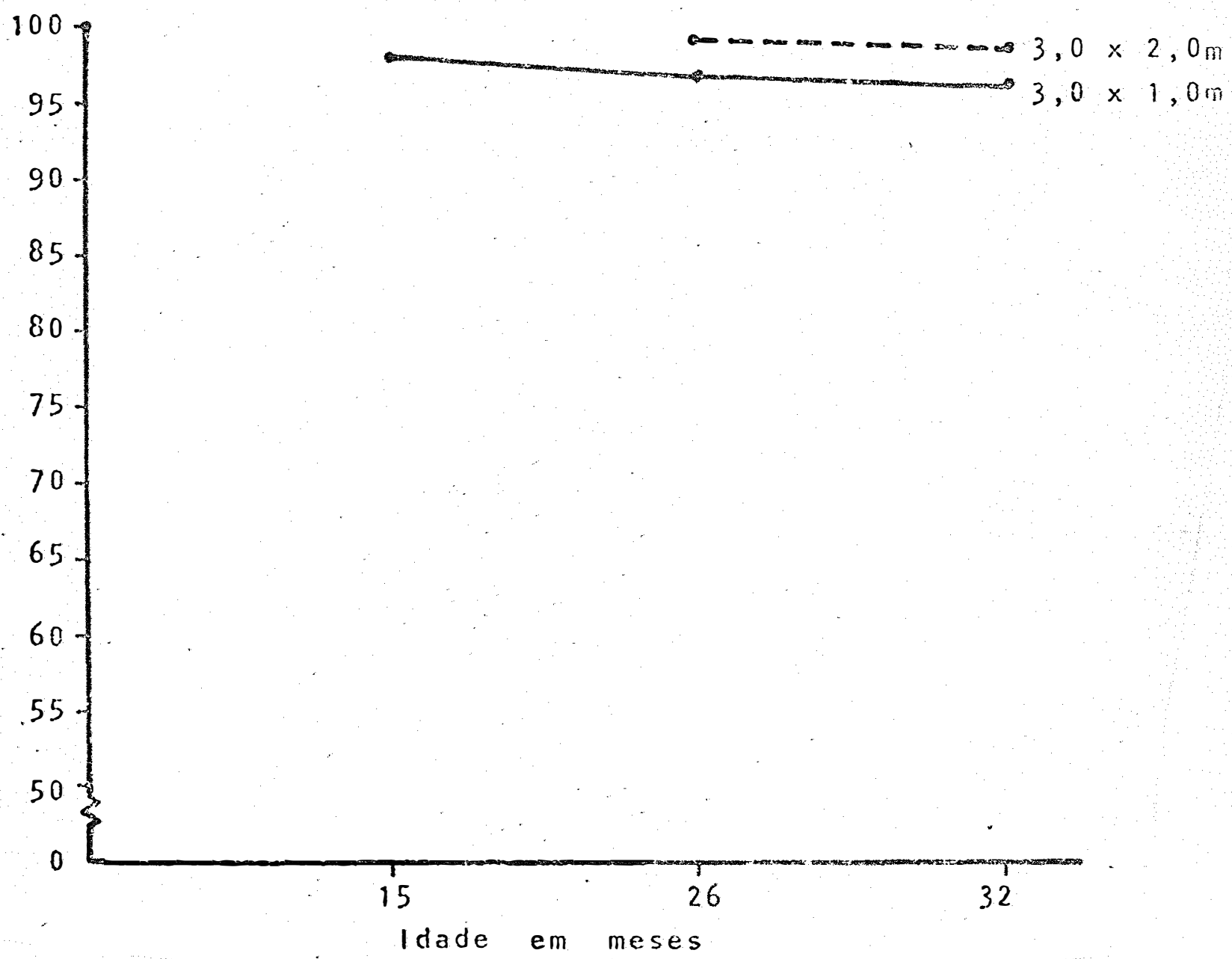

Figura 2 - Evolução da sobrevivência média das progênies em função da idade e do espaçamento. 


\subsubsection{CRESCIMENTO EM ALTURA}

Os resultados de crescimento em altura, DAP, ārea basal e volume cilíndrico, obtidos para as progênies nos dois espaçamentos, assim como os coeficientes de variação ex perimental, eficiência do láticé e valores de F, obtidos nas análises da variância individuais, são apresentados na tabela 6 . As médias apresentadas se referem aos tratamentos ajus tados das anālises em lätice.

As médias gerais dos ensaios revelaram um cres cimento em altura bastante vigoroso para as progênies, apresentando mêdias aos 15,26 e 32 meses de $6,98 \mathrm{~m}, 10,18 \mathrm{~m}$ e $10,71 \mathrm{~m}$, respectivamente, para o espaçamento de $3,0 \times 1,0 \mathrm{~m}$. Para o espaçamento de $3,0 \times 2,0 \mathrm{~m}$, as médias apresentadasnas idades de 26 e 32 meses foram de $9,78 \mathrm{~m}$ e $10,53 \mathrm{~m}$, respectivamente.

0 incremento médio anual para o crescimentc em altura aos 32 meses de idade, que foi calculado a partir das médias de tratamentos ajustadas, atingiu um valor de 4,02 $\mathrm{m}$ para as progênies sob espaçamento de $3,0 \times 1,0 \mathrm{~m}$ e de 3,95 m para o de $3,0 \times 2,0 \mathrm{~m}$.

A amplitude do crescimento, observada entre as progênies para todas as caracterjsticas estudadas, e que mostra a magnitude da variação observada, é mostrada na tabe la 7 .

A amplitude observada para o crescimento em 
altura das progênies aos 32 meses de idade, foi de $3,17 \mathrm{~m}$ $(25,96 \%$ de diferença) para as progênies no espaçamento de $3,0 \times 1,0 \mathrm{~m}$ e de 4,22 $\mathrm{m}$ (34,65\% de diferença) no de $3,0 \times$ $2,0 \mathrm{~m}$, quando comparados aos crescimentos em altura da melhor e da pior progênie nesses espaçamentos. 


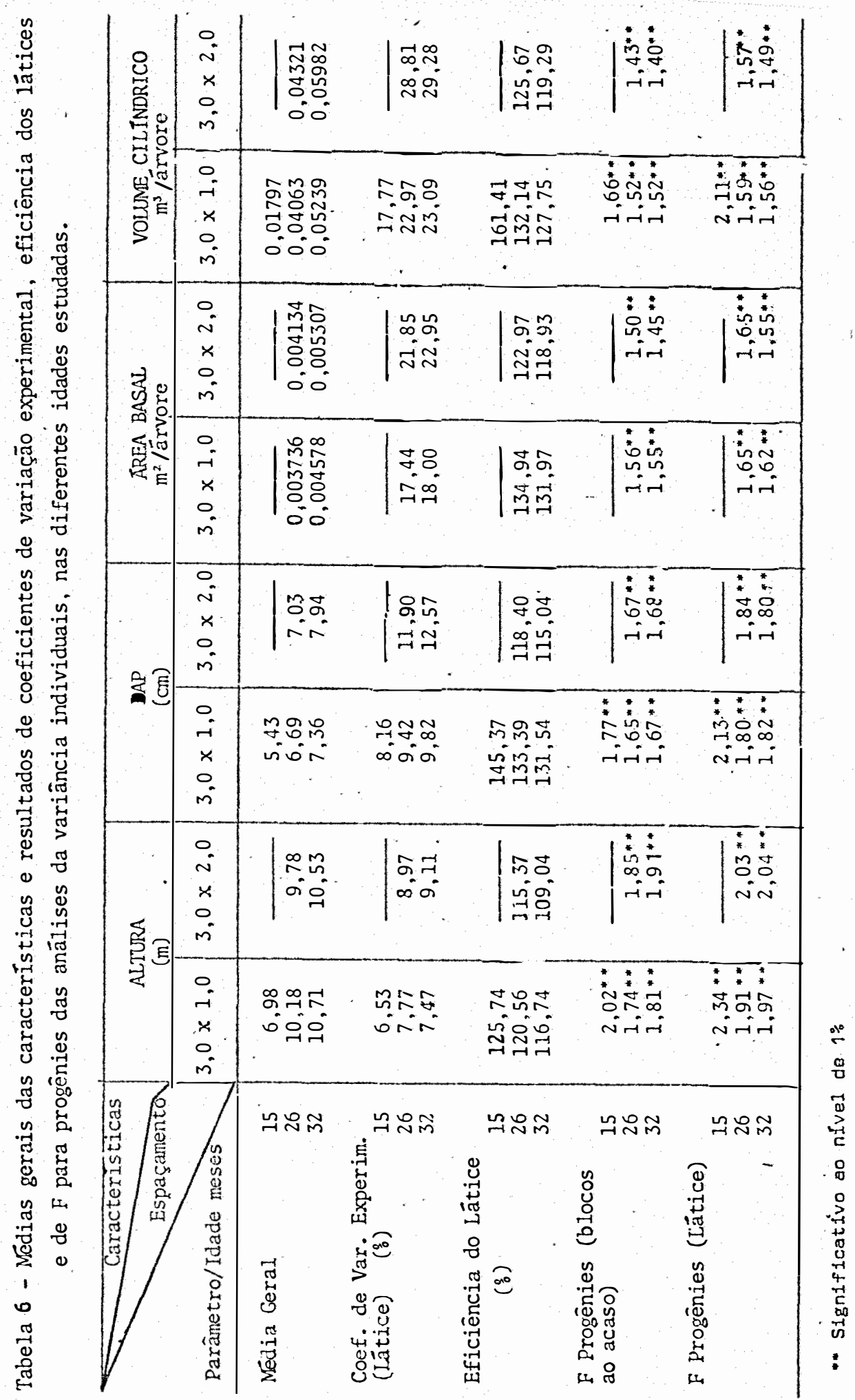


$\mathrm{Na}$ figura 3 , a seguir, pode-se observar a evo lução no crescimento em altura das progênies, considerandose os espaçamentos testados e as idades avaliadas.

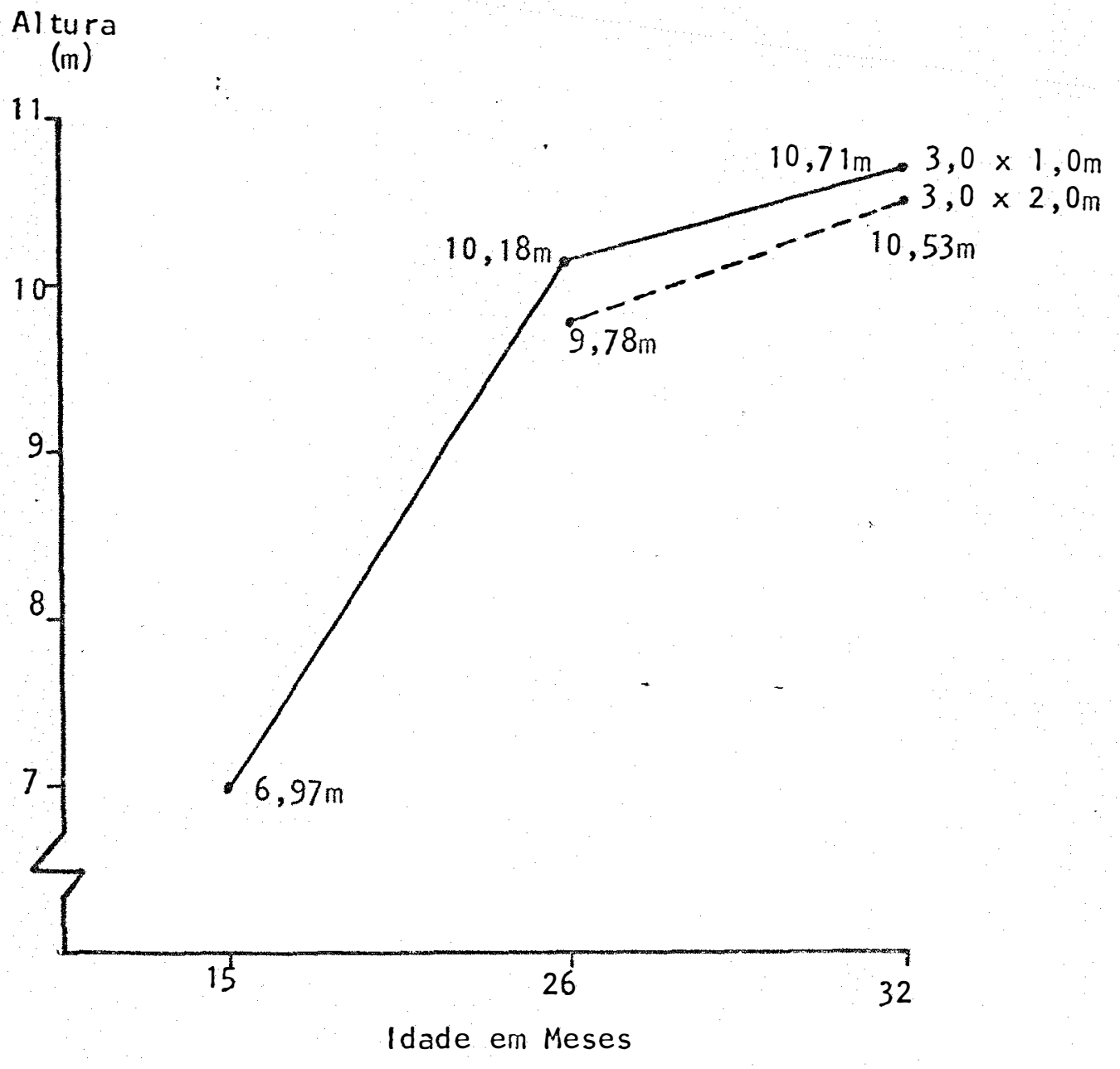

Figura 3 - Evolução no crescimento mêdio em altura das progênies, em fun ção da idade e do espaçamento.

Os coeficientes de variação experimental foram semelhantes para os dois espaçamentos, nas diferentes $\underline{i}$ dades avaliadas. Esses valores foram de $6,53 \%, 7,77 \%$ e $7,47 \%$ para as idades de 15,26 e 32 meses, respectivamente, dentro 
do espaçamento de 3,0 x $1,0 \mathrm{~m}$, e de $8,97 \%$ e $9,11 \%$ nas idades de 26 e 32 meses, respectiv́amente, no espaçamento de $3,0 x$ $2,0 \mathrm{~m}$.

As eficiências dos látices apresentaram quatro valores acịma de $115 \%$ e um só valor de 109,04\%, pelo qual e, concordando com SNYDER (1966)' e MIRANDA FILHO (1978), foi justificada plenamente a utilização desse delineamento experimental no caso em questão.

A variação genêtica entre progênies para altu ra de plantas foi muito semelhante para os dois espaçamentos a julgar pelos valores do teste $F$ ohtidos nas análises da va riância . 


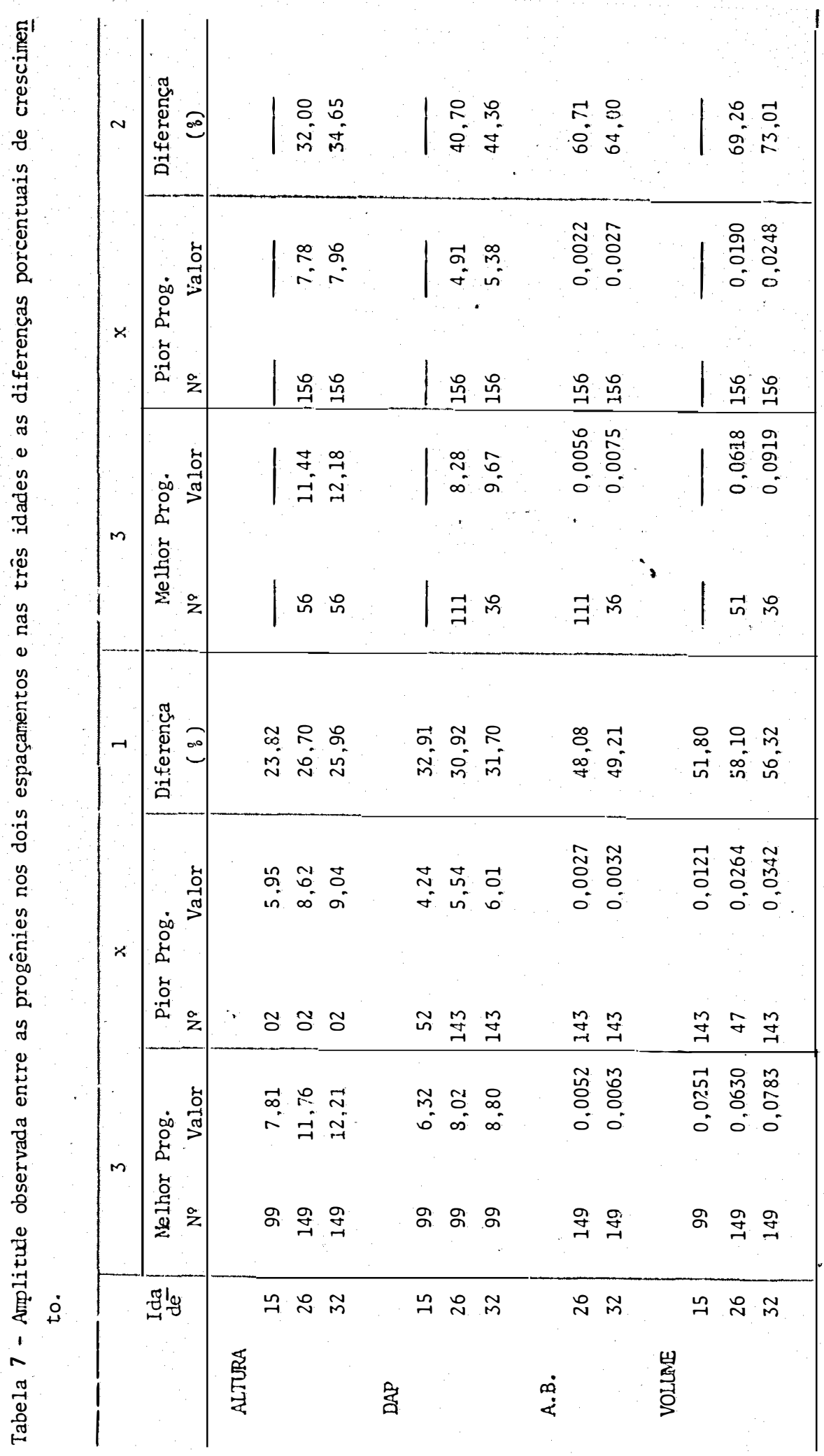


O crescimento em altura das progênies foi mais expressivo no espaçamento $3,0 \times 1,0 \mathrm{~m}$ do que no espaçamento mais amplo, o qual pode-se observar nas curvas de crescimento em altura da figura 3 . Essa resposta pode ser devida a que depois do desbaste efetuado, à idade de 17 meses, as pro gênies no espaçamento de 3,0 x 2,0 $\mathrm{m}$ tenderam a se incrementar mais em diâmetro do que em altura. Segundo Johston et alii, citados por COUTO (1977), a altura média é muito sensí vel a qualquer forma de desbaste ou mortalidade natural, que geralmente tendem a eliminar as ärvores menores no povoamento. Nesse caso, as ärvores remanescentes irão dispor de mais espaço para crescer e, consequentemente, haverā um incremento na taxa de crescimento em diâmetro, resultando num diâme tro médio maior para o povoamento. Por sua vez, MATHESon e RAYMOND (1934a) encontraram para Pinus radiata D. Don, que o desbaste, quando efetuado em fileiras ou pela remoção casualizada das ärvores, não afetou as estimativas das variâncias embora tenha-se incrementado o exro padrão das estimativas de herdabilidade. Os autores também verificaram que as estimativas de herdabilidade não apresentaram grandes diferenças nas estimativas feitas na época do desbaste e aos 3 e 5 anos depois de efetuado.

E importante salientar o fato de que o desbas te efetuado no ensaio de progênies, à idade de 17 meses, foi realizado utilizando-se o método sistemâtico ou mecânico, não existindo, portanto, nenhuma seleção das ârvores dentro 
das parcelas.

Considerandó-se os incrementos periôdicos de crescimento em altura dos ūltimos 6 meses de crescimento $(0,64 \mathrm{~cm}$ para $3,0 \times 2,0 \mathrm{~m} \mathrm{e} 0,45 \mathrm{~cm}$ para $3,0 \times 1,0 \mathrm{~m})$ e os valores médios de altura nos 26 e 32 meses de idade, para am bos os espaçamentos, percebe-se que no período compreendido entre ambas as idades, o incremento em altura das progênies foi maior no espaçamento mais amplo. A diferença entre as duas idades consideradas foi de $0,95 \mathrm{~m}$ para o espaçamento de $3,0 \times 2,0 \mathrm{~m}$, enquanto que para o de $3,0 \times 1,0 \mathrm{~m}$ foi de 0,53 m, no mesmo período. Esses fatos sugerem que a altura média está sendo cada vez mais influenciada pelo espaçamento mais amplo, concordando com os resultados obtidos por diversos au tores, em que maiores valores para altura média dos povoamen tos correspondem aos espaçamentos mais amplos.

Assim, GUIMARAES (1960) encontrou que para Eu calyptus saligna Smith, a altura média do povoamento sofre a influência do espaçamento, sendo maior nas distâncias do plantio maiores. Da mesma forma, COELHO et alii (1970) con... cluiram que existindo uma correlação positiva entre diâmetro e altura, o espaçamento mais amplo favoreceria o crescimento em diâmetro, concorrendo tambēm para maior altura das árvores, que resulta em uma altura média mais elevada. BALLONi \& SIMOES (1980), por sua vez, verificaram também a tendênciá de incremento da altura média das ärvores de Eucalyptus gran dis Hill Ex Maiden e de E. saligna Smith, conforme o incre- 
mento do espaçamento. SIMOES e SPINA FRANÇA (1983) verificaram a mesma tendência para Eucalyptus saligna Smith, E. gran dis Hill Ex Maiden e E. urophylla E.T. Blake, aos 2,5 anos de idade.

MESKIMEN e FRANKLIN (1978) verificaram, parà Eucalyptus grandis Hill Ex Maiden, aos 7 anos e 3 meses, que não houve diferenças na altura mêdia das ârvores, nos quatro espaçamentos testados, enquanto que o diâmetro foi diretamen te influenciado pelo espaçamento. Por slia vez, REzENDE et alii (1980) não encontraram diferenças significativas para as alturas mêdias de Eucalyptus saligna Smith e E. grandis Hill Ex Maiden. COELHO et alii (1970) não encontraram açäo positi va dos espaçamentos sobre a altura média para Eucaluptus saligna Smith, E. alba Reinw e E. propinqua Deane ex Maiden, embora os autores relatem que os espaçamentos influiram posi. tivamente nos crescimentos em altura mëdia e em diāmetro. Pa ra o E. grandis Hill Ex Maiden, FISHWICK (1976) ressaltou o fato de que, em sítios de boa qualidade, o espaçamento tem pouca influência sobre as alturas midias principais, ainda que muitas pesquisas indiquem leves aumentos em altura com espaçameıtos crescentes.

Por sua vez, KAGEYAMA (1986) aponta'a hetero geneidade das respostas das espécjes face ao espaçamento, as sinalando uma ampla gama de resultados e verificando a existência de uma tendência para a classificaçäo das espécies quanto à sua resposta a maior ou menor quantidade de luz. 0 
autor ressalta o fato de que as características e exigências das espécies dos diferentes estägios sucessionais não sãopor mero acaso e que devem ser consideradas no planejamento das plantações. O autor comenta, ainda, que apesar das espécies de Eucalyptus terem um comportamento tipicamente de pioneiras, algumas espécies mostram maior efeito em relação ao es paçamento do que outras.

\subsubsection{CRESCIMENTO EM DIÄMETRO DAS PROGÊNIES}

O crescimento em diâmetro seguiu a mesma ten dência do crescimento em altura das plantas. As médias gerais dos ensaios para diâmetro de plantas revelaram um crescimen to vigoroso, apresentando mëdias aos 15,26 e 32 meses de idade de $5,43 \mathrm{~cm}, 6,69 \mathrm{~cm}$ e $7,36 \mathrm{~cm}$, respectivamente, para o espaçamento de $3,0 \times 1,0 \mathrm{~m}$, e de $7,03 \mathrm{~cm} \mathrm{e} 7,94 \mathrm{~cm}$ nas idades d.e 25 e 32 meses, respectivamente, para o espaçamento de $3,0 \times 2,0, \mathrm{~m}$.

A amplitude observada no crescimento em diâme tro, quardo comparadas a melhor e a pior progênie, para um espaçamento e idade, apresentou a tendência de se incrementar conforme o aumento da idade. As diferenças foram maiores

no espaçamento de $3,0 \times 2,0 \mathrm{~m}$. Aos 32 meses de idade a amplí tude atingiu valores de $2,79 \mathrm{~cm}$ para $3,0 \times 1,0 \mathrm{~m}$ e de 4,29 cm para o de $3,0 \times 2,0 \mathrm{~m}$, que equivalem a $31,70 \%$ e $44,36:$ de 
diferença no crescimento em diāmetro para esses espaçamentos, respectivamente (tabela 7 ):

As melhores progênies para a idade de 32 meses foram a $99 \mathrm{com} 8,02 \mathrm{~cm}$ e a $36 \mathrm{com} 9,67$; as piores foram a $143 \mathrm{com} 5,54 \mathrm{~cm}$ e a $156 \mathrm{com} 5,38 \mathrm{~cm}$, para os espaçamentos de $3,0 \times 1,0$ e $3,0 \times 2,0 \mathrm{~m}$, respectivamente.

Os coeficientes de variação experimental apre sentaram um comportamento similar a aqueles obtidos para a1tura de plantas, atingindo valores de $8,16 \%, 9,42 \%$ e $9,82 \%$ para as idades de 15,26 e 32 meses, respectivamente, no es paçamento de $3,0 \times 1,0 \mathrm{~m}$, e de $11,90 \%$ e $12,75 \%$ para as idades de 26 e 32 meses, respectivamente, no espaçamento $3,0 \mathrm{x}$ $2,0 \mathrm{~m}$.

As eficiências dos látices para a caracterís tica de diâmetro foram sempre superiores a $115 \%$, confirmando - se a validade da utilização deste delineamento experimental, segundo SNYDER (1966) e MIRANDA FILHO (1978).

Analisando-se os valores do teste F, obtidos nas análises da variância, pode-se perceber que a variação genética entre progênies para diâmetro, foi muito semelhante para os dois espaçamentos, embora o crescimento em diâmetro tenha sido ligeiramente mais expressivo no espaçamento de $3,0 \times 2,0 \mathrm{~m}$. O incremento médio anual em diâmetro, calculado aos 32 meses de idade, foi de $2,98 \mathrm{~cm}$ para o espaçamento de $3,0 \times 2,0 \mathrm{~m}$ e de $2,76 \mathrm{~cm}$ para o de $3,0 \times 1,0 \mathrm{~m}$.

$\mathrm{Na}$ figura 4, pode-se observar a evolução do 
crescimento em diâmetro em ambos os espaçamentos e nas três idades consideradas.

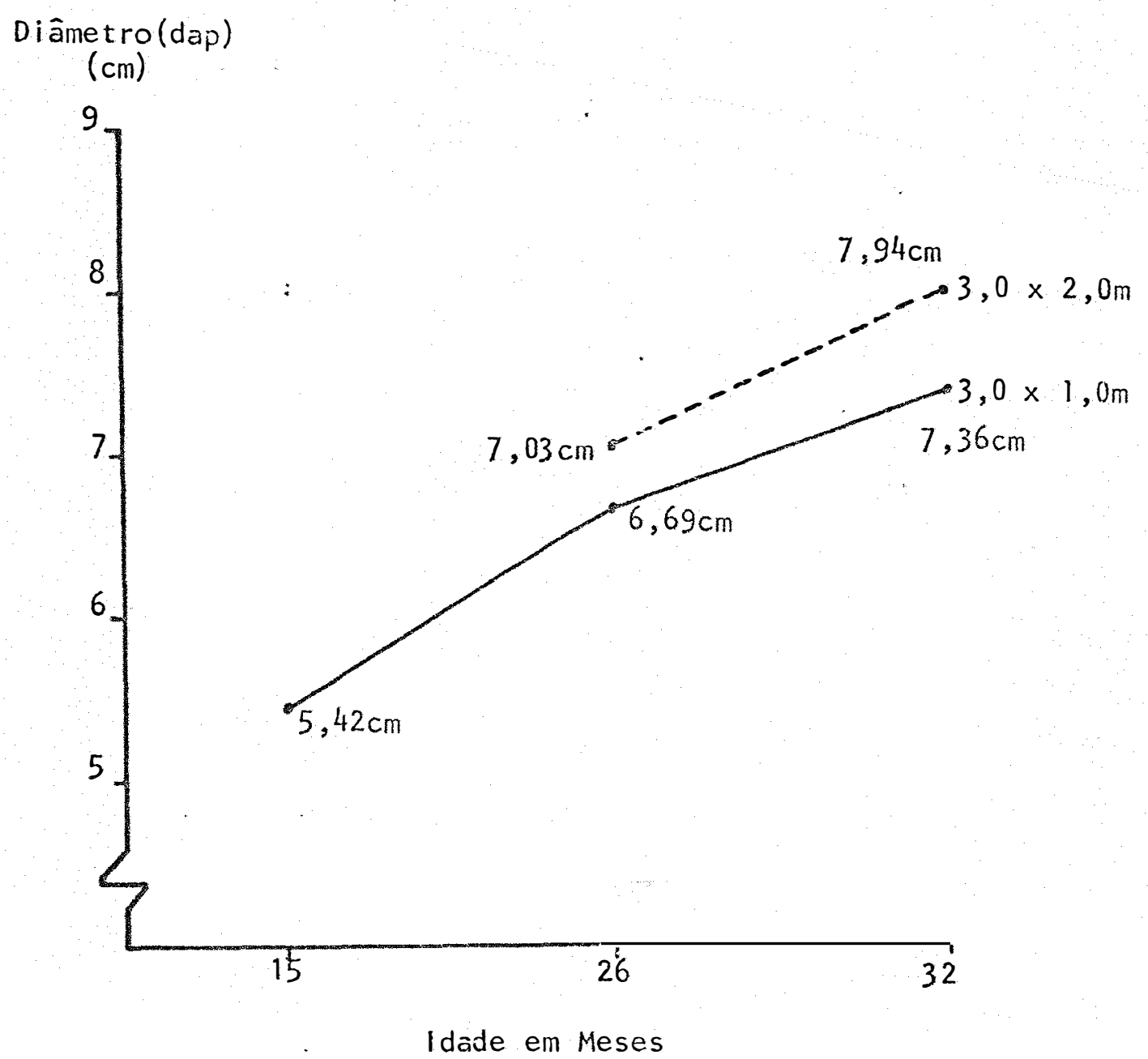

Figura 4 - Evolução no crescimento médio em DAP das progênies em função da idade e do espaçanento.

Os resultados obtidos para o comportamento do diâmetro concordam com os reportảos por värios autores, tais como os de GUIMARAES (1960), REZENDE et alii (1980), COE 
LHO et alii (1970), SIMÕES e SPINA-FRANÇA (1983), os quais verificaram que espaçamentós mais amplos correspondem a diâmetros médios maiores.

COELHO et alii (1970) concluíram para Eucalyp tus alba Reinw, E. grandis Hill Ex Maiden, E. propinqua e E. saligna Smith, testados em dois espaçamentos, que aos 24 me ses jâ era possível constatar-se os efeitos dos espaçamentos sobre o crescimento em diâmetro das árvores. A mesma espécie plantada em diferentes espaçamentos apresentava diferenças significativas, correspondendo maiores valores de diâmetros médios a espaçamentos mais amplos.

Por sua vez, KAGEYAMA (1986), estudando a res posta de espécies nativas e introduzidas com relação ao espa çamento, encontrou vârias e diferentes respostas, desde aque las espécies onde quanto maior o espaçamento, maior a cresci mento em altura e diâmetro, até aquelas em que ocorreu o fenômeno oposto ou quanto maior o espaçamento menor o crescimen to tanto em altura como em diâmetro: 0 autor salienta o fato de que nas espêcies de Eucalyptus, algumas mostram maior efeito em relação ao espaçamento do que outras, apresentandose desde aquelas tipicamente pioneiras até algumas que apre sentam características semelhantes às das espécies clímaxes. 


\subsubsection{CRESCIMENTO DAS PROGÊNIES EM AREA BASAL E VO- LUME CILÍNDŔICO}

A ārea basal e o volume cilíndrico foram obti dos atravês da somatória das âreas basais e dos volumes cilíndricos de cada um dos indivíduos que constituem a parcela, sendo dividido pelo nûmero das ârvores em cada parcela, pelo qual esses valores são expressos como sendo a ảrea basal individual média e o volume cilindrico individual médio, res pectivamente.

Considerando que o volume cilíndrico è compos to da altura e DAP das plantas, obviamente que as progênies que apresentarem menores e maiores diâmetros, com as mesmas tendências para altura, tenderão a apresentar volumes cilín dricos proporcionais às médias destas características. Simi lar comportamento deve-se esperar no caso da ảrea basal, a qual é função direta do diâmetro das plantas, pelo qual os valores ubtidos para esse parâmetro tenderão a apresentar âreas basais proporcionais a essas médias do diâmetro.

\subsubsection{AREA BASAL}

O incremento em ârea basal apresentou a mesma tendência do crescimento em diâmetro. As médias apresentadas nos dois ensaios foram de $0,003736 \mathrm{~m}^{3}$ e de $0,004578 \mathrm{~m}^{3}$, para 
as idades de 26 e 32 meses, respectivamente, dentro do espaçamento de $3,0 \times 1,0 \mathrm{~m}$. Paŕa o espaçamento de $3,0 \times 2,0 \mathrm{~m}$, as mêdias foram de $0,004134 \mathrm{~m}^{3}$ e de $0,005307 \mathrm{~m}^{3}$, para 26 e 32 meses de idade, respectivamente. A ârea basal foi calcula da considerando-se 9 plantas por parcela em 3,0 x 1,0 e 5 plantas em $3,0 \times 2,0 \mathrm{~m}$.

Considerando-se uma população média por hecta re de 3333 árvores e de 1667 árvores, nos espaçamentos de $3,0 \times 1,0$ e $3,0 \times 2,0 \mathrm{~m}$, respectivamente, os valores de ärea basal mëdia por hectare foram, aos 32 meses, de: $15,2585 \mathrm{~m}^{2} /$ ha para o espaçamento de $3,0 \times 1,0$ e de $8,8468 \mathrm{~m}^{2} /$ ha para o de $3,0 \times 2,0 \mathrm{~m}$.

Os coeficientes de variação foram ligeiramen te superiores para as progênies sob espaçamento de 3,0 x 2,0 $\mathrm{m}$, apresentando a tendência de aumentar conforme a idade, se do maiores os valores no espaçamento $3,0 \times 2,0$ do que no 3,0 $\mathrm{x} 1,0 \mathrm{~m}$, quando comparadas as mesmas idades.

As eficiências dos látices para essa característica foram sempre bem superiores a $120 \%$. A variação genë tica entre progênies foi semelhante nos dois espaçamentos, a julgar pulos valores do teste F obtidos nas anālises da vọriância.

A diferença entre o maior e o menor incremen to em área basal ao nível de médias de progênies, foi sempre mais expressiva para o espaçamento $3,0 \times 2,0 \mathrm{~m}$, evidenciando dessa forma a maior influência do espaçamento no crescimento 
em diâmetro e, consequentemente, na ărea basal das progênies. Na figura 5 , pode ser observada a evolução da área basal in dividual média das progênies, em função do espaçamento e da idade.

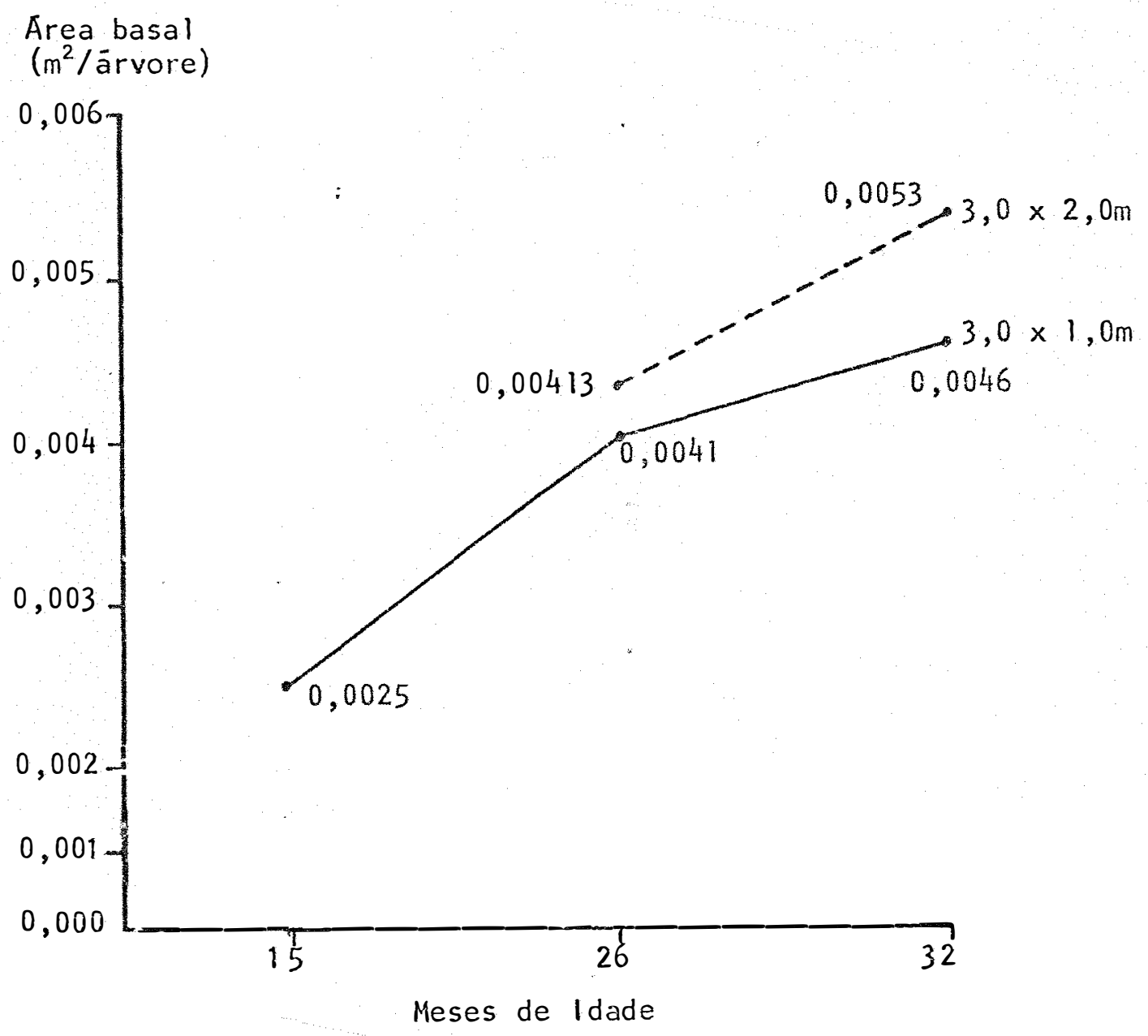

Figura 5 - Evolução do incremento em ârea basal individual média das pro gênies em função da idade e do espaçamento. 
A amplitude observada para o crescimento em âa rea basal das progênies aos 32 meses de idade, apresentou a mesma tendência verificada para o diâmetro, incrementando-se com a idade e com o espaçamento. Os valores das diferenças porcentuais entre as melhores e as piöres progênies foram mais expressivas no espaçamento mais amplo, atingindo aos 32 meses de idade, valores de 49,21\% e 64,00\% para os espaçamen tos de $3,0 \times 1,0$ e $3,0 \times 2,0 \mathrm{~m}$, respectivamente (tabela 7 ).

Os resultados obtidos mostram que a área basal individual média foi influenciada pelo espaçamento nas duas idades estudadas. A área basal média por hectare, produ to da área basal individual média pelo nümero de individuos por hectare, diminuiu com o aumento do espaçamento. E importante salientar que, mesmo que a área basal individual mëdia seja menor nos espaçamentos mais estreitos, em razão do núme ro maior de ärvores, a área basal média por hectare serâ maior que nos espaçamentos mais amplos. Os fatores que favorecem o crescimento em diâmetro tambēm favorecem o increnen to da ārea basal individual das árvores. Considerando o cita do anteriormente, o incremento da área basal por hectare vai depender do incremento da ārea basal individual média e do número de árvores do povoamento. 


\subsubsection{VOLUME CILINDRICO}

Os volumes individuais médios, obtidos para as progênies de Eucalyptus saligna Smith, nos espaçamentos e idades avaliados são apresentados na tabela 6. Esses valores, expressos como volume médio por hectare, foram calculados pa ra as idades de 15,26 e 32 meses, no espaçamento de $3,0 \mathrm{x}$ 1,0 , onde atingiram valores de $59,89 \mathrm{~m}^{3} / \mathrm{ha}, 135,42 \mathrm{~m}^{3} / \mathrm{ha}$ e $174,62 \mathrm{~m}^{3} / \mathrm{ha}$, respectivamente, e de $72,03 \mathrm{~m}^{3} / \mathrm{ha}$ e $99,72^{\circ} \mathrm{m}^{3} /$ ha para as idades de 26 e 32 meses, respectivamente, no espa çamento de $3,0 \times 2,0 \mathrm{~m}$.

Sendo o volume a característica mais importan te para avaliar a produtividade num povoamento florestal quan do se visa a produção de madeira, $\vec{\Xi}$ importante observar o comportamento das progênies face a esse caráter. O comporta mento do volume, quanto à amplitude observada entre as melho res e as piores progênies, mostrou que os maiores valores fo ram obtidos para o espaçamento de $3,0 \times 2,0 \mathrm{~m}$. Pode-se afirmar que o volume mêdio por hectare foi influenciado pelo es paçamentó já que ras três idades estudadas, as menores produ ções volumétricas corresponderam sempre ao espaçamento mais amplo .

Na figura 6, pode ser observada a evंolução. do volume cilindrico individual mëdio das progênies, em função do espaçamento e da idade. 


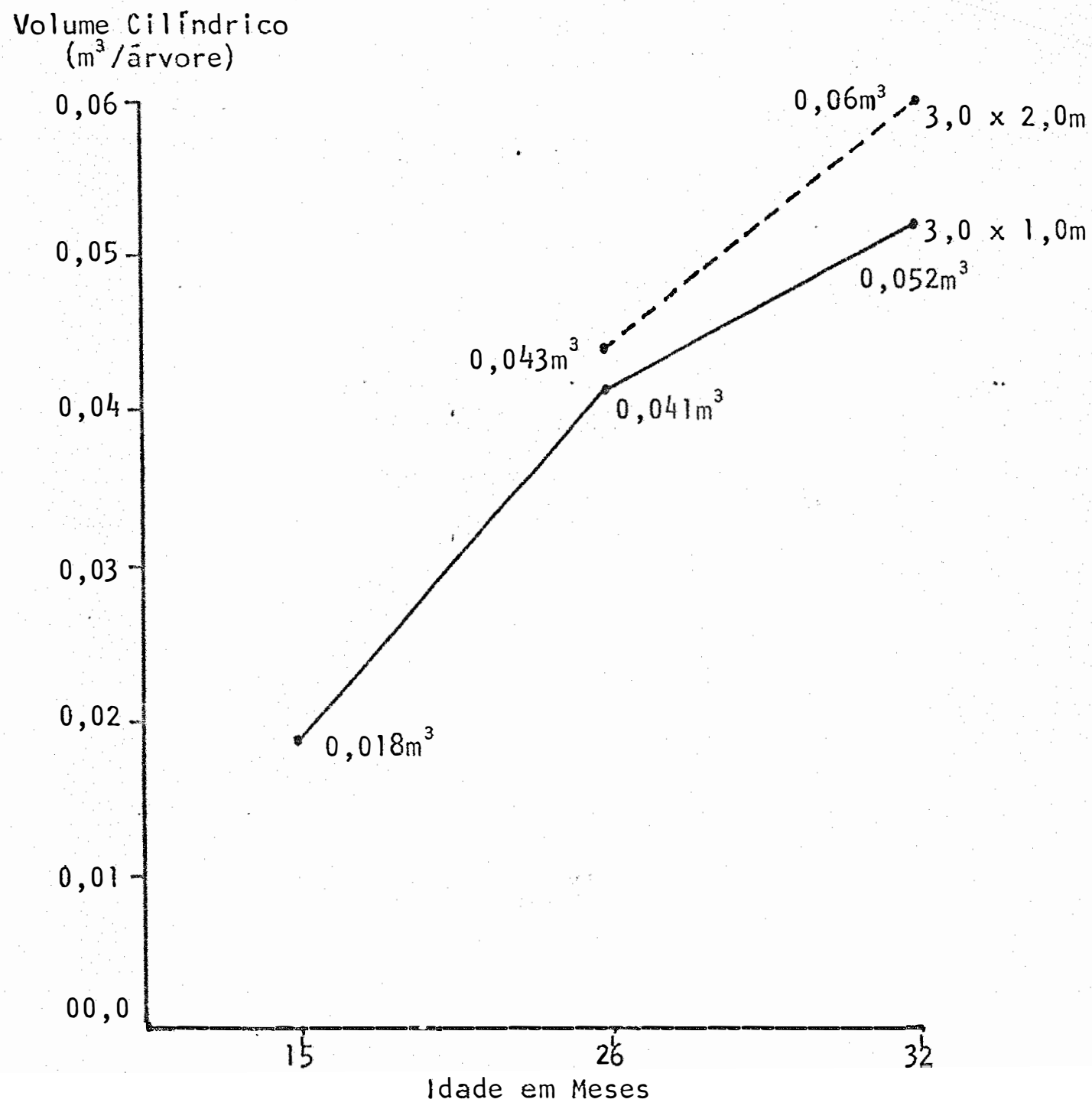

Figura 6 - Evolução em volume cilíndrico individual mểio das progênies em função da idade e do espaçannento. 
Considerando-se a amplitude da produção em vo lume e quando comparados os dois espaçamentos dentro de uma mesma idade, observou-se uma maior diferença no espaçamento mais amplo, alcançando, à idade de 32 meses, valores de 56,32\% e 73,01\% de diferença, nos espaçamentos de $3,0 \times 1,0$ e $3,0 \times$ 2,0 m, respectivamente. Esses dados, transformados para volu me cilindrico por hectare, representariam diferenças na produção em volume de 146,98 e $111,86 \mathrm{~m}^{3}$ de madeira, para os es paçamentos de $3,0 \times 1,0$ e $3,0 \times 2,0 \mathrm{~m}$, respectivamente, quan do utilizada a pior em vez da melhor progênie.

Os coeficientes de variação foram muito seme1hantes, porém apresentanđo uma tendência para aumentar em função da idade, dentro de um espaçamento, e em função do es paçamento a uma mesma idade. As eficiências do látice foram sempre superiores a $127 \%$, pelo qual se justificou plenamente a utilizaçäo desse delineamento experimental, segundo o afir mado por SNYDER (1966) e MIRANDA FILHO (1978).

Para o volume cilíndxico, a variação genética entre progênies foi bastante expressiva nos dois espaçamen tos e nas três idades avaliadas, o citado considerando os va lores de F obtidos nas análises da variância, tanto para o caso do látice (erro efetivo) quanto para o blocos ao acaso (erroblocos ao acaso).

Os resultados obtidcs confirmam aqueles repor tados por vários autores, dentre os quais salientam-se GUIMA RAES (1960), COUTO (1977), MESKIMEN E FRANKLIN (1978), BALLO 
NI e SIMOES (1980), que verificaram generalizadamente que em espaçamentos mais apertadoś e, consequentemente, com maior número de ärvores por hectare, o incremento em volume médio por hectare foi maior do que aquele produzido nos espaçamentos mais amplos.

\subsubsection{DENSIDADE BÁSICA DA MADEIRA}

Segundo HARRIS (1970) e ZOBEL e TALBERT (1984), o melhoramento das propriedades da madeira pode ser realiza. do atravês da manipulação genética e do manejo silvicultural dos povoamentos. As práticas culturais podem controlar o crescimento das árvores, como seria o caso do espaçamento, do desbaste e do melhoramento do "site", através da fertilização e do preparo do solo, que permitem manipular as taxas de crescimento e influenciar algumas propriedades da madeira, co mo a densidade básica e a percentagem de lenho tardío.

Considerando-se a importância de se conhecer a evolução do comportamento da densidade bâsica da madeira, nas progênies de Eucalyptus saligng. Smith, visando a sua uti lização para fins energéticos ou celulose, durante o desbaste efetuado à idade de 17 meses, foram colhidos de 5 a 6 dis cos de madeira de cada uma das 169 progênies dentro da repetição w do teste original no espaçamento $3,0 \times 1,0 \mathrm{~m}$.

os resultados, expressos ao nível de médias 
de parcelas, não foram analisados estatisticamente, devido a que a amostragem realizada não foi feita para todas as repetições do ensaio, sendo, portanto, considerados só ao nível de indices para essa caracteristica.

Na tabela 8 , a seguir, podem-se observar os valores da densidade bâsica e oś coeficientes de variação den tro de parcelas mëdio Cvd $\left(\begin{array}{l}0 \\ 0\end{array}\right)$ e o coeficiente de variação entre médias de progênies $\operatorname{CVp}\left(\frac{\%}{0}\right)$, obtidos para as 169 progênies sob estudo.

A média geral para esta característica foi de $0,411 \mathrm{~g} / \mathrm{cm}^{3}$, apresentando uma amplitude ao nível de médias de progênies, que variou de $0,363 \mathrm{~g} / \mathrm{cm}^{3}$ (progênie 01 ) atê um máa ximo de $0,454 \mathrm{~g} / \mathrm{cm}^{3}$ (progênie 128 ).

Ao nível de plantas individuais, as progênies mostraram uma amplitude maior, variando a densidade básica de $0,301 \mathrm{~g} / \mathrm{cm}^{3}$ para uma ärvore na progênie 01 até $0,564 \mathrm{~g} / \mathrm{Crin}^{3}$ pa ra uma ärvore na progênie 154 .

Os coeficientes de variação para ärvores dentro de parcelas mostraram valores variando de $1,52 \%$ até $13,39 \%$ a presentando um coeficiente de variação dentro médio de 4,02\%. Por outro Iado, as progênies apresentaram um coeficiente de variação entre suas médias de 4,24\%. Esses coeficientes de variação mostram que existe pouca variabilidade para a "densidade da madeira, tanto entre como dentro de progênies. No entanto, essa pouca variabilidade tem um forte controle genético, sen do característico para a densidade da madeira. 
.100 .

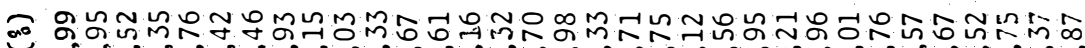

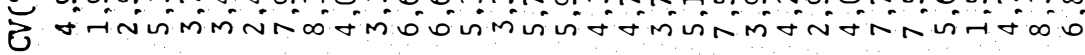

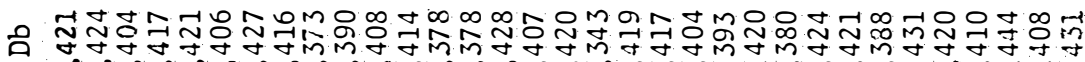

$00^{\circ} 0^{\circ} 0^{\circ} 0^{\circ} 0^{\circ} 0^{\circ} 0^{\circ} 0^{\circ} 0^{\circ} 0^{\circ} 0^{\circ} 0^{\circ} 0^{\circ} 0^{\circ} 0^{\circ} 0^{\circ} 0^{\circ} 0^{\circ} 0^{\circ}$

㞾

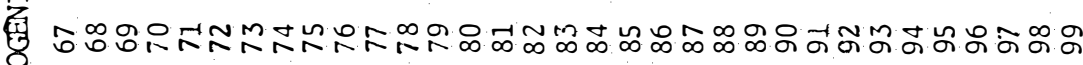
究

E

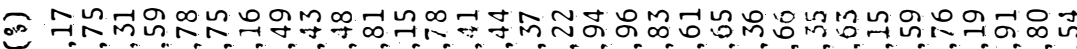

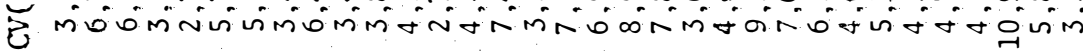

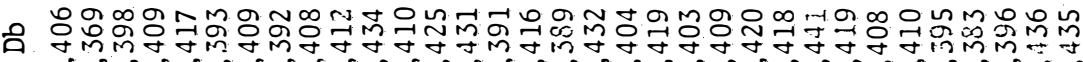

$00^{\circ} 0^{\circ} 0^{\circ} 0^{\circ} 0^{\circ} 0^{\circ} 0^{\circ} 0^{\circ} 0^{\circ} 0^{\circ} 0^{\circ} 0^{\circ} 0^{\circ} 0^{\circ} 0^{\circ} 0^{\circ} 0^{\circ} 0^{\circ} 0^{\circ} 0^{\circ} 0^{\circ}$

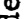

然

:

荘

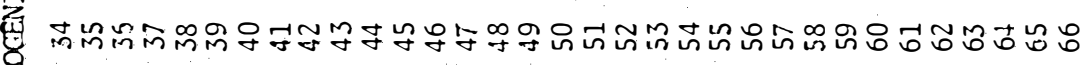

空

త్ర

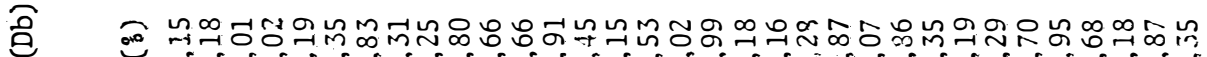

活

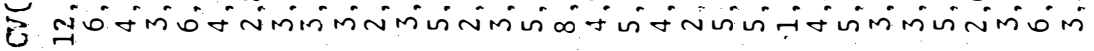

究

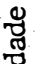

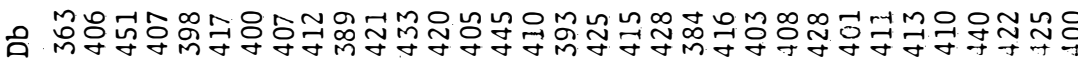

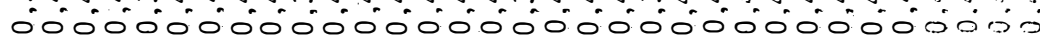
$\because$

$\mu$

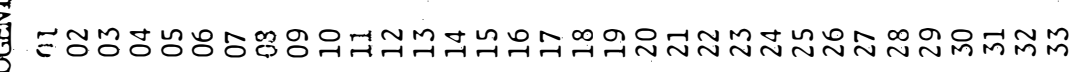


.101 .

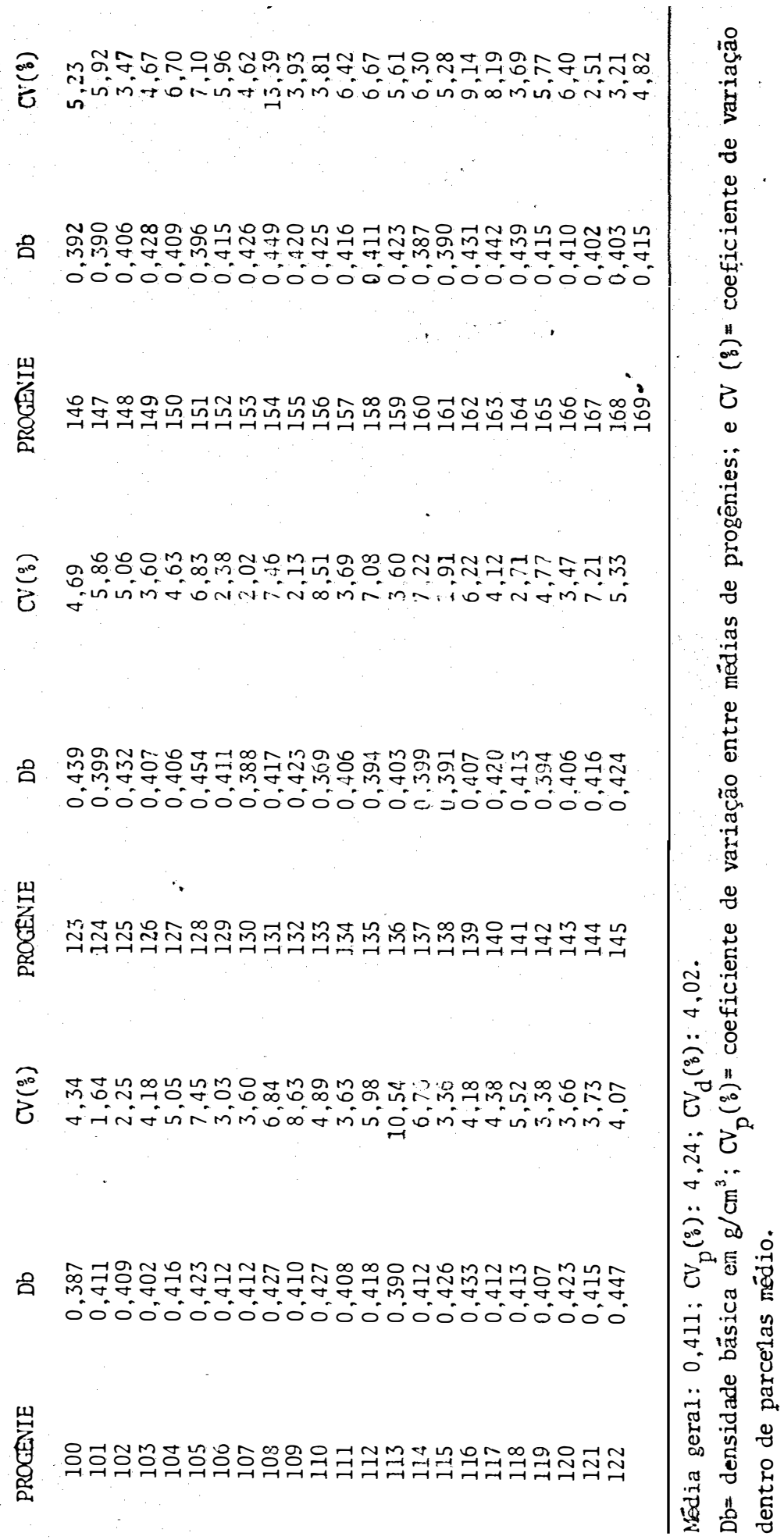


As variações detectadas para as progênies de Eucalyptus saligna Smith para os valores da densidade básica da madeira, são coerentes com os obtidos por outros autores para várias espécies de Eucalyptus. Assim, KAGEYAMA et alii (1982) obtiveram para E. grandis Hill ex Maiden valores mui to semelhantes de variação dentro e entre progênies estudadas em três locais diferentes. Por sua vez, CARPIM e BARRICHE LO (1983) encontraram variações consideráveis na densidade da madeira, ocorrendo tanto dentro das espécies como entre as espécies, e ainda dentro das árvores dessas espécies. As variações dentro das árvores foram verificadas por esses auto res como ocorrendo nos sentidos base - topo e medula - casca, e variando também com a idade do povoamento, com a procedên cia da semente e ainda com as progênies utilizadas.

Vários autores têm verificado a tendência pa ra as espécies de Eucalyptus de um aumento da densidade bás ca com a idade. FERREIRA (1972) e BARRICHELO et alii (1980), trabalhando com E. grandis Hill ex Maiden, observaram um aumento da densidade em função da idade do ta1hão. Por sua vez, FERREIRA e KAGEYAMA (1978) reportaram essa mesma variação da densidade bäsica com a idade, considerando quatro espécies de Eucalyptus, o que pode ser observado na tabela 9. 
Tabela 9 - Variação da densidade básica da madeira $\left(\mathrm{g} / \mathrm{cm}^{3}\right)$, em função da idade para quatro espécies de Eucalyptus.

\begin{tabular}{ccccc}
\hline $\begin{array}{r}\text { Idade } \\
\text { em anos }\end{array}$ & $\begin{array}{c}\text { E. urophylla } \\
\text { S T Blake }\end{array}$ & $\begin{array}{c}\text { E. grandis } \\
\text { Hili ex Maiden }\end{array}$ & $\begin{array}{c}\text { E. propinqua } \\
\text { Deane }\end{array}$ & $\begin{array}{c}\text { E. saligna } \\
\text { Smith }\end{array}$ \\
\hline 5 & 0,528 & 0,409 & 0,538 & 0,454 \\
7 & 0,572 & 0,462 & 0,580 & 0,482 \\
9 & 0,574 & 0,460 & 0,604 & 0,488 \\
11 & 0,603 & 0,474 & 0,623 & 0,586
\end{tabular}

Fonte: FERREIRA e KAGEYAMA (1978).

Quando são considerados os valores da densida de da madeira para algumas das árvores individuais, como aquela da progênie $154\left(0,564 \mathrm{~g} / \mathrm{cm}^{3}\right)$ do decorrente estudo, e comparados com aqueles obtidos pelos autores acima, percebese que algumas das progênies de Eucalyptus saligna Smith apresentaram, aos 17 meses de idade, valores muito próximos aos obtidos para a mesma espécie à idade de 11 anos. Por outro lado, quando comparados esses valores aos obtidos para as ov tras espécies estudadas, observa-se que as progênies de $E$. saligna Smith apresentaram valores maiores aos 17 meses de $\underline{i}$ dade, do que as quatro espécies aos 5 anos de idade, mostran do, assim, o grande potencial dessaj progênies para a produção de celulose ou de madeira para lenha.

Quando considerado o valor médio para a dens $\underline{i}$ dade básica da madeira para as progênies de Eucalyptus salig 
na Smith, obtido aos 17 meses de idade, percebe-se que esse valor é muito próximo do válor reportado por FERREIRA e KAGEYAMA (1978) para a mesma espécie à idade de 5 anos, muito embora para todas as comparações efetuadas, os locais de ensaio tenham sido diferentes.

KAGEYAMA et alii'(1982) detectaram para proge nies de Eucalyptus grandis Hill ex Maiden, testadas em três localidades, variações genéticas entre progênies para densidade da madeira ao nîvel de $1 \%$, e coeficientes de variação dentro médio e entre médias de progênies muito semelhantes aos obtidos no decorrente estudo para as progênies de E. saligne. Smith, aos 17 meses de idade. Aliās, as amplitudes apresenta das pelas progênies foram muito semelhantes nos dois casos considerados .

E importante salientar o fato de que, aincia que a variação da densidade básica da madeira apresentada pe las progênjes de Eucalyptus saligna Smith seja considerada baixa; os valores encontrados para essa população podem ser considerados como sendo significativos.

E importante ressaltar que, como não houve se leção para a densidade básica da madeira, pode-se considerar que a magnitude da variação detectada representa a variação que a população realmente contém.

KAGEYAMA et alii (1982) salientaram que a den sidade básica da madeira apresenta uma alta herdabilidade, fato que tem sido confirmado por numerosos autores para mui- 
tas espécies florestais. Esse fato sugere que a densidade bạ sica da madeira está sob fórte controle genético. A grande questão prática, continuam os autores, quando considerada a densidade básica, seria a de determinar com precisão o valor dessa característica para um número muito grande de indivíduos, sugerindo que a melhor estratégia de seleção seria aquela envolvendo a utilização de progênies em detrimento da seleção fenotípica.

Considerando-se o citado acima, percebe-se a importância de se analisar se, a tendência de algumás ārvores ou progênies de apresentar valores altos da densidade bâa sica continua ou se estabiliza com o decorrer da idade, o que representaria uma vantagem muito grande na definição da estratégia de seleção e melhoramento da característica.

\subsection{Resultados das Anälises d. V'ariância Individuais}

$\mathrm{Na}$ tabela 10 são apresentados os resultados das anâlises da variância individuais para as características estudadas, envolvendo a altura, o diâmetro e o yolume cí líndrico, nas três idades avaliadas e nos dois espaçamentos testados. Para a ārea basal, foram consideradas análises da variância para as idades de 26 e 32 meses, enquanto que para a sobrevivência das plantas e para forma das árvores só foi 
realizada uma análise à idade de 32 meses, envolvendo em ambos os casos os dois espaçamentos testados.

Variações genéticas significativas entre pro gênies foram detectadas para todas as características, em to das as idades e espaçamentos, sendo que os valores de F obti. dos nas análises da variância individuais foram altamentesig nificativos ao nível de 5\% em dois casos. Para as análises e fetuadas para sobrevivência, os valores de F foram não signi ficativos no espaçamento mais amplo, em ambos os delineamentos utilizados. Para a forma das árvores, no espaçamento 3,0 $x 1,0 \mathrm{~m}$ foi obtido um $\mathrm{F}$ não significativo.

Os valores de F, tanto para as anảlises da va riância em látice como para as de blocos ao acaso, não apre sentaram nenhuma tendência definida de variação com a idade ou com o espaçamento. No entanto, para as características de altura e diâmetro, foram observados valores quase sempremaio res no espaçamento mais amplo do que no $3,0 \times 1,0 \mathrm{~m}$, para am bos os deiineamentos utilizados. Somente para o caso do diâmetro, à idade de 32 meses, foi obtido maior valor de $F$ no espaçamento mais apertado e para o delineamento em iátice. Quando fnram consideradas as características compostas (área basal e volume cilíndrico), houve uma tendência inversa, obtendo-se valores maiores de $\mathrm{F}$ no espaçamento $3,0 \times 1,0 \mathrm{~m}$.

As variações genêticas, detectadas pelas análises da variância individuais, mostraram uma certa homoge neidade entre espaçamentos e entre idades dentro dos espaça- 
mentos, nos dois delineamentos considerados. As variäveis for ma das ärvores e altura de ṕlantas foram as que revelaram maiores valores de F para as progênies, vindo a seguir o diâa metro, a ārea basal, o volume e a sobrevivência.

Quando comparados os delineamentos em lätice e em blocos ao acaso, verificou-se uma tendência de valores maiores de F no delineamento em látice. Esse fato concorda com o salientado por DUDLEY e MOL (1969), sobre a maior sensibilidade do delineamento em látice para a comparação de mé dias. Para o caso da sobrevivência, os valores de F apresen taram-se iguais em ambos os delineamentos, para a idade considerada, sendo que esses valores foram mais expressivos no espaçamento mais apertado, podento ser um reflexo da maior mortalidade nesse espaçamento.

Os diferentes comportamentos das progênies nos dois espaçamentos avaliados podem ser interpretados como sen do uma expressão diferencial dos materiais genêticos de espa çamento fara espaçamento, o que pode refletir na interação de progênies $x$ espaçamentos. Esse compcrtamento pode ser explí cado tambẻm em função da variação do erro experimental entre os espaçamentos. 


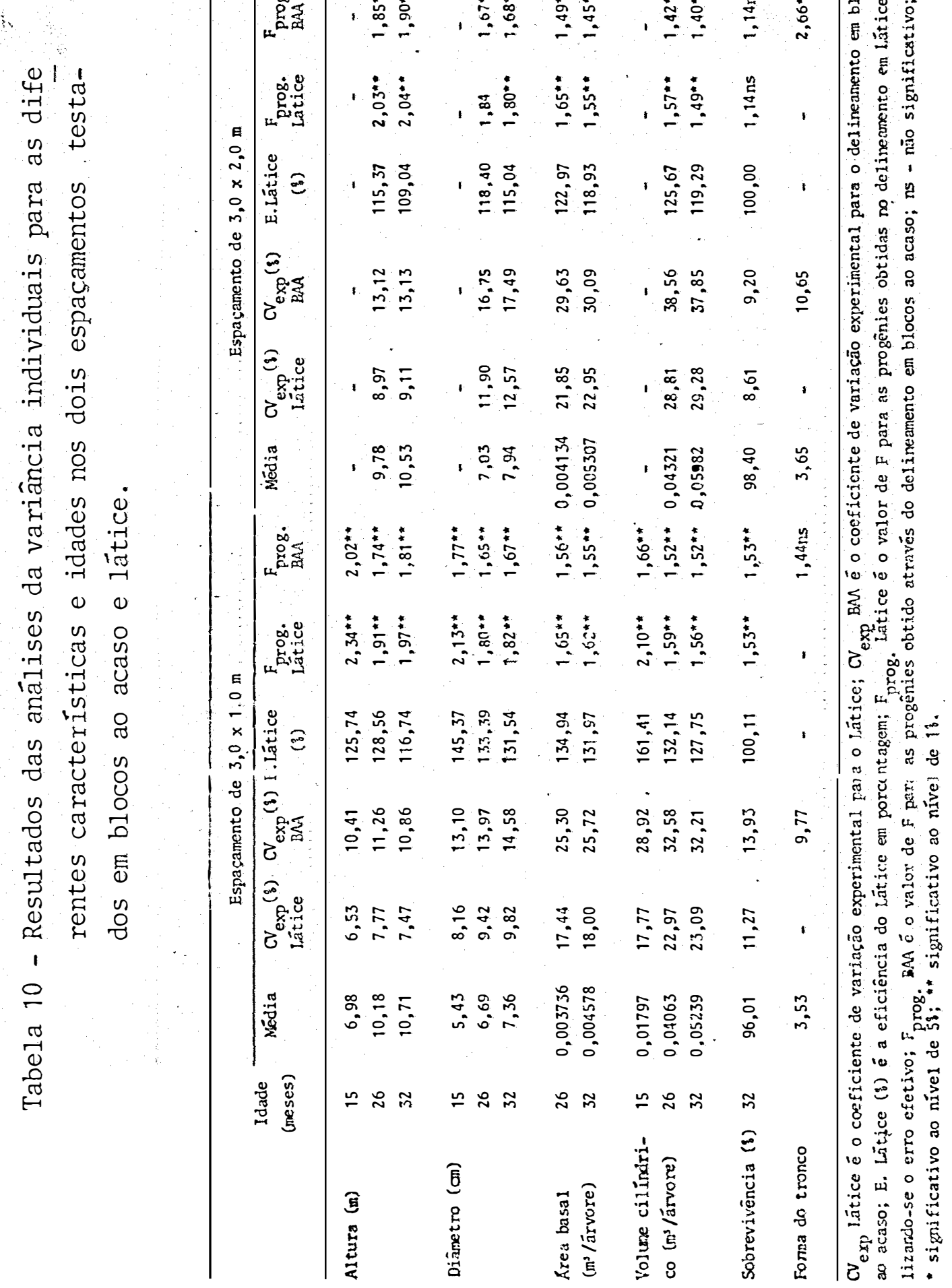


E importante salientar que, quando considera dos alguns dos trabalhos désenvolvidos na ärea florestal com espëcies de Eucalyptus ou Pinus, percebe-se que os coeficien tes de variação experimentais apresentam uma tendência dife rente daquela considerada por GOMES (1982) para culturas agrícolas, sobretudo quando são consideradas as característi cas compostas, comoárea basal e volume cilíndrico. Geralmente os valores dos coeficientes de variação nestes casos, sao maiores ficando na classificação de altos a muito altos, sen do que na realidade esses coeficientes, que contém a expressão de vảrias características, podem apresentar boas precisões. Os coeficientes de variação experimental ( $C V_{\text {exp }}$ ) para as características de crescimento e para sobrevivência das progênies e forma do tronco das ärvores, obtidos nas ana lises da variância individuais, em látice e em blocos ao aca so, apresentaram valores coerentes com outros estudos semelhantes, mostrando que para todas as características estuda das em ambos os espaçamentos, existiu uma boa eficiência estatistica:

Para a variāvel altura de plantas, os coeficientes de variação não apresentaram nenhuma tendência face ao espaçamento ou idade. Por outro lado, esses coeficientes apresentaian a tendência de aumentar em função da idade e do espaçamento, quando consideradas as características de diâme tro, ārea basal e volume cilíndrico.

As eficiências dos látices para as caracterís 
ticas de crescimento foram maiores do que $115 \%$ em todos os casos, exceto para altura de plantas no espaçamento $3,0 \times 2,0$ $m$, onde foi obtido um valor de 109\%; para sobrevivência, foram obtidas eficiências dos látices de $100 \%$ em ambos os espa çamentos.

Considerou-se, portanto, concordando com SNY DER (1966) e MIRANDA FILHO (1978), que esses valores das efi ciências dos látices justificaram plenamente a utilização do referido delineamento para a análise dos dados dos testes de progênies de Eucalyptus saligna Smith.

Os diferentes comportamentos dos tratamentos nos dois espaçamentos podem ser interpretados como uma expressão diferencial dos materiais genéticos de espaçamento para espaçamento, o que se refletiria na interação genótipo x espaçamento, ou podem também ser interpretados em função da variação do erro experi.... mental entre os dois espaçamentos.

Os coeficientes de variação experimental foram mais baixos e menos variáveis para altura de plantas, uss dois espaçanentos, e para o diâmetro no espaçamento de $3,0 \mathrm{x}$ $1,0 \mathrm{~m}$, sendo intermediārios para o diâmetro no espaçamento mais amplo e mais altos e variáveis para a área basal e volu me cilindrico. A altura e o diâmetro, que revelaram os valores mais baixos para os coeficientes de variação das anài ses da variância, mostraram, portanto, maior precisão exper $\underline{\underline{i}}$ mental. Esse fato indica que a forma em que foram avaliadas essas características apresentou uma boa eficiência experi- 
mental dentro de cada espaçamento ensaiado. Considerando a totalidade dos coeficientes de variação experimentais das análises da variância realizadas, pode-se afirmar que para to das as características estudadas existiu uma boa eficiência estatistica.

A avaliação da fơrma das ärvores foi feita à idade de 32 meses, envolvendo as 42 melhores progênies para volume cilíndrico no espaçamento $3,0 \times 2,0 \mathrm{~m}$. As progênies assim selecionadas foram avaliadas para forma das ârvores em ambos os espaçamentos, utilizando-se as notas definidas por KAGEYAMA (1980) para Eucalyptus grandis Hill ex Maiden:

Nota 1: Tronco com defeito muito grave; tronco muito tortuo so.

Nota 2: Tronco com defeito grave; tronco com tortuosidade a cima da média.

Nota 3: Tronco com defeito bastante visivel; tronco com tor tuosidade média.

Nota 4: Tronco com defeito pouco visível; tronco com tortuo sidade abaixo da média.

Nota 5: Tronco sem defeito; tronco tendendo à retidão ou to. 
As anâlises da variância individuais para for ma do tronco, nos dois espáçamentos testados, foram feitas para as 42 progênies de melhor produção em volume no espaçamento mais amplo, utilizando-se só o delineamento em blocos ao acaso.

Variações genétićas significativas ao nível de 1: foram detectadas para as progênies crescendo no espaçamento maior, a julgar pelo valor de F obtido. Para o espaça mento menor, não foi detectada variação genética significatí va.

As médias obtidas nas anảlises da variância, 3,53 para o espaçamento menor e 3,65 para o $3,0 \times 2,0 \mathrm{~m}$, sugerem que as progênies em ambos os espaçamentos apresentaram troncos que variaram, conforme a classificação definida por KAGEYAMA (1980), de troncos com tortuosidade média até troncos com defeitos pouco visíveis, sendo mais pröximos a esse ültimo conceito.

O teste Tukey, aplicado às 42 progênies ros dois espaçamentos, não revelou diferenças significativas entre as progênies, quando considerado o espaçamento menor. Por outro lado, quando considerado o espaçamento mais amplo, o teste Tukey mostrou diferenças significativas entre algumas das progênies, o que pode ser visualizado na tabela 11 , a se guir: 
Tabela 11 - Resumo das diferenças significativas entre médias de progê nies pelo teste Tukey para forma de tronco, no espaçamento $3,0 \times 2,0 \mathrm{~m}$.

\begin{tabular}{ccc}
\hline Progênie $n^{\circ}$ & $\begin{array}{c}\text { Teste Tukey } 1^{\circ} \\
\text { Progênies }^{* *}\end{array}$ \\
\hline 24 & 29400412280833 \\
10 & 0833 \\
09 & 0833 \\
38 & 33 \\
19 & 33 \\
05 & 33
\end{tabular}

** Progênies que diferem ao nível de $1 \%$ pelo teste Tukey das progênies relacionadas na primeira coluna.

E importante se considerar que as 42 progênies utilizadas para avaliar a forma das árvores foram as que apresentaram as melhores produções volumétricas dentro do es paçamentc maior, e que as mesmas foram avaliadas para forma das árvores em ambos os espaçamentos testados.

As progênies selecionadas dentro do espaçamen to $3,0 \times 2,0 \mathrm{~m}$, podem ser classificadas dentro daquelas quo apresentaram bom desenvolvimento no espaçamento maís amplo, assim como aquelas que se desenvolveram bem em ambos os espa çamentos.

A resposta das progênies para forma do tronco em função do espaçamento, apresentando melhor forma no espa- 
çamento mais amplo, sugere que as progênies de Eucalyptus sa ligna Smith apresentam características que se aproximam mais de espécies que reagem favoravelmente a espaçamentos abertos com maior luminosidade, ou seja, aquelas espécies consideradas como pioneiras na sucessão.

\subsection{Resultamos das Arálises da Variância Conjuntas Para as Caracteristicas de Crescimento e Forma do Tronco ENVOLVEndo os Espaçamentos Testados e as Idades Ava LIADAS}

Os resultados das anälises da variância conjuntas envolvendo os dois espaçamentos, para as característi cas de altura, diâmetro (dap), área basal e volume cilíndrico para as idades de 26 e 32 meses, são apresentados na tabe 1 a 12 . 
Tabela 12 - Resultados das análises da variância conjuntas para as carac terísticas de crescimento e forma do tronco, para os dois espaçamentos nas idades de 26 e 32 meses.

\begin{tabular}{|c|c|c|c|c|c|c|}
\hline $\begin{array}{l}\text { Caracte- } \\
\text { rística }\end{array}$ & $\begin{array}{l}\text { Idade } \\
\text { Meses }\end{array}$ & $\begin{array}{l}\text { Medias } \\
\text { Gerais }\end{array}$ & $\begin{array}{c}\mathrm{F} \\
\text { prog }\end{array}$ & $\begin{array}{l}\text { F } \\
\text { esp }\end{array}$ & $\begin{array}{l}F \text { prog } \\
x \text { esp. }\end{array}$ & $\begin{array}{c}\mathrm{CV} \exp \\
\left(\begin{array}{l}0 \\
0\end{array}\right)\end{array}$ \\
\hline \multirow[t]{2}{*}{ Altura (m) } & 26 & 9,98 & $3,16 * *$ & $2,51^{* *}$ & $0,80 \mathrm{~ns}$ & 14,88 \\
\hline & 32 & 10,62 & $3,30 * *$ & $0,42 \mathrm{~ns}$ & $0,72 \mathrm{~ns}$ & 15,10 \\
\hline \multirow[t]{2}{*}{ Diâmetro $(\mathrm{cm})$} & 26 & 6,86 & $2,72 * *$ & $2,98^{* *}$ & $0,93 \mathrm{~ns}$ & 17,81 \\
\hline & 32 & 7,65 & $2,77^{* *}$ & $7,85^{* *}$ & $0,85 \mathrm{~ns}$ & 18,97 \\
\hline \multirow{2}{*}{$\begin{array}{l}\text { Area basal } \\
\left(\mathrm{m}^{2} / \bar{a} \mathrm{rv}\right)\end{array}$} & 26 & 0,00394 & $2,39+*$ & $3,22 * *$ & $0,90 \mathrm{~ns}$ & 30,93 \\
\hline & 32 & 0,00494 & $2,33 * *$ & 8,59 ** & $0,8 \operatorname{lns}$ & 32,10 \\
\hline \multirow{2}{*}{$\begin{array}{l}\text { Vol. Cilíndrico } \\
\left(\mathrm{m}^{3} / \overline{\mathrm{a}} \mathrm{rv}\right)\end{array}$} & 26 & 0,0419 & $2,38 * *$ & $0,63 \mathrm{~ns}$ & $0,78 \mathrm{~ns}$ & 40,47 \\
\hline & 32 & 0,0561 & $2,29 * *$ & $3,39 * *$ & $0,75 \mathrm{~ns}$ & 40,58 \\
\hline $\begin{array}{l}\text { Forma das ärrores } \\
\text { (notas) }\end{array}$ & s 32 & 3,59 & $3,55^{* *}$ & $2,77^{* *}$ & $0,77 \mathrm{~ns}$ & 10,22 \\
\hline
\end{tabular}

$\mathrm{F}$ prog $=\mathrm{F}$ progênies; $\mathrm{F}$ esp $=\mathrm{F}$ espaçanentos; $\mathrm{F}$ prog $\mathrm{x}$ esp $=\mathrm{F}$ progênies $\mathrm{x}$ espaçamentos; CV $\exp =$ coeficienite de variação experimental ; ** significiativo ao nível de $1 \%$; ns = não significativo; área basal em $\mathrm{m}^{2}$ por árvore; vol. çilíndrico $=$ volume cilíndrico $\left(\mathrm{m}^{3}\right.$ por ärvore) .

As características de crescimento (altura, diâa metro, ārea basal e volume cilíndrico) e a forma dảs árvores apresentaram variações genéticas significativas ao nível de $1 \%$, que foram detectadas pelos respectivos valores de F obti dos das análises da variância conjuntas nos dois espaçamentos testados. 
Os resultados obtidos apresentaram valores de F muito semelhantes, tanto para as características estudadas como para as idades de 26 e 32 meses consideradas. Esses valores não apresentaram nenhuma tendência de incremento ou di minuição com a idade das progênies, embora as característi cas simples (altura e diâmetro) tenham aumentado ligeiramente com a idade; as características compostas (área basal e volume cilíndrico) apresentaram ligeiras diminuições dos valores de F com o aumento da idade.

Os coeficientes de variação experimental

exp) aumentaram com a idade, apresentando a mesma tendência observada para as anảlises individuais, revelando maiores va lores para as características compostas (ärea basal e volume cilindrico) comparativamente à altura e diâmetro.

As caracteristicas de altura e diâmetro, que foram avaliadas ao nível de médias de parcelas por planta, a presentaram erros experimentais considerados, segundo GONES (1982), como sendo médios para ensaios de campo, mostranro boas precisões para as anảlises estatísticas para essas características. As variáveis compostas, ärea basal e volume cí líndrico, apresentaram uma tendência de maior erro experimen tal, tanto quando comparadas entre si, como entre as idades consideradas.

COCHRAN e COX (1965) mostram que, para as an $\underline{\underline{a}}$ lises da variância conjuntas, deve-se considerar que o mode10 estabelecido seja cumprido e que os erros experimentais 
das observações individuais apresentem uma distribuição nor mal e independente. Deve háver também homogeneidade para a variância da variação do erro $\left(\sigma_{\mathrm{e}}^{2}\right)$ e as médias da população precisam ter a mesma variância das médias das características $\left(\sigma_{\mathrm{m}}^{2}\right)$, que devem ser independentes, por sua vez, dos erros.

Os efeitos dos espaçamentos sobre o crescimen to das progênies foram expressivos, com significâncias ao ní vel de $1 \%$ para o diâmetro e a ärea basal, nas duas idades consideradas. A variação entre progênies face ao espaçamento foi maior à idade de 32 meses, a julgar pelos valores de F ob tidos, para essas mesmas características.

Por outro lado, para a variável altura das plantas, os valores de $F$ para os efeitos do espaçamento apre sentaram-su como sendo significativos ao nível de $1 \%$ à idade de 26 meses e como não significativo para a idade de 32 meses.

Esse fato poderā ser explicado considerandose o comportamento das progênies, no que a crescimento em a tura se refere, em cada um dos espaçamentos envolvidos, dos 26 para ns 32 meses de idade. Nesse período a diferença em altura entre as progênies, crescendo nos dois espaçamentos, se viu diminuida, apresentando-se quase que o mesmo valor em ambos os espaçamentos à idade de 32 meses. Esses fatos sugerem, portanto, que a variância entre progênies foi afetada pelos espaçamentos, o que concordaria com o salientado por 
MATHESON E RAYMOND (1984a).

0 crescimento em volume apresentou uma situa ção inversa à altura, obtendo-se valores de F não significa tivos ao nível de 1 : na de 32 meses. A idade de 26 meses, as médias para os dois espaçamentos $\left(0,02094 \mathrm{~m}^{3} /\right.$ árvore para o espaçamento menor, e $0,02017 \mathrm{~m}^{3} /$ árvore para o de $3,0 \times 2,0 \mathrm{~m}$ ) apresentaram valores muito próximos, ocorrendo, em consequên cia, o mesmo fato citado para o caso da altura, mostrandoque nessa idade, 26 meses, o espaçamento não influiu na produção volumétrica das progênies. O valor de F, obtido para a idade de 32 meses, sugere que, nessa idade, a produção volumétrica das progênies já começa a ser influenciada pelos efeitos dos espaçamentos.

Pode-se considerar que as variações entre os doi.s espaçamentos, para o crescimento das progênies, não fcram devidas a diferenças climáticas, pelo fato de que ambos os ensaios contendo os espaçamentos testados se encontravam crescendo no mesmo local.

0 mesmo pode ser comentado sobre as diferenças edáficas, ainda que nesse cáso, poderiam ocorrer varia ções microambientais nas parcelas, afetando a expressão das progênies. Embora acredite-se que a extrema proximidade das parcelas nos dois espaçamentos testados e a existência de quatro repetições no ensaio, tenha contribuído para diminuii esse efeito à sua mínima expressão. Considerando-se, então, que essas diferenças em crescimento das progênies são devi- 
das aos efeitos diferenciais da expressão genética entre progênies em função dos espaçamentos considerados.

A interação progênies $x$ espaçamento mostrou va lores de F bem pouco expressivos para todas as caracteristicas e idades avaliadas, com todos os valores de F encontrados como não significativos e menores do que 1. Esse fato sugere que a variância da interação nessas idades apresentou um valor próximo de zero, ou aináa que esse valor da interação con tém algum pequeno efeito não controlado na experimentação, não sendo possível o seu isolamento.

COCHRAN e COX (1:965) mostram que alguns componentes das somas dos quadrados da interação podem ser maiores do que os outros, ou seja, que a variância da interação não seja constante. Esse fato acontece quando o efeito dos espaçamentos varia muito em sua ação sobre algumas das progênie:: enquanto que para outras progênies esse efeito é menor ou ainda pode ilão acontecer.

Considerando-se a possibilidade de que a falta de expressão dos valores de F para a interação genótipo x espaçamento foi devida ao fato das progênies apresentarem interações as nível das diferentes repetições dos ensaios e que essas interações entre repetições poderão disfarçar as intera ções genótipo x espaçamento existentes, foram efetuadas anälí ses da variância em látice e em blocos ao acaso para a característica de volume cilíndrico. Os dados para os tratamentos consistiram das diferenças encontradas entre o volume no espa 
çamento de $3,0 \times 2,0 \mathrm{~m}$, e do volume do espaçamento mais apertado, para cada uma das prógênies sob estudo e para cada uma das respectivas repetições do ensaio. Para essas diferenças foi respeito o sinal obtido. Os resultados obtidos podem ser visualizados ṇa Tabela 13 a seguir:

Tabela 13 - Resultados das anâlises da variância das diferenças na produção volumétrica entre as progênies nos dois espaçamentos testados.

Média geral $\ldots \ldots \ldots \ldots \ldots \ldots \ldots \ldots \ldots \ldots, 0,00743$

Eficiência do lătice ............... $100,02_{0}^{\circ}$

Coeficiente de variação experim. .......... 234,24\%

F progênjes lätice ................. 1,07ns

F progenenies blocos ao acaso $\ldots \ldots \ldots \ldots \ldots, 1,07 \mathrm{~ns}$

ns $=$ não significativo .

A anälise da variância apresentoli valores de $F$ não significativos nos dois delineamentos utilizados, sendo que esses valores for am da mesma magnitude em ambos os delineamentos .

o coeficiente de variação experimental obtido apresentou-se como sendo excessivamente aito $(234,24 \%)$, o que mostra a mu dança de comportamento das diferenças entre os espaçamentos para as progê nies nas diferentes rep̣etições. 
Considerando-se que só a partir de anâlises maj.s detalhados é que poderia-sé detectar com maior precisão a existência da interação genötipo $x$ espaçamento, procedeu-se ao desdobramento das anảlises da variância conjuntas para as características de crescimento, envolvendo os espaçamentos testados, para a idade de 32 meses: Os resultados obtidos podem ser observados na Tabela 14.

Tabela 14 - Resultados do desdobramento dos efeitos das progênies dentro dos espaçamentos avaliados.

Características Altura Diânetro Area basal cilíndrico

Progênies/espaçamentos
$(3,0 \times 1,0 \mathrm{~m})$
$1,62 * *$
$2,24^{* *}$
$1,98 * *$
$1,00 \mathrm{~ns}$

Progênies/espaçamentos
$(3,0 \times 2,0 \mathrm{~m})$
$2,40^{* *}$
$4,22 *$
$4,14^{* *}$
$2,02 * *$

** significativo ao nível de 1\%; ns - não significativo.

Os resultados obtidos mostram que quando cons $\underline{i}$ deradas as progênies dentro dos espaçamentos, tanto o 3,0 $\mathrm{x}$ I,0 m ccmo no $3,0 \times 2,0 \mathrm{~m}$, os valores de $\mathrm{F}$, obtidos atra vés da relação do seu quadrado médio com o erro médio utiliza do nas anălises da variância conjuntas, mostraram-se significativos ao nível de $1 \%$ em todos os casos, exceto para o volu- 
me cilindrico para progênies dentro do espaçamento $3,0 \times 1,0 \mathrm{~m}$ onde esse valor foi não siğnificativo.

A tendência dos valores de F assim obtidos foi apresentar sempre, para todas as características avaliadas, va lores maiores para o caso das progênies dentro do espaçamen to de $3,0 \times 2,0 \mathrm{~m}$; mostrando assim a maior expressividade das progênies dentro do espaçamento mais amplo.

Quando analisados os valores de F para as características avaliadas, percebe-se que o diâmetro e a área basal apresentaram uma maior expressão do que a altura e o vo lume cilindrico. A variação entre progênies dentro do espaça mento $3,0 \times 1,0$ foi menor do que para o espaçamento mais amplo, se bem que a diferença entre o diâmetro e a área basal não tenha sido tão gxande como para o caso de $3,0 \times 2,0 \mathrm{~m}$. Em bora, tenham sido obtidos valores com significância ao nivel de 1\% para altura; diâmetro e área basal, o volume cilíndrico foi a característica que apreseniou o menor valor de $F$ e o $\vec{i}$ nico que foi não significativo ao espaçamento $3,0 \times 1,0 \mathrm{~m}$.

Considerando-se que o volume, característica composta pela altura e o diâmetro, reflete mais o efeito das progênies dentro dos espaçamentos, pode-se afirmar que as pro gênies reagiram diferentemente nos espaçamentos 3,0 x $1,0 \mathrm{~m}$ e 3,0 $\times 2,0 \mathrm{~m}$, o que caracterizaria uma interação de tipo simples.

Quando comparadas as médias ajustadds das características de crescimento das progênies, nos espaçamentos de $3,0 \times 1,0$ e $3,0 \times 2,0 \mathrm{~m}$ e colocadas em função da posição 
relativa que ocuparam em cada um dos espaçamentos, perceber:-se o comportamento diferencial das progênies face aos dois espaçamentos.

E importante salientar que as melhores progênies, para as características estudadas, não foram as mesmas nos dois espaçamentos, porém, existindo algumas progênies que reagiram de forma similar nos dois espaçamentos, ocupando qua se que a mesma posição.

Considerando-se as médias de tratámentcs ajustadas, para as diferentes características estudadas, a respos ta das progênies nos dois espaçamentos testados permitiu dife renciar três tipos de comportamento das progênies face ao espaçamento:

(a) Progênies que se desenvolveram melhor no espaçamento mais apertado $(3,0 \times 1,0 \mathrm{~m})$;

(b) Progênies que se desenvolveram igualmente em ambos os espaçamentiss, ocupando tanto as melhores quanto as pinres posiçõəs, ou ainda posições intermediärias, em ambos os espaçamentos; e

(c) Progênies que se desenvolveram melhor no espaçamento mais amplo $(3,0 \times 2,0 \mathrm{~m})$.

Isso pode ser melhor verificado ao se observar a Figura 7, onde foram colocadas as médias dos volumes cilíndricos individuais médios de algurras das progênies estudadas 
face ao espaçamento.

Nas Tabelas" 15 e 16 podem ser observados os vo lumes apresentados pelas progênies para os dois espaçamentos estudados e as posições que ocuparam as progênies quando cres cendo nos espaçamentos de $3,0 \times 1,0 \mathrm{~m}$ e $3,0 \times 2,0 \mathrm{~m}$, respectí vamente.

Quando observada a Figura 7 pode-se verificar a existência de um maior número de progênies que se sobressaí ram no espaçamento de $3,0 \times 2,0 \mathrm{~m}$ do que no de $3,0 \times 1,0 \mathrm{~m}$. Es se fato pode ser explicado considerando-se que o Eucalyptus saligna Sinith é intolerante à competição, reagindo em consequência mais favoravelmente ao maior espaço disponível. Hillis e Brown (1978) citados por BALLONI e SIMOES (1980) e GUIMARAES (1960 e 1965), salientaram o fato de E. saligna Smith é uma espécie intolerante à competịção.

Esse melhor comportamento das progênies no espaçamento maior também pode ser explicado considerando o reı̃a tado por KAGEYAMA (1986), sobre a existência nas espécies florestais de uma tendência para a classificação das espécies em função a sua resposta a maior ou menor quantidade de luz, salientand que essas respostas podem ser explicadas pelas exigências diferenciais de luz das plantas no decorrer da sucessão. No caso dos eucaliptos, apresentaram-se, segundo o autor, teriencias semelhantes mostrando efeitos diferenciais entre espécies face ao espaçamento, revelando que as espécies de Eucalıptus não são homogêneas quanto a esse aspecto. 


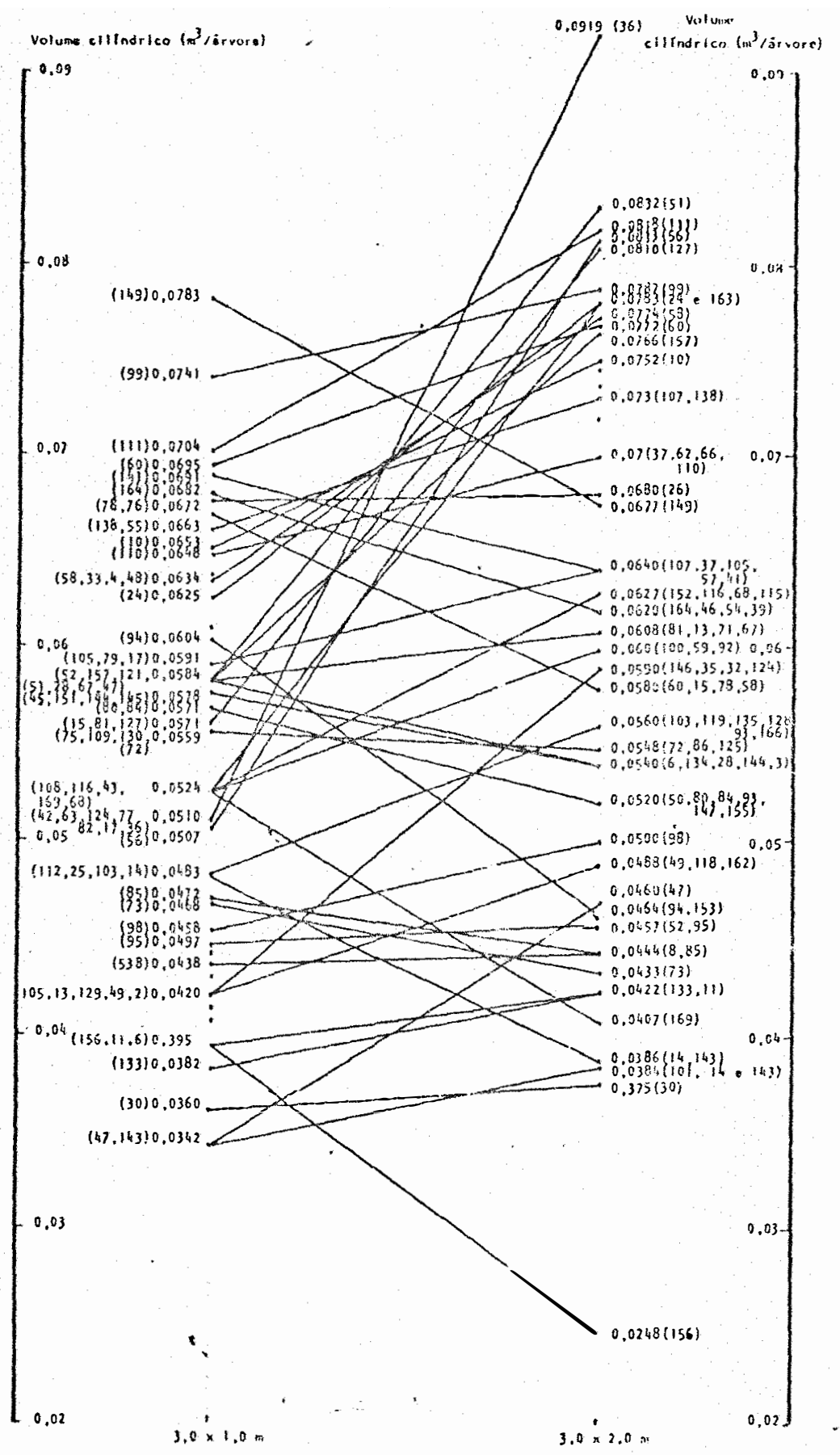

(x) Idesillficaçào dos progennles: 0,0500 valor do volune ell'adrico indivilual médlo para as progôntes. locallizudas nesse ponco.

Figura 7 - Comportanento de algumas das pıogênies de Eucalyptus saligna Smith, na produção em volune cilíndrico ( $\mathrm{m}^{3} /$ ärvore), nos dois espaçamentos testados à idade de 32 meses. 
Tabela 15 - Mêiias ajustadas e ordenadas das progênies de Eucalyptus saligna Smith para volume cilindrico ( $\mathrm{m}^{3} /$ ărvore) à idade de 32 meses e para o espaçamento de $3,0 \times 1,0 \mathrm{~m}$, mostrando a posi ção relativa das progênies nos dois espaçamentos.

\begin{tabular}{|c|c|c|c|c|c|c|c|}
\hline $\begin{array}{c}\text { rosigäio em } \\
3,0 \times 1,0\end{array}$ & $\begin{array}{c}\text { Progsinie } \\
\left(n^{0}\right)\end{array}$ & $\begin{array}{l}\text { Posisjo com } \\
3.0 \times 3.0\end{array}$ & $\begin{array}{l}\text { Voluse } \mathrm{cm} \\
3,0 \times 1,0\end{array}$ & 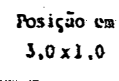 & $\begin{array}{l}\text { Proyinic } \\
\left(n^{\circ}\right)\end{array}$ & $\begin{array}{l}\text { Iusiisa cm } \\
3,0 \times 2,0\end{array}$ & $\begin{array}{l}\text { Volitine ca } \\
3,0 \times 1,0\end{array}$ \\
\hline $\begin{array}{l}1 \\
2 \\
3 \\
3 \\
3 \\
3 \\
6 \\
7 \\
3 \\
10 \\
11 \\
12 \\
13 \\
14 \\
15 \\
15 \\
17 \\
18 \\
19 \\
20 \\
21 \\
22 \\
23 \\
24 \\
25 \\
26 \\
27 \\
28 \\
29 \\
39 \\
31 \\
32 \\
33 \\
34 \\
35 \\
36 \\
37 \\
38 \\
39 \\
46 \\
41 \\
42 \\
43 \\
44 \\
45 \\
46 \\
17 \\
18 \\
49 \\
42 \\
51 \\
52 \\
53 \\
54 \\
55 \\
56 \\
57 \\
58 \\
59 \\
60 \\
61 \\
62 \\
63 \\
64 \\
65 \\
65 \\
65 \\
68 \\
68 \\
69 \\
70 \\
71 \\
72 \\
73 \\
74 \\
75 \\
76 \\
77 \\
72 \\
79 \\
80 \\
81 \\
82 \\
83 \\
84 \\
85\end{array}$ & 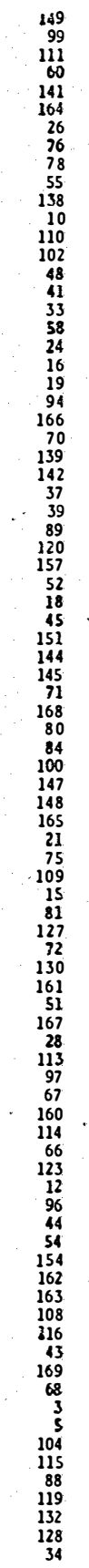 & $\begin{array}{c}43 \\
43 \\
07 \\
03 \\
11 \\
50 \\
70 \\
70 \\
41 \\
25 \\
91 \\
06 \\
20 \\
13 \\
31 \\
31 \\
44 \\
21 \\
111 \\
27 \\
10 \\
08 \\
54 \\
109 \\
156 \\
105 \\
79 \\
17 \\
51 \\
28 \\
67 \\
47 \\
121 \\
12 \\
158 \\
14 \\
96 \\
22 \\
117 \\
60 \\
73 \\
35 \\
131 \\
132 \\
78 \\
129 \\
15 \\
151 \\
49 \\
26 \\
17 \\
90 \\
13 \\
5 \\
5 \\
115 \\
75 \\
36 \\
40 \\
40 \\
119 \\
16 \\
133 \\
74 \\
89 \\
103 \\
30 \\
46 \\
15 \\
38 \\
140 \\
68 \\
146 \\
144 \\
9 \\
58 \\
65 \\
153 \\
164 \\
64 \\
116 \\
57 \\
113 \\
63 \\
125 \\
123 \\
123 \\
107 \\
87\end{array}$ & 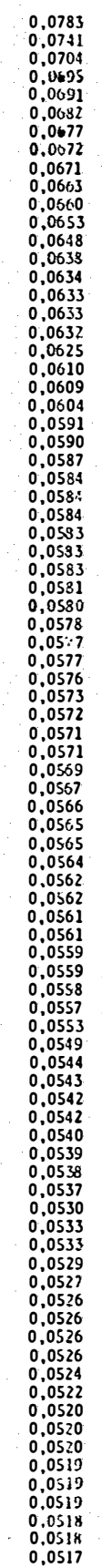 & $\begin{array}{l}86 \\
87 \\
88 \\
89 \\
90 \\
91 \\
92 \\
92 \\
93 \\
94 \\
95 \\
95 \\
97 \\
97 \\
98 \\
99 \\
100 \\
101 \\
102 \\
103 \\
104 \\
105 \\
106 \\
107 \\
108 \\
110 \\
111 \\
112 \\
113 \\
114 \\
115 \\
116 \\
117 \\
118 \\
119 \\
120 \\
121 \\
125 \\
124 \\
125 \\
126 \\
127 \\
128 \\
129 \\
130 \\
131 \\
132 \\
135 \\
134 \\
135 \\
136 \\
157 \\
138 \\
139 \\
145 \\
141 \\
142 \\
143 \\
144 \\
145 \\
146 \\
147 \\
148 \\
149 \\
150 \\
151 \\
152 \\
153 \\
154 \\
155 \\
156 \\
157 \\
158 \\
159 \\
160 \\
161 \\
162 \\
163 \\
164 \\
165 \\
166 \\
167 \\
168 \\
169 \\
\end{array}$ & 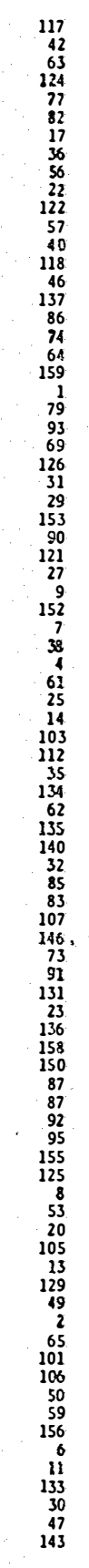 & 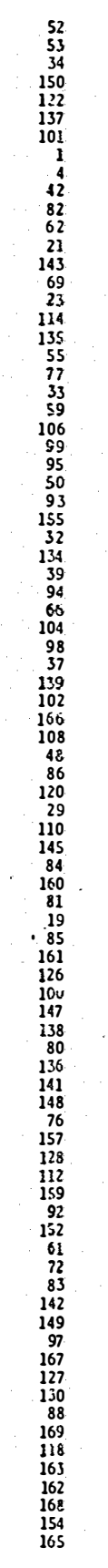 & 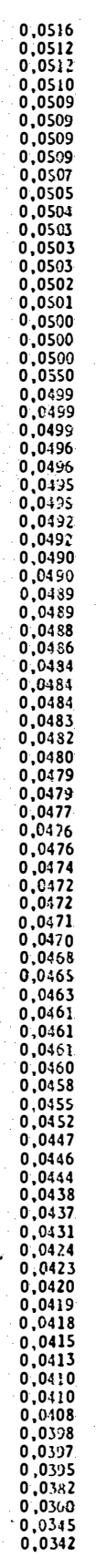 \\
\hline
\end{tabular}


Tabela 16 - Médias ajustadas e ordenadas das progênies de Eucalyptus saligna Smith para volúme cilindrico ( $\mathrm{m}^{3} /$ ärvore) à idade de 32 meses no espaçamento de $3,0 \times 2,0 \mathrm{~m}$, mostrando a posição rela tiva das progênies nos dois espaçamentos.

\begin{tabular}{|c|c|c|c|c|c|c|c|}
\hline $\begin{array}{l}\text { Posigio cia } \\
3.0 \times 2.0\end{array}$ & $\begin{array}{l}\text { iruginis } \\
\text { (nin) }\end{array}$ & $\begin{array}{l}\text { Posivio ent } \\
3,0 \times 1,0\end{array}$ & $\begin{array}{l}\text { Voluax } \leq m \\
3,0 \times 2=0\end{array}$ & $\begin{array}{l}\text { Pusisio } \\
3,0 \times 2,0\end{array}$ & $\begin{array}{l}\text { Progsinie } \\
\left(n^{\circ}\right)\end{array}$ & $\begin{array}{l}\text { Posicju cu } \\
3.4 \times 1.0\end{array}$ & $\begin{array}{l}\text { Voluxe con } \\
3.0 \times 2,0\end{array}$ \\
\hline 1 & 36 & 93 & 0,0919 & 80 & 35 & & 0,050 \\
\hline$\frac{2}{3}$ & 51 & 55 & $0.0 \times 32$ & 87 & 34 & 85 & $\begin{array}{l}0.0 .059 \\
0.05 \% 4\end{array}$ \\
\hline 4 & $\begin{array}{c}111 \\
56\end{array}$ & $\begin{array}{l}03 \\
94\end{array}$ & 0,0818 & $\begin{array}{l}88 \\
89\end{array}$ & 59 & 102 & 0.0550 \\
\hline${ }_{6}^{5}$ & 227 & 51 & $\begin{array}{l}0.08510 \\
0.081\end{array}$ & $\begin{array}{l}89 \\
90\end{array}$ & $\begin{array}{l}160 \\
15\end{array}$ & $\begin{array}{l}61 \\
49\end{array}$ & $\begin{array}{l}0.0550 \\
0.0555\end{array}$ \\
\hline 9 & $\begin{array}{l}55 \\
99\end{array}$ & $\begin{array}{l}10 . \\
02\end{array}$ & $\begin{array}{l}0.0805 \\
0.0787\end{array}$ & .91 & 78 & 9 & $\begin{array}{l}0.00575 \\
0.0574\end{array}$ \\
\hline 8 & 24 & 19 & $\begin{array}{l}0.0787 \\
0.0733\end{array}$ & $\begin{array}{l}92 \\
93\end{array}$ & $\begin{array}{l}53 \\
29\end{array}$ & 151 & 0.0574 \\
\hline 10 & $\begin{array}{l}163 \\
58\end{array}$ & 71 & 0.0733 & 94 & 9 & $\begin{array}{l}112 \\
117\end{array}$ & 0.0574 \\
\hline $\begin{array}{l}10 \\
11\end{array}$ & $\begin{array}{l}58 \\
60\end{array}$ & 19 & 0.0774 & 95 & 126 & 110 & $\begin{array}{l}0.0753 \\
0.0572\end{array}$ \\
\hline$\frac{11}{12}$ & $\begin{array}{l}60 \\
157\end{array}$ & $\begin{array}{l}04 \\
31\end{array}$ & $\begin{array}{l}0,0772 \\
0.0766\end{array}$ & 96 & 45 & 34 & 0.0509 \\
\hline 13 & 10 & 12 & $\begin{array}{l}0.0766 \\
0.0752\end{array}$ & 97. & 65 & 158 & 0.0569 \\
\hline $\begin{array}{l}14 \\
15\end{array}$ & 18 & 33 & 0.0743 & 99 & $\begin{array}{l}56 \\
69\end{array}$ & $\begin{array}{l}120 \\
109\end{array}$ & $\begin{array}{l}0.0507 \\
0.0556\end{array}$ \\
\hline $\begin{array}{l}15 \\
16\end{array}$ & ${ }_{143}^{148}$ & $\begin{array}{l}44 \\
58\end{array}$ & 0.0748 & 100 & 131 & 139 & 0.0556 \\
\hline $\begin{array}{l}16 \\
27\end{array}$ & $\begin{array}{l}113 \\
109\end{array}$ & $\begin{array}{l}38 \\
48\end{array}$ & 0.0748 & 101 & 17 & 92 & 0.0555 \\
\hline 18 & $\begin{array}{l}1139 \\
139\end{array}$ & $\begin{array}{l}48 \\
25\end{array}$ & $\begin{array}{l}0.0746 \\
0.0738\end{array}$ & 3 & 25 & 323 & 0.0565 \\
\hline 29 & $\begin{array}{l}107 \\
10\end{array}$ & $\begin{array}{l}13 \\
135\end{array}$ & $\begin{array}{l}0.0738 \\
0.731\end{array}$ & 107 & 114 & 62 & 0.0562 \\
\hline 20 & $\begin{array}{l}138 \\
138\end{array}$ & 11 & 0.0726 & $\begin{array}{l}157 \\
105\end{array}$ & $\begin{array}{r}7 \\
166\end{array}$ & 119 & $0.05 \mathrm{~s} 2$ \\
\hline 21 & 40 & 98 & 0.0726 & $\begin{array}{l}105 \\
100\end{array}$ & 103 & 108 & $=0,0501$ \\
\hline 22 & 15 & 35 & 0.0724 & 107 & 128 & $\begin{array}{l}108 \\
84\end{array}$ & $\begin{array}{l}0.0561 \\
0.0561\end{array}$ \\
\hline 23 & 137 & 101 & 0.0721 & 108 & 103 & $\begin{array}{l}124 \\
125\end{array}$ & $\begin{array}{l}0,0501 \\
0,5=56\end{array}$ \\
\hline $\begin{array}{l}24 \\
25\end{array}$ & $\begin{array}{l}48 \\
76\end{array}$ & 15 & 0.0719 & 109 & 19 & 21 & $0,05 \div 8$ \\
\hline $\begin{array}{l}25 \\
26\end{array}$ & $\begin{array}{l}76 \\
75\end{array}$ & $a$ & 0.0736 & 110 & 105 & 130 & 0.055 \\
\hline 27 & $\begin{array}{l}75 \\
33\end{array}$ & 47 & $\begin{array}{l}0.0715 \\
0.0706\end{array}$ & 111 & 41 & 16 & 0.0557 \\
\hline 28 & 37 & 27 & $\begin{array}{l}0.0 .0706 \\
0.0701\end{array}$ & 112 & ${ }_{104}^{125}$ & 144 & 0.0551 \\
\hline 29 & 62 & 129 & $\begin{array}{l}0.0701 \\
0.0700\end{array}$ & 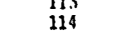 & $\begin{array}{r}104 \\
85\end{array}$ & 79 & 0.0550 \\
\hline 30 & 6.6 & 63 & 0.0698 & 115 & $\begin{array}{l}80 \\
72\end{array}$ & 102 & 0.0550 \\
\hline 31 & 110 & 13 & 0.0697 & $1: 6$ & $\sqrt{3}$ & $\begin{array}{l}52 \\
77\end{array}$ & $\begin{array}{l}0.0558 \\
0.0544\end{array}$ \\
\hline 32 & 90 & 114 & 0.0694 & 117 & $144^{3}$ & 36 & $\begin{array}{l}0.0544 \\
0.0542\end{array}$ \\
\hline 33 & ${ }_{63}^{1}$ & 105 & 0.0632 & 118 & 6 & 164 & 0.0541 \\
\hline $\begin{array}{l}34 \\
35\end{array}$ & 169 & 88 & 0.0699 & 119 & 28 & 57 & 0.0540 \\
\hline 38 & $\begin{array}{l}689 \\
161\end{array}$ & $\begin{array}{l}39 \\
54\end{array}$ & 0.0588 & 120 & 134 & 128 & 0.0539 \\
\hline 37 & $\begin{array}{l}101 \\
4\end{array}$ & $\begin{array}{r}54 \\
121\end{array}$ & $\begin{array}{l}0.0086 \\
0.0685\end{array}$ & 1.23 & 120 & 30 & 0.0538 \\
\hline 3 & 96 & $\begin{array}{r}21 \\
66\end{array}$ & $\begin{array}{l}0.0065 \\
0.0694\end{array}$ & ${ }_{122}^{122}$ & 77 & 90 & 0.0537 \\
\hline 39 & 27 & $\begin{array}{l}00 \\
116\end{array}$ & $\begin{array}{l}0.0684 \\
0.0682\end{array}$ & $\begin{array}{l}123 \\
124\end{array}$ & $\begin{array}{l}119 \\
132\end{array}$ & 82 & $\begin{array}{l}0.033 \\
0.0356\end{array}$ \\
\hline 40 & 157 & 55 & 0.0630 & $\begin{array}{l}124 \\
125\end{array}$ & $\begin{array}{c}132 \\
88\end{array}$ & $\begin{array}{l}83 \\
81\end{array}$ & $\begin{array}{l}0.05555 \\
0.5535\end{array}$ \\
\hline 41 & 26 & 7 & 0.0630 & 126 & $\begin{array}{l}10 \\
91\end{array}$ & $\begin{array}{l}81 \\
138\end{array}$ & $\begin{array}{l}0.0533 \\
0.0534\end{array}$ \\
\hline 42 & 32 & 95 & 0.0578 & 127 & 106 & 160 & $\begin{array}{l}0.0534 \\
0.05: 6\end{array}$ \\
\hline 43 & 149 & 1 & 0.0677 & 128 & 155 & 148 & 0.0525 \\
\hline $\begin{array}{l}48 \\
45\end{array}$ & 102 & $\begin{array}{ll}14 \\
65\end{array}$ & 0.0676 & 120 & 147 & 43 & 0.0523 \\
\hline $\begin{array}{l}45 \\
46\end{array}$ & 123 & $\begin{array}{l}65 \\
64\end{array}$ & 0.0671 & 30 & so & 163 & 0.0520 \\
\hline 47 & $\begin{array}{r}23 \\
89\end{array}$ & $\begin{array}{l}64 \\
29\end{array}$ & $\begin{array}{l}0.0670 \\
0.0666\end{array}$ & 131 & 80 & 40 & 0.0519 \\
\hline 48 & $\begin{array}{l}89 \\
112\end{array}$ & 126 & $\begin{array}{l}0.0066 \\
0.0665\end{array}$ & 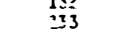 & $\begin{array}{l}84 \\
97\end{array}$ & $\begin{array}{l}41 \\
59\end{array}$ & 0.0516 \\
\hline 49 & 21 & 46 & $\begin{array}{l}.0 .0654 \\
0.0564\end{array}$ & 134 & $\begin{array}{r}97 \\
121\end{array}$ & $\begin{array}{r}59 \\
115\end{array}$ & $\begin{array}{l}0.0511 \\
0.015\end{array}$ \\
\hline 50 & 31 & 111 & 0.0663 & 135 & 74 & 103 & $0,05 \$ 3$ \\
\hline 51 & 142 & 36 & 0.0662 & $\begin{array}{l}136 \\
136\end{array}$ & $\begin{array}{l}150 \\
150\end{array}$ & $\begin{array}{l}103 \\
143\end{array}$ & 0.0510 \\
\hline 52 & 117 & 容 & 0.0661 & 137 & 82 & 91 & 0,0503 \\
\hline $\begin{array}{l}53 \\
54\end{array}$ & 42 & 87. & 0.0561 & 1139 & 136 & 141 & 0,0504 \\
\hline $\begin{array}{l}54 \\
55\end{array}$ & $\begin{array}{l}16 \\
64\end{array}$ & 20 & 0.0552 & 139 & 61 & 122 & 0.0503 \\
\hline 56 & $\begin{array}{r}64 \\
14 !\end{array}$ & $\begin{aligned} 104 \\
5\end{aligned}$ & 0.0045 & 140 & 44 & 67 & 0.0500 \\
\hline 57 & $\frac{12 !}{5}$ & 78. & $\begin{array}{l}0,0,0472 \\
0,0641\end{array}$ & $\begin{array}{l}141 \\
142\end{array}$ & $\begin{array}{l}98 \\
49\end{array}$ & 144 & 0.0500 \\
\hline 58 & 108 & 72 & 0.0540 & $\begin{array}{l}142 \\
143\end{array}$ & $\begin{array}{r}49 \\
118\end{array}$ & $\begin{array}{l}156 \\
99\end{array}$ & $\begin{array}{r}0.0490 \\
0.98\end{array}$ \\
\hline 59 & 79 & 107 & 0.0640 & 144 & $\begin{array}{l}118 \\
162\end{array}$ & $\begin{array}{l}99 \\
70\end{array}$ & 0.0488 \\
\hline 60 & 145 & 37 & 0.0639 & 145 & $\begin{array}{l}106 \\
140\end{array}$ & 131 & 0,0184 \\
\hline $\begin{array}{l}6 \lambda \\
47\end{array}$ & 105 & 153 & 0.0638 & 146 & 154 & $\begin{array}{l}131 \\
69\end{array}$ & $\begin{array}{l}0,0.0184 \\
0,0483\end{array}$ \\
\hline 63 & 57 & 97 & 0.0637 & 147 & 23 & 140 & 0,0492 \\
\hline 64 & $\begin{array}{r}115 \\
68\end{array}$ & $\begin{array}{l}80 \\
76\end{array}$ & 0.0632 & 148 & 87 & 145 & 0.0477 \\
\hline 65. & 116 & $\begin{array}{l}70 \\
73\end{array}$ & $\begin{array}{l}0.0061 \\
0.0627\end{array}$ & $\begin{array}{l}149 \\
150\end{array}$ & $124^{2}$ & 157 & 0.0477 \\
\hline 66 & 152 & 118 & 0.0527 & 151 & 165 & $\begin{array}{l}89 \\
45\end{array}$ & $\begin{array}{l}0.0475 \\
0.0474\end{array}$ \\
\hline 67 & 39 & 23 & 0.0623 & 152 & 20 & 152 & 0,0473 \\
\hline 68 & 54 & 68 & 0.0623 & 153 & 43 & 74 & 0.0473 \\
\hline 69 & 46 & (iti) & 0.0621 & is: & 47 & 168 & 0.0470 \\
\hline 71 & $\begin{array}{c}164 \\
81\end{array}$ & $\begin{array}{r}6 \\
50^{\circ}\end{array}$ & $\begin{array}{l}0,0620 \\
0.0088\end{array}$ & $\begin{array}{l}155 \\
156\end{array}$ & 153 & 113 & 0.0456 \\
\hline 72 & $\begin{array}{l}81 \\
13\end{array}$ & $\begin{array}{r}50 \\
154\end{array}$ & $\begin{array}{l}0.0608 \\
0.0608\end{array}$ & $\begin{array}{l}156 \\
157\end{array}$ & $\begin{array}{l}94 \\
95\end{array}$ & 22 & 0.0465 \\
\hline 73 & 71 & $\begin{array}{r}154 \\
38\end{array}$ & $\begin{array}{l}.0008 \\
.0006\end{array}$ & $\begin{array}{l}157 \\
158\end{array}$ & $\begin{array}{l}95 \\
52 \\
52\end{array}$ & $\begin{array}{l}147 \\
32\end{array}$ & $\begin{array}{l}0.0488 \\
0.0547\end{array}$ \\
\hline 74 & 67 & 30 & 0.0606 & $\begin{array}{l}159 \\
159\end{array}$ & 8 & 150 & 0.0445 \\
\hline 75 & 130 & 53 & 0.0603 & 160 & 85 & 133 & 0.0 .44 \\
\hline 76 & 92 & 146 & 0.0603 & 51 & 73 & [37 & $\begin{array}{l}0.0433 \\
0.04\end{array}$ \\
\hline 77 & 159 & 105 & 0.0602 & 162 & 133 & 166 & 0.0422 \\
\hline 78 & 100 & 42 & 0.0631 & 163 & 11 & 165 & 0.0420 \\
\hline $\begin{array}{l}79 \\
80\end{array}$ & $\begin{array}{r}70 \\
158\end{array}$ & 34 & 0.0599 & 164 & 169 & is & 0.0107 \\
\hline $\begin{array}{l}80 \\
81\end{array}$ & $\begin{array}{r}158 \\
83 \\
-10\end{array}$ & $\begin{array}{l}3122 \\
134\end{array}$ & $\begin{array}{l}0.0556 \\
0.05196\end{array}$ & $\begin{array}{l}165 \\
166\end{array}$ & 143 & 15.9 & 0.0386 \\
\hline 82 & 122 & $\begin{array}{l}134 \\
06\end{array}$ & $\begin{array}{l}0.03516 \\
0.0525\end{array}$ & 166 & 14 & 124 & 0.0356 \\
\hline 83 & 129 & 155 & $\begin{array}{l}0.03513 \\
0.0514\end{array}$ & 168 & 101 & 159. & 0.039 .9 \\
\hline 84 & 32 & 132 & 0.0553 & $\begin{array}{l}108 \\
169\end{array}$ & $\begin{array}{r}30 \\
156\end{array}$ & $\begin{array}{l}167 \\
163\end{array}$ & 0.02 .48 \\
\hline 85 & 146 & 130 & 0.0591 & & & & 0.01 .40 \\
\hline
\end{tabular}


Considerando-se o citado, e o comportamento das progênies de Eucalyptus saligna Smith, como verificado na Figura 7 , esse comportamento sugere que a espécie apresentou mais características de espécie pioneira, reagindo mais favorave1mente em espaçamentos mais amplos, onde disporâ de maior quantidade de luz.

$$
\text { Quando observado o espaçamento } 3,0 \times 1,0 \mathrm{~m} \text {, }
$$

percebe-se que o número de progênies que sobressaíram é menor, do que no $3,0 \times 2,0 \mathrm{~m}$ e que muitas das progênies que apresentaram boa produtividade no espaçamento apertado corres ponderam a aquelas progênies que apresentaram um bom desenvol vimento em ambos os espaçamentos, e que geralmente também ocu param uma posição semelhante no espaçamento mais amplo. Esse fato confirmaria o salientado por KAGEYAMA (1986) sobre a res posta heterogênea face ao espaçamento.

Esse comportamento diferencial das progênies face ao espaçamento, poderia ser aproveitado para a obtenção de progênies que possam ser utilizadas para fins diferentes. Assim aquelas que apresentaram o melhor comportamento em espa çamentos apertados, seriam utilizadas em programas visando a produção de lenha para energia, ou materiais finos para outros usos, enquanto que as melhores progênies no espaçamento mais amplo poderiam ser utilizadas em programas visando a obtenção de celulose, chapas de fibra, etc.

Quando analisada a Figura 7 verifica-se a presença de interações dos tipos denominados por FONSECA (1979) 
como sendo interações simples e interações complexas. E importante salientar que essás interações ocorreram tanto na faixa daquelas consideradas como sendo as melhores em produção volumêtrica por ârvore, como em aquelas consideradas como sendo as piores produtoras, em ambos os espaçamentos.

Por exemplo, quando consideradas as progênies 36 e 149, que foram as melhores nos espaçamentos mais amplo e mais apertado, respectivamente, verificou-se uma interação complexa, se bem que, quando comparadas as produções de cada uma das progênies nos dois espaçamentos $\left(0,1426 \mathrm{~m}^{3} /\right.$ ârvore para a progênie 35 e $0,1460 \mathrm{~m}^{3}$ /árvore para a 149), percebe-se que a diferença da produção das progênies nos dois espaçamentos $\vec{e}$ mínima $\left(0,0034 \mathrm{~m}^{3} /\right.$ ärvore $)$.

Na faixa das piores progênies, tambëm existem interações complexas como a verificada entre as progênies 156 e 47, que ocuparam as piores posições nos espaçamentos de 3,0 x 2,0 m e de $3,0 \times 1,0 \mathrm{~m}$, respectivamente. Nesse caso a produ ção de cúda uma das progênies quando considerados conjuntamen te os dois espaçamentos foi de $0,0643 \mathrm{~m}^{3} /$ árvore para a progênie 156 e de $0,0812 \mathrm{~m}^{3} /$ ärvore para a 47 . A diferença entre as progênies consideradas, é bem maior $\left(0,0169 \mathrm{~m}^{3} / a ̄ r v o r e\right)$ do que no caso acima.

Na faixa das progênies que apresentaram valores de produção em volume perto da médja da população de progênies, também foram verificadas interações complexas, por exemplo, entre as progênies 129 e 94, as que apresentaram me- 
Thor comportamento no espaçamento $3,0 \times 2,0 \mathrm{~m}$ e $\quad 3,0 \times$ $1,0 \mathrm{~m}$ respectivamente, nas quais apresentaram-se produções con-

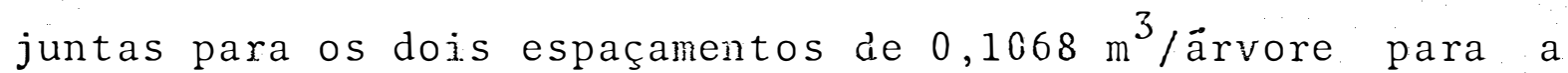

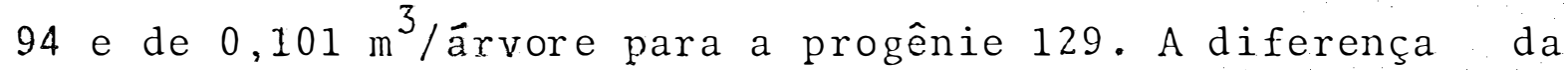
produção conjunta dos dois espaçamentos para ambas as progêê nies foi de $0,006 \mathrm{~m}^{3} / \vec{a}$ rvore.

Os exemplos de interações complexas são numero sos entre as 169 progênies, em todas as posições considerando a produção volumétrica, sendo que as diferenças de produção entre elas geralmente apresentam os níveis considerados aci-ma.

Ainda que a maior parte das progênjes não mostram interações, e que as diferenças entre elas são não signi ficativas, as poucas progênies que apresentaram interações, e boa produção volumétrica em qualquex dos espaçamentos, devem ser aproveitadas na seleção dentro de um programa de melhora mento.

\subsection{CORRELACÃO ENTRE OS ESPAC,AMENTOS PARA AS DifERENTES CARACTERISTICAS}

A quantificação da ussociação entre as mêdias das progênies nos dois espaçamentos testados aos 32 meses de idade e utilizando-se o "Coeficiente de Correlação de Spearman" $\left(\mathrm{r}_{\mathrm{s}}\right)$, pode ser visualizada na Tabela 17 a seguir. 
Tabela 17 - Coeficientes de correlação de Spearman entre os dois espraçamentos, ao nível de mêdias de parcelas, para as características altura, diâmetro, volume cilíndrico e forma das árvores, à idade de 32 meses.

Característica

Coeficiente de correlação de Spearman $\left(\mathrm{r}_{\mathrm{S}}\right)$

Altura

$0,62 * *$

Diânetro (dap)

$0,50^{* *}$

Volume cilíndrico

$0,52^{* *}$

Forma do tronco ${ }^{1}$

$0,37 *$

** significativo ao nível de $1 \%$, pelo teste $t$.

* significativo ao nivel de 5\%, pelo teste $t$.

1 utilizando-se só as 4.2 melhores progênies em produção volumêtrica no espaçamento $3,0 \times 2,0 \mathrm{~m}$.

Os resultados obtidos mostram correlações posi tivas entre os dois espaçamentos appresentando valores signifi cativos ao nível de $1 \%$ para as características de crescimen to, e ao nível de $5 \%$ para forma do tronco. Essas estimativas mostram a existência de correlação, para as características estudadas de um para outro espaçamento, fato que ê mais acentuado para altura, diâmetro e volum cilíndrico. No entanto, observa-se que os valores de $r_{s}$ não são expressivos, mostrando uma não concordância nas posiçöes relativas das progênies nos dois espaçamentos, o que indicaria a existência de alguma 
interação de progênies por espaçamentos, advinda, segundo VEN COVSKY (1978), da falta de correlação entre o material de um ambiente para outro.

\subsection{EstimaÇÃO DE VARIÂNCIAS GENÉTICAS E NÃO GENËTICAS E DE COEFICIENTES DE HERDABILIDADE E DE VARIAÇÃO GENË- TICAS E NÃO GENÉTICAS PARA ALTURA, DIÂMETRO, ÁREA BA SAL, VOLUME CILÍNDRICO E FORMA DO TRONCO}

As estimativas das variâncias genêticas e nao genëticas para as características de crescimento e para forma do tronco, obtidas a partir dos componentes de variâncias das anâlises individuais em látice e blocos ao acaso, envolvendo as idades consideradas e os dois espaçamentos, são apresentados na Tabela 18, para as análises individuais e na Tabela 19 para as análises conjuntas.

As estimativas das variâncias genëticas entre progênies, para todas as características estudadas apresentaram erros associados variando de $2,68 \%$ a $8,88 \%$, o que mostra que essas estimativas foram obtidas com boas precisões.

Essas estimativas, quando considerados os dois delineamentos utilizados, variaram de $2,68 \%$ a $7,47 \%$ no de 1 ineamento eln látice e de $2,96 \%$ a $8,88 \%$ no de blocos ao acaso. Os valores desses erros associados foram sempre maiores no de lineamento em blocos ao acaso do que no de látice, quando com 
Tabela 18 - Estimativas das variâncias genēticas e não genéticas e dos erros associados nos dois espaçamentos testados, as idades de 26 e 32 meses, para os dois delineamentos utilizados.

\begin{tabular}{|c|c|c|c|c|c|c|c|c|c|}
\hline \multirow{3}{*}{$\begin{array}{l}\text { Delineasento } \\
\text { Espacanento } \\
\text { Idade (meses) }\end{array}$} & & \multicolumn{4}{|c|}{ Läzice } & \multicolumn{4}{|c|}{ Blocos ac 8c3so } \\
\hline & & \multicolumn{2}{|c|}{$3,0 \times 1,0$} & \multicolumn{2}{|c|}{$3,0 \times 2,0$} & \multicolumn{2}{|c|}{$3,0 \times 1,0$} & \multicolumn{2}{|c|}{$3,0 \times 2,0$} \\
\hline & & 26. & 32 & 26 & 32 & 26 & 32 & 28 & 32 \\
\hline Carseteristicas & Paränetros & & & & & . & & & \\
\hline \multirow{6}{*}{ Altuts (o) } & $\sigma^{2} d$ & 2,158 & 2,6359 & 1,9903 & 2,5493 & 2,158 & 2,6359 & 1,9503 & 2,5493 \\
\hline & $\sigma^{2} 0$ & 0,3753 & 0,3324 & $0,35 s 1$ & 0,4007 & 0,5037 & 0,4394 & 0,4865 & 0,4893 \\
\hline & $\sigma^{2} 8$ & 0,1425 & 0,1153 & 0,1991 & 0,2385 & 0,1399 & 0,1513 & 0,1898 & 0,2272 \\
\hline & $s\left(0^{2} p\right)$ & 0,00393 & 0,009165 & 0,00896 & 0,010834 & 0,00434 & 0,00448 & 0,00546 & 0,0111 \\
\hline & (घ) & 2,75 & 3.68 & 4,50 & 4,54 & 6,76 & 2,96 & 4,93 & 4,87 \\
\hline & $\sigma^{2 A}$ & 0,57 & 0,6212 & 0,7954 & 0,954 & 0,5596 & 0,6052 & 0,7592 & 0, suss \\
\hline \multirow[t]{2}{*}{ 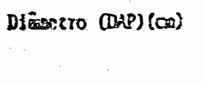 } & $\sigma^{2} d$ & 2,5571 & 3,602 & 2,7053 & 3,9009 & 2,5571 & 3,602 & 2,7053 & 3,9004 \\
\hline & $\sigma^{2} \theta$ & 0,1014 & 0,1040 & 0,1538 & 0.2010 & 0,2339 & 0,2691 & 0,2826 & 0,3509 \\
\hline \multirow{4}{*}{. } & $0^{2} \mathrm{p}$ & 0,0795 & 0.1071 & 0,1471 & 0,1995 & 0,0856 & 0,1160 & 0,1394 & 0,1952 \\
\hline & $s\left(\sigma^{2} p\right)$ & $0,002: 47$ & 0,003169 & 0,00744 & 0,01049 & 0,002897 & 0,00385 & 0,00804 & $0,01128:$ \\
\hline & (1) & 2,95 & 2,96 & 5,05 & 3,26 & $3 x$ & 3,32 & 5,27 & 5,78 \\
\hline & $\sigma^{2} A$ & 0,318 & 0,4284 & 0,5864 & 0,798 & 0,3424 & 0,454 & 0,5576 . & 0,7808 \\
\hline \multirow{6}{*}{$\begin{array}{l}\text { Lrea basal } \\
\text { (no' /ervure) }\end{array}$} & $\sigma^{2} d$ & $1,978 \times 10^{-6}$ & $\therefore, 84 \times 10^{-6}$ & $2,924 \times 10^{-6}$ & $5,28 \times 10^{-6}$ & $1,978 \times 10^{-6}$ & $4,34 \times 10^{-6}$ & $2,924 \times 10^{-6}$ & $5,28 \times 10^{-6}$ \\
\hline & $\sigma^{2} \theta$ & $1,90 \times 10^{-7}$ & $1,175 \times 10^{-7}$ & $2,254 \times 10^{-7}$ & $4,06 \times 10^{-7}$ & $3,443 \times 10^{-7}$ & $3,326 \times 10^{-7}$ & $4,125 \times 10^{-7}$ & $6,5: 1 \times 10^{-7}$ \\
\hline & $c^{2} p$ & $6.86 \times 10^{-8}$ & $1,044 \times 10^{-7}$ & $1,32 \times 10^{-7}$ & $2,02 \times 10^{-7}$ & $8,01 \times 10^{-8}$ & $1,226 \times 10^{-7}$ & $1,26 \times 10^{-7}$ & $1,0,4 \times 10^{-7}$ \\
\hline & $s\left(c^{2} p\right)$ & $2,336 \times 10^{-9}$ & $3,70 \times 10^{-9}$ & $7,851 \times 10^{-9}$ & $1,364 \times 10^{-8}$ & $2,9373 \times 10^{-9}$ & $4,674 \times 10^{-9}$ & $8,814 \times 10^{-9}$ & $1,532 \times 10^{-8}$ \\
\hline & (1) & 3,40 & 3,54 & 5,95 & 6,75 & 3,73 & 3,81 & 7,10 & 7,80 \\
\hline & $a^{2} A$ & $2,744 \times 10^{-7}$ & $4,175 \times 10^{-7}$ & $5,28 \times 10^{-3}$ & $8,08 \times 10^{-7}$ & $5,204 \times 10^{-7}$ & $1.904 \times 10^{-7}$ & $4,90 \times 10^{-7}$ & $7,86 \times 10^{-7}$ \\
\hline \multirow{5}{*}{ 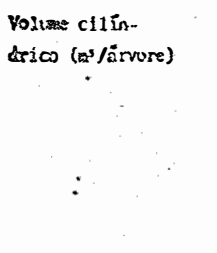 } & $\sigma^{2} d$ & $4,287 \times 10^{-4}$ & $?, 965 \times 10^{-4}$ & $4,722 \times 10^{-4}$ & $9,571 \times 10^{-4}$ & $4,287 \times 10^{-4}$ & $7,965 \times 10^{-4}$ & $4,722 \times 10^{-4}$ & $9,571 \times 10^{-4}$ \\
\hline & $0^{2} 0$ & $3,76 \times 10^{-5}$ & $5,35 \times 10^{-5}$ & $5,95 \times 10^{-5}$ & $1,114 \times 10^{-4}$ & $6,559 \times 10^{-5}$ & $9,415 \times 10^{-5}$ & $9, s(1)=10^{-5}$ & $1,71 \times 10^{-4}$ \\
\hline & $\begin{array}{l}v^{2} p \\
s\left(\sigma^{2} p\right)\end{array}$ & $\begin{array}{l}1,28 \times 10^{-5} \\
4,642 \times 10^{-7}\end{array}$ & $\begin{array}{l}2,23 \times 10^{-5} \\
7,75 \times 10^{-7}\end{array}$ & $\begin{array}{l}2,05 \times 10^{-5} \\
1,433 \times 10^{-5}\end{array}$ & $\begin{array}{l}3,79 \times 10^{-5} \\
2,74 \times 10^{-6}\end{array}$ & $\begin{array}{l}1,502 \times 10^{-5} \\
5,8762 \times 10^{-7}\end{array}$ & $\begin{array}{l}3,448 \times 10^{-5} \\
9,6184 \times 10^{-7}\end{array}$ & $\begin{array}{l}2,05 \times 30^{-5} \\
1,041 \times 10^{-6}\end{array}$ & $\begin{array}{l}3,667 \times 10^{-5} \\
3,070 \times 10^{-5}\end{array}$ \\
\hline & (i) & 3,09 & 3,16 & 6,59 & 7,47 & 3,51 & 3,93 & 8,0 & 8,37 \\
\hline & $\sigma^{2} A$ & $5,12 \times 10^{-5}$ & $8,92 \times 10^{-5}$ & $8,2 \times 10^{-5}$ & $1,516 \times 10^{-4}$ & $0.008 \times 10^{-5}$ & $9,792 \times 10^{-5}$ & $8,2 \times 10^{-6}$ & $1,47 \times 10^{-4}$ \\
\hline \multirow{6}{*}{$\begin{array}{l}\text { Forsea do tronco } \\
\text { (sotes) }\end{array}$} & $o^{2} d$ & - & $=$ & - &. & - & 0,4618 & * & 0,4381 \\
\hline & $c^{2} \theta$ & - & $*$ & - & - & * & 0,0550 & - & 0,052 \\
\hline & $\sigma^{2} p$ & - & - & - & - & - & 0,01304 & - & 0,063 \\
\hline & $8\left(\sigma^{2} p\right)$ & - & - & - & - & - & 0,00116 & * & 0,00258 \\
\hline & (3) & - & - & - & - & - & 8,88 & $\cdot$ & 4,10 \\
\hline & $O^{2} A$ & $-\ldots \ldots$ & $\therefore$ & $\therefore$ & $\cdots \cdots \therefore$ & $\therefore$ & 0,0522 & $*$ & 0,252 \\
\hline
\end{tabular}

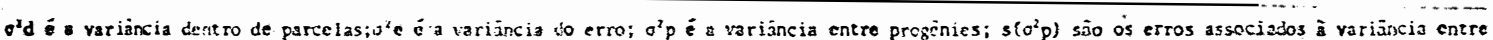

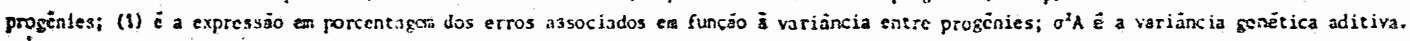




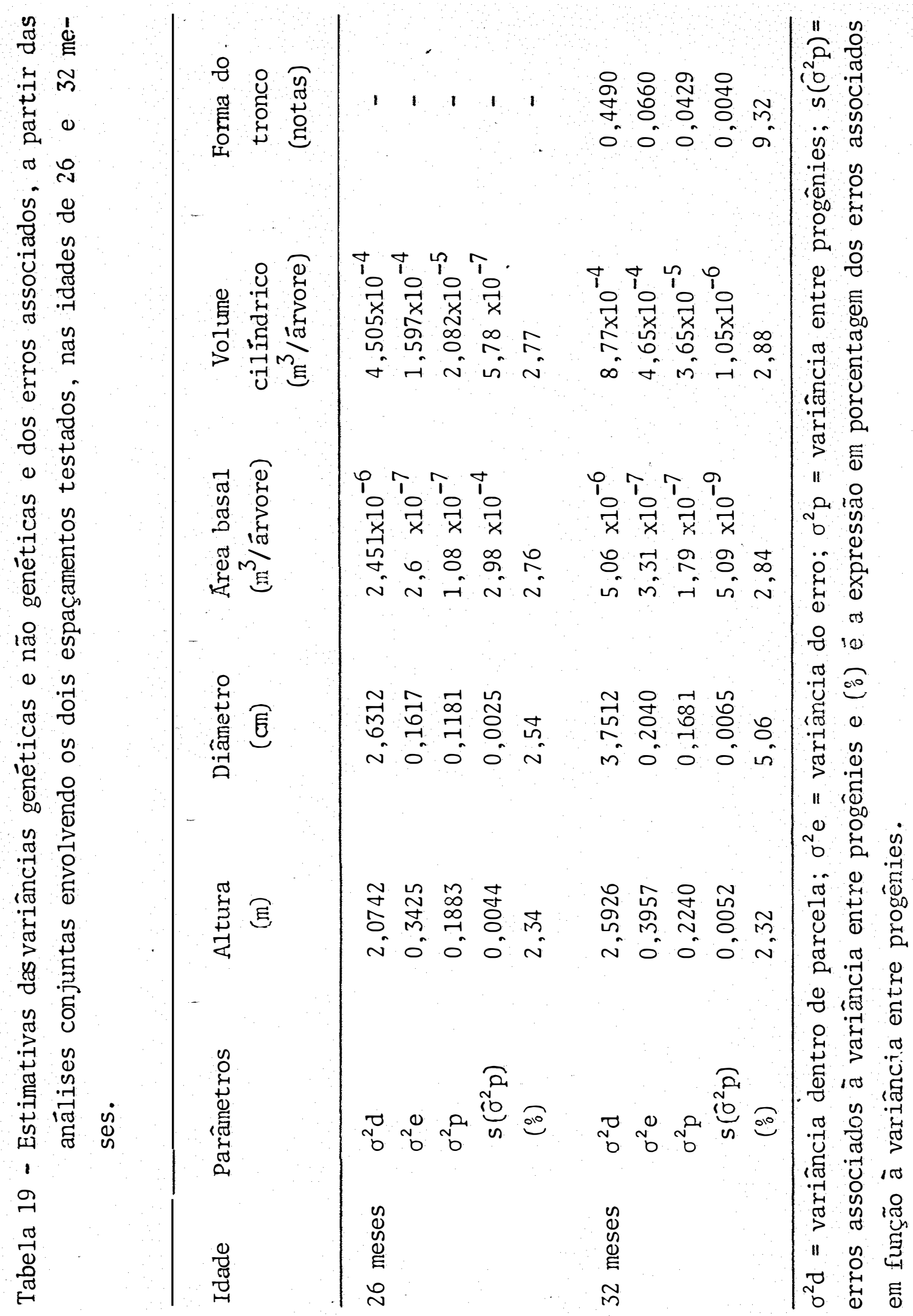


parados a mesma característica, idade e espaçamento, sugerindo que as estimativas da váriância entre progênies e, consequentemente, as herdabilidades obtidas, no caso decorrente, a presentaram melhores precisões no delineamento em látice do que no de blocos ao acaso. Esse fato poderia ser explicado considerando-se as altas eficiências dos látices realizados, que permitiram essa maior sensibilidade na determinação desses parâmetros.

Nas análises conjuntas, os erros associados à variância entre progênies apresentaram valores variando de $2,32 \%$ a $5,06 \%$, à idade de 32 meses, e de $2,34 \%$ a $2,77 \%$, ̀̇ ida de de 26 meses, mostrando uniformemente uma boa precisão para as estimativas.

As estimativas de variância devida à interação de progênics $x$ espaçamentos apresentaram-se com valores negativos, considerando-se portanto como sendo iguais a zero, fato que foi demonstrado por Searle (1971), citado por PIRES (1984), não sendo então considerâras para estimar a variância fenotipica e a herdabilidade.

Em geral os erros associados obtidos para as progênies de Eucalyptus saligna Smith, foram coerentes com aqueles reportados por KAGEYAMA (1980) para as características de altura, diâmetro e volume de E. grandis Hill ex Maiden e por PINTO JR. (1984) para progênies de: E. urophylla E.T. Blake. 
As estinativas de variâncias genéticas aditivas foram obtidas a partir das variâncias genëticas entre pro gênies, sendo portanto proporcionais a estas ūltimas. Os erros padrões das estimativas das variâncias entre progênies, são portanto equivalentes aos das estimativas das variâncias genéticas aditivas.

As estimativas de herdabilidade obtidas para as progênies, para as três idades e os dois espaçamentos considerados, são mostradas na Tabela 20 , a seguir.

E importante salientar que para se estimar os coeficientes de herdabilidade, as progênies de Eucalyptus saligna Smith foram consideradas como sendo de meios-irmãos, e que a ocorrência de endogamia na população de Itatinga foi ne gligível. Segundo coloca NAMKOONG (1966), a presença de endogamia, pela ocorrência de autofecundação ou pela restrição no tamanho efetivo da população, pode inflar as estimativas das variâncias genéticas nos testes de progênies de polinização a berta.

Os valores encontrados para as estimativas da herdabilidade no sentido restritio e ao nível de plantas individuais variaram tanto entre os espaçamentos testados como en tre as características consideradas, quando comparadas as diferentes idares nos dois delineamentos utilizados.

Na Figura 8 pode ser melhor visualizada a evolução dos coeficientes de herdabilidade para os dois espaçamentos e as três idades avaliadas, para cada um dos delinea- 


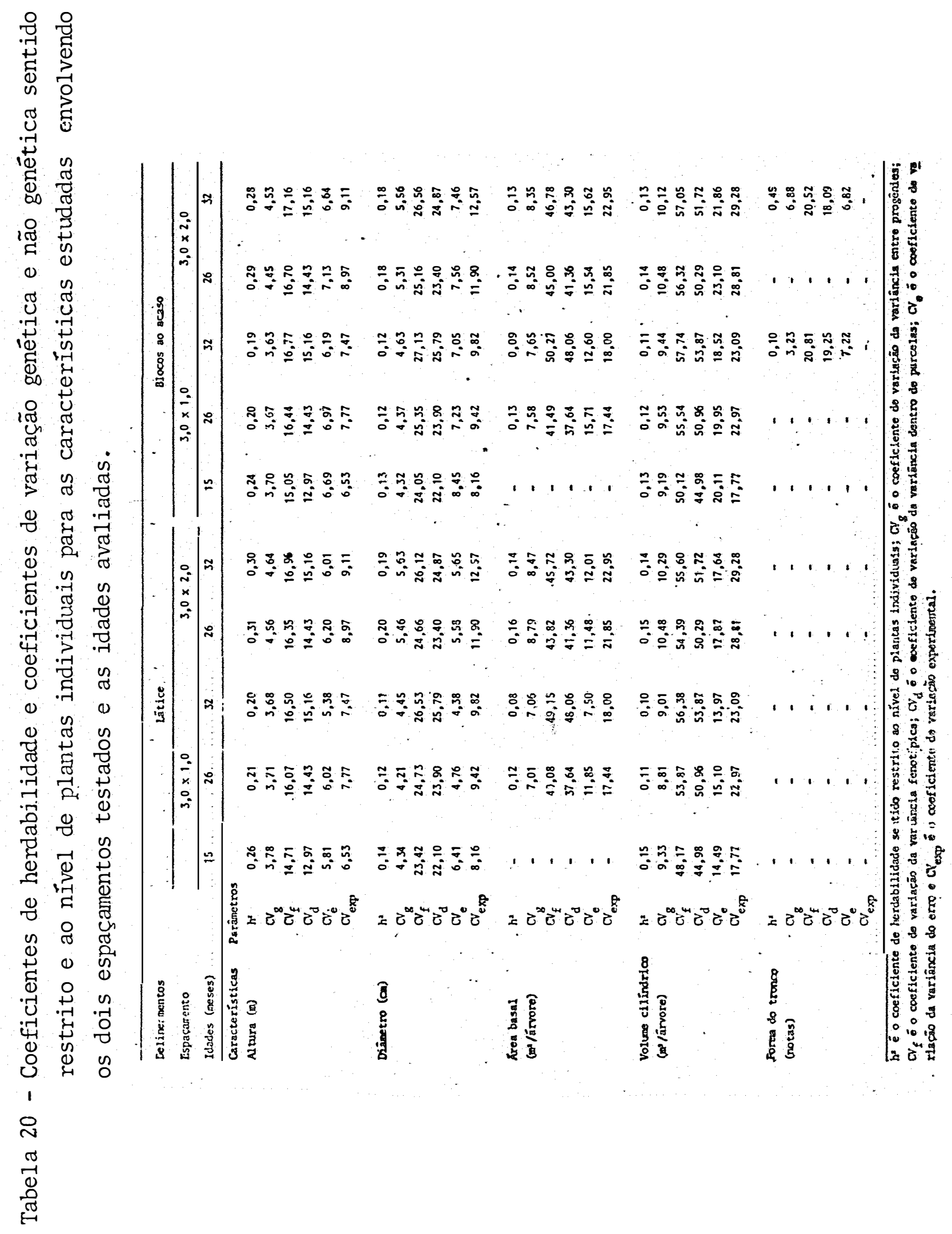



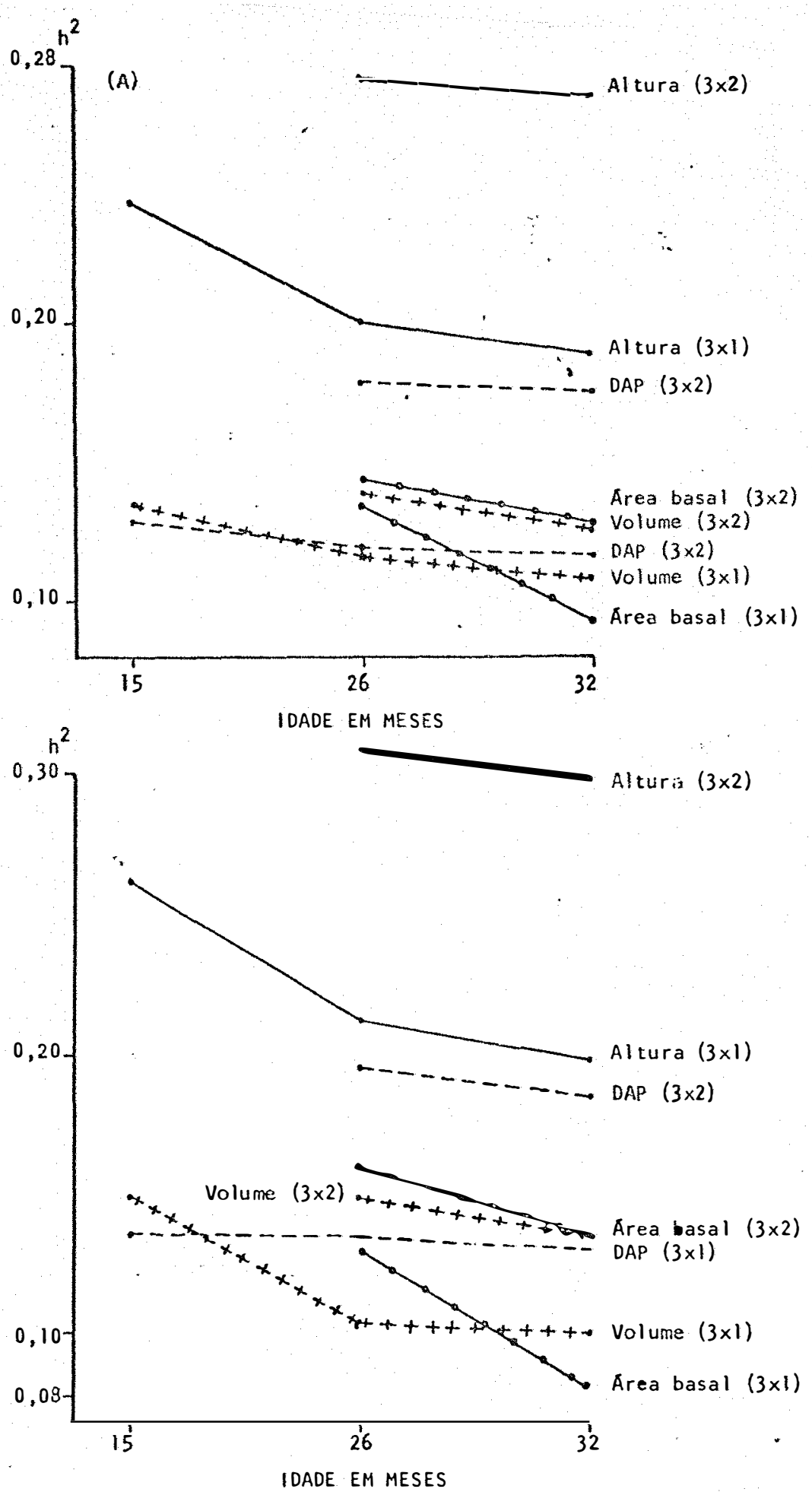

Figura 8 - Evolução dos coeficientes de herdabilidade $\left(h^{2}\right)$ em função da $\underline{i}$ dade e dos espaçamentos para âs análises individuais em blocos ao acaso (A) e em lätice (B). 
mentos utilizados.

A herdabilidade no sentido restrito ao nivel de plantas individuais apresentou uma tendência de decrescer com a idade, com uma queda maior dos 15 para os 26 meses de dade, e uma queda menos acentuada dos 26 para os 32 meses de idade. Os coeficientes de herdabilidade para as características de crescimento mostraram uma mesma tendência nos dois espaçamentos testados e nos dois delineamentos utilizados.

O decréscimo do coeficiente de herdabilidade com o aumento da idade poderia ser explicado, segundo KAGEYAMA (1983), tanto pela diminuição da quantidade de variação gב nética como do aumento da variação fenotípica. Por sua vez FRANKLIN (1979) explica o decréscimo do coeficiente de herdabilidade com a idade, como sendo devido aos efeitos da competição entre plantas, indicando que conforme a competição e.ttre as plantas aumenta, o coeficiente de herdabilidade diminui, se bem que esse valor pode crescer novamente à medida que as ärvores atingem a maturidade. Esse padrão de variação da herdabilidade, continua FRANKLIN, principalmente nas características de crescimento, tambẻm é função da presença ou não de diferentes genes controlando o crescimento das árvores independentemente do ambiente em que essas ärvores se desenvol vem.

KAGEYAMA (1983), citando Kremer (1981), relata que o coeficiente de herdabilidade para altura em Pinus pinas ter aumentou-se com a idade até os 12 anos, decorrente de uma 
estabilidade para a variância entre famílias e uma diminuição da variância do erro e, em decorrência, também uma diminuição da variância fenotípica.

A diminuição dos valores dos coeficientes de herdabilidade com a j.dade, foi generalizada para todas as características nos dois espaçamentos testados e nos dois delineamentos utilizados, exceto para o diâmetro, característica onde o coeficiente de herdabilidade se estabilizou dos 26 para os 32 meses de idade, em ambos os espaçamentos no delinea mento em blocos ao acaso.

Os reslittados obtidos para os coeficientes de herdabilidade e a tendência de diminuição com a idade são coe rentes com aqueles obtidos por KAGEYAMA (1983) para Eucalyptus grandis Hill ex Maiden, por ELDRIDGE (1972) para o E. reg nans F. Muell e por VAN WIK (1976) para O E. grandis Hill ex Maiden .

Quando considerado o espaçamerto maior, verifi cou-se una tendência de maiores valores de herdabilidade para o delineamento em látice do que no de blocos ao acaso. Para as características de diâmetro, ảrea basal e volume cilíndrico, no espaçamento menor, não foi verificada nenhuma tendência. Por outro lado, a altura das plantas apresentou maiores valores de herdabilidade no delineamento em lätice e no espaçamento mais amplo do que no de blocos ao acaso e espaçamento $3,0 \times 1,0 \mathrm{~m}$.

O coeficiente de herdabilidade no sentido res- 
trito ao nível de plantas para diâmetro, área basal e volume cilindrico apresentaram-se como sendo sempre maiores no espaçamento mais amplo do que no mais apertado, em ambos os delineamentos utilizados. A evolução dos coeficientes mostra que a queda jâ citada para todas as características de crescimento com o decorrer da idade, foi mais acentuada para a área ba sal no espaçamento $3,0 \times 1,0 \mathrm{~m}$ do que no $3,0 \times 2,0 \mathrm{~m}$, em ambos os delineamentos, o que pode ser explicado considerando que a idade de 32 meses e no espaçamento mais apertado, a competi ção entre as plantas é bem grande o qual pode influir, como sa lientado por KAGEYAVA (1983) na diminuição da variação genética ou ao incremento da variação fenotípica, afetando-se em con sequência o valor expresso do coeficiente de herdabilidade.

Os valores dos coeficientes de herdabilidade pa ra o volume cilindrico foram muito semelhantes nas idades de 26 e 32 meses, para ambos os espaçamentos testados, e quando considerados os dois delineamentos utilizados.

Para altura das plantas, as estimativas de her dabilidade no sentido restrito, ao lível de plantas, apresentaram uma tendência de diminuir com o aumento da idade, sendo que esse; valores foram sempre maiores no espaçamento $3,0 \mathrm{x}$ 2,0 m e no delineamento em lätice. Quando comparados os dois espaçamentus percebe-se que a queda dos valores de herdabilidade são quase que na mesma proporção em ambos os casos. Esses resultados são coerentes com aqueles obtidos por outros autores como KAGEYAMA (1983) para Eucalyptus grandis Hill ex 
Maiden, PINTO JR. (1984) para E. urophylla E.T. Blake, entre outros.

Para forma do tronco das árvores a idade de 32 meses, o coeficiente de herdabildade no sentido restrito para médias de parcelas por plantas, apresentou um incremento con siderävel do espaçamento menor $(3,0 \times 1,0 \mathrm{~m})$ para o maior $(3,0 \times$ $2,0 \mathrm{~m})$ com valores de 0,10 e 0,45 , respectivamente.

E importante se considerar que as progênies fo ram selecionadas dentro do espaçamento $3,0 \times 2,0 \mathrm{~m}$ e considerando-se as 42 melhores quanto à produção em volume nesse espaçamento. Portanto, as progênies assim selecionadas poderiam ser consideradas como progênies que se desenvolveram melhor no espaçamento mais amplo.

Esse fato sugere que as diferenças entre os coe ficientes de herdabilidade face aos dois espaçamentos, e a pre sença de maior variabilidade genética entre progênies no espa çamento maior, sejam devidas a uma resposta diferencial das progênies ao espaçamento, verificando-se a influência, no cres cimento e forma das ärvores, do espaçamento e, consequentemen te, da luz.

0 coeficiente de herdabilidade para forma do tronco no espaçamento $3,0 \times 2,0$ m mostra claramente que a for ma das ärvores das progênies de Eucalyptus saligna Smith, esteve sob maior controle genético que no espaçamento mais aper tado. Por outro lado, a baixa variabilidade genética das progênies no espaçamento menor e o consequente menor coeficiente 
de herdabilidade, demonstram que quando sob forte competição, as progênies da espécie mostram maior efeito do ambiente do que genético.

E importante salientar que, sendo o E. saligna Smith uma espécie exigente quanto a competição, o espaçamento mais apertado poderia estar disfarçando a expressão da variação para forma do tronco das árvores. Isso é reforçado observando-se o maior erro associado à variância entre progênies que ocorreu no espaçamento menor.

Considerando que a forma do tronco é citado co mo sendo de forte controle genético, e associando-se ao discu tido anteriormente, devemos considerar que a herdabilidade real para a característica é provavelmente a apresentada pelo espa çamento maior, ou mais pröxima desta.

As estimativas das hordabilidades para as características foram obtidas para cada espaçamento e idade, sem se separar a variância da interação de progênies x espaçanıntos daquela devida a progênies, sendo, portanto, vâlidas somente para as condições da localidade onde as mesmas foram de terminadas, conforme o colocado por ROBINSON e COCKERHAM (1965).

KAGEYAMA (1983) colocou o fato de que a alta variabilidade genética na idade juvenil seria importante para que as ärvores mantivessem a posição competitiva da copa "ro dossel superior do povoamento, fenômeno que nas florestas $t \propto m$ peradas acontece na idade entre 10 a 20 anos. Essa fase coincidiria com o início da preparação das ārvores para a reprodu 
ção da espécie, mantendo nessa fase um ritmo de crescimento me nor mas suficiente para a sua sobrevivência, resultarido num declínio da variação genética entre progênies ou ainda podendo-se apresentar como uma fase de estabilidade. O autor levan ta a hipótese de que para o Eucalyptus grandis Hill ex Maiden a fase até 1 ano seria comparávè à fase de 15 anos quando as espécies temperadas iniciam a sua reprodução. Nesse caso continua KAGEYAMA, a fase de aumento da variância genética aditi va com a idade poderia ter ocorrido antes da idade de 1 ano.

KAGEYAMA (1983) relata que a anâlise da evolução dos diferentes tipos de coeficientes de variação com o de correr da idade permite discutir mais fundamentalmente o decréscimo da herdabilidade. O autor verificou, para o Eucalyptus grandis Hill ex Maiden, que o decrêscimo do coeficiente de herdabilidade poderia ser explicado pelo decrésicimo mostra do pelo coeficiente de variação genética coma idade, apresentando a mesma tendência que a revelada para o coeficiente de herdabilidade. O autor sajienta, ajnda, que o coeficiente de variação àa variância do Erro, igualmente ao de variação gené tica, mostrou também um decréscimo com o decorrer da idade. Es sa tendência similar verificada para todos os coeficientes de variação refletiu-se numa diminuição abrupta do coeficiente de variação fenotípica de 1 para 2 anos de idade, estabilizan do-se esse parâmetro dos 2 para os 5 anos de idade.

0 coeficiente de variação genëtica, que expres sa em porcentagem da média geral a quantidade de variação ge- 
nética existente entre as progênies $\left(\mathrm{CV}_{\mathrm{g}}\right)$, para as caracterís ticas de altura, diâmetro, ảrea basal, volume cilíndrico nos dois espaçamentos, e nas três idades estudadas, são fornecidos na Figura 9, envolvendo os delineamentos em bjocos ao aca so em látice.

Quando se atenta para o coeficiente de varia ção genêtica $\left(\mathrm{CV}_{\mathrm{g}}\right)$, verifica-se que esse parâmetro manteve a mesma tendência para todas as características de crescimento tanto entre as idades avaliadas como entre os dois espaçamentos considerados.

A evolução dos coeficientes de variação da variância do erro para as características de crescimento estuda das, envolvendo os dois espaçamentos e as três idades conside radas pode ser observada na Figura 10 para cada um dos delineamentos utilizados.

Para as características de altura, diâmetro e volume cilíndrico, o coeficiente de variação da variância do erro, apresentou-se muito estávei, considerando-se a idade e ambos os delineamentos utilizados.

Quando considerada a ảrea basal no espaçamento menor, o coeficiente de variação da variância do erro apresen tou a tendência de se diminuir nos dois delineamentos utiliza dos. Para o espaçamento.maior apresentou-se a tendência inver sa de se incrementar ligeiramente o valor do coeficiente de variação da variância do erro com a idade.

o coeficiente de variação da variância dentro 

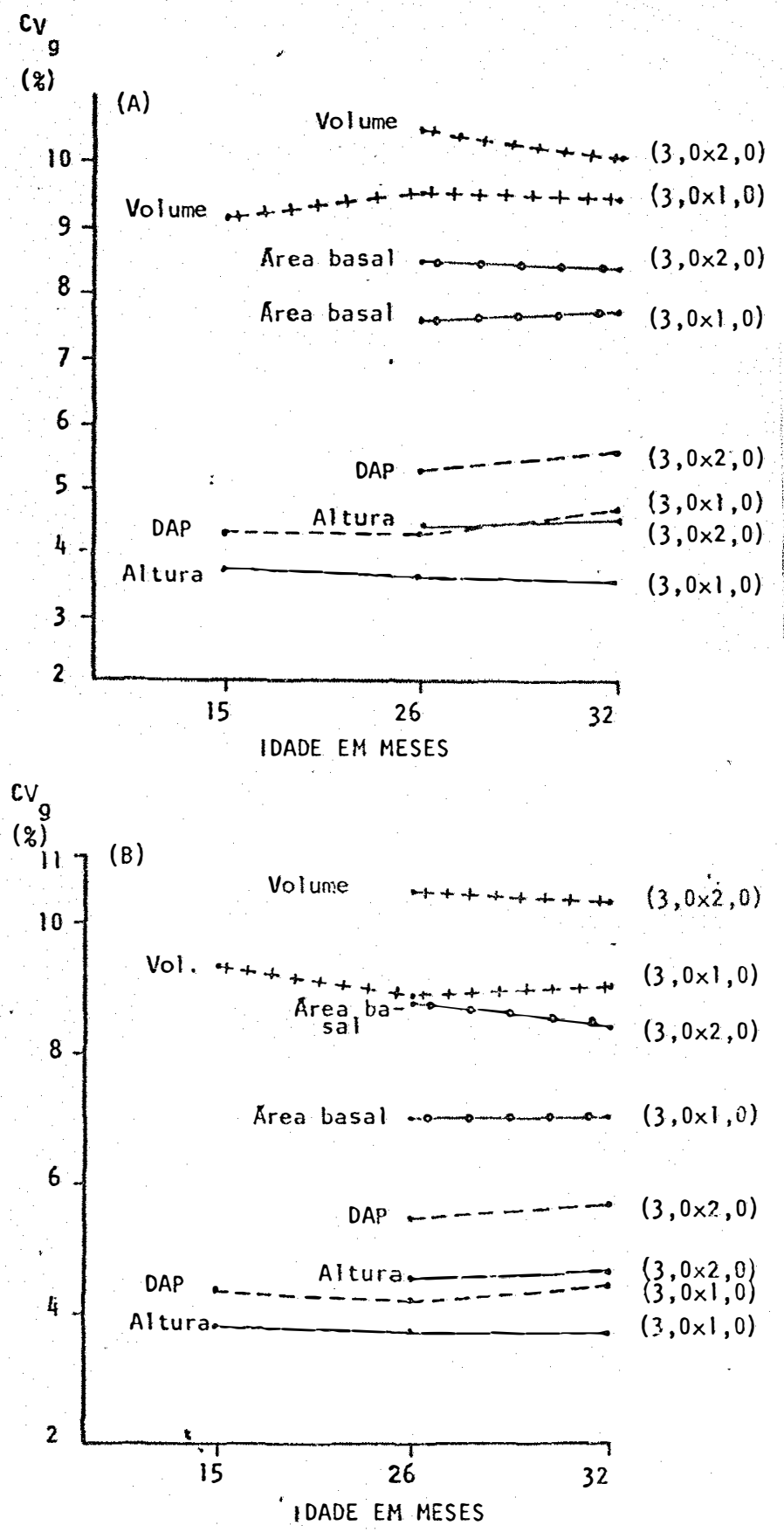

Figura 9 - Evolução dos coeficientes de variação da variância genética $\left(\mathrm{CV}_{\mathrm{g}}\right)$ em função da idade e dos espaçamentos avaliados, para as características de altura, diâmetro (DAP), área basal e volume cilíndrico, para os delineamentos em blocos ao acaso (A) e lätice (B). 

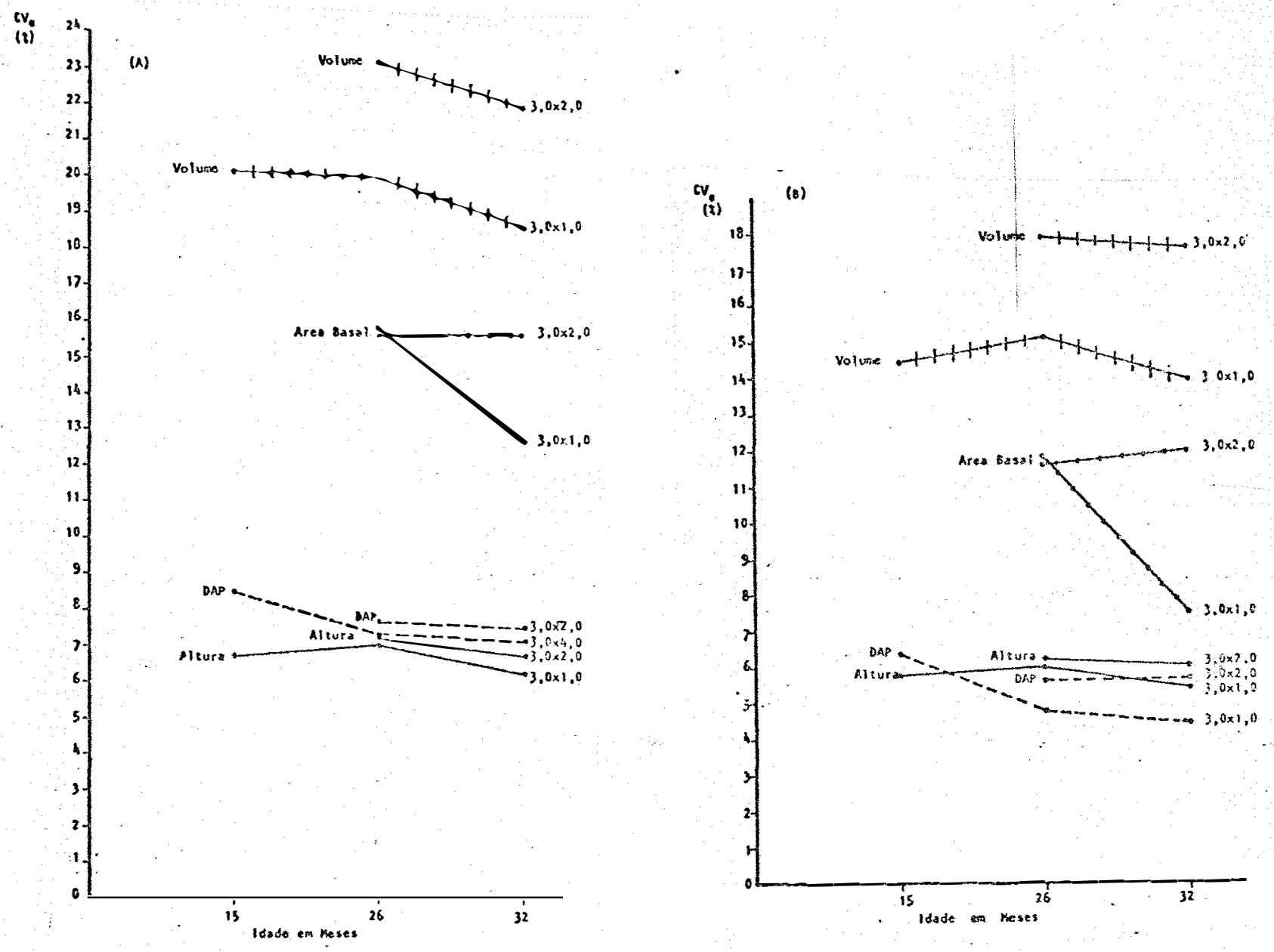

Figura 10 - Evolução do coeficiente de variação para a variância do erro $\left(\mathrm{CV}_{e}\right)$ em função dos esraçamentos testaảos nas três idades avaliadas, considerando os delineamentos em blocos ao acaso (A) e em lätice (B). 
de parcelas apresentou uma tendência generalizada de aumentar com a idade, tanto nos dois espaçamentos testados quanto nos dais delineamentos utilizados. Isso pode ser melhor observado na Figura 11.

Esse incrementc dos coeficientes de variação da variância dentro de parcelas somada as outras variâncias do erro e genética entre progênies incrementou a variância fenotîpica que por sua vez influiu nos valores decrescentes da herdabilidade em função da idade.

0 incremento abrupto do coeficiente de varia ção dentro para a área basal, no espaçamento $3,0 \times 1,0 \mathrm{~m}$, entre as idades de 26 e 32 meses, refletiu-se proporcionalmente na diminuição da herdabilidade dessa característica de 0,122 para 0,082 nesse período.

Esses fatos poderiam ser explicados, considerando a resposta de Eucalyptus saligna Smith à competição en tre as plantas, e ao fato apontacio por FRANKLIN (1979) de que, conforme a competição entre as plantas aumenta, o coeficiente de herdabilidade diminui, o que seria explicado pelo maior a mento da variância dentro de parcelas em ambos os espaçamen tos, sendo mais flagrante no $3,0 \times 1,0 \mathrm{~m}$.

Para os delineamentos em blocos ao acaso e em lätice, os coeficientes de varição dentro de parcelas são os mesmos, já que esses coeficientes são obtidos a partir da variância dentro de parcelas, parâmetro que ë comum para ambos os delineamentos. 


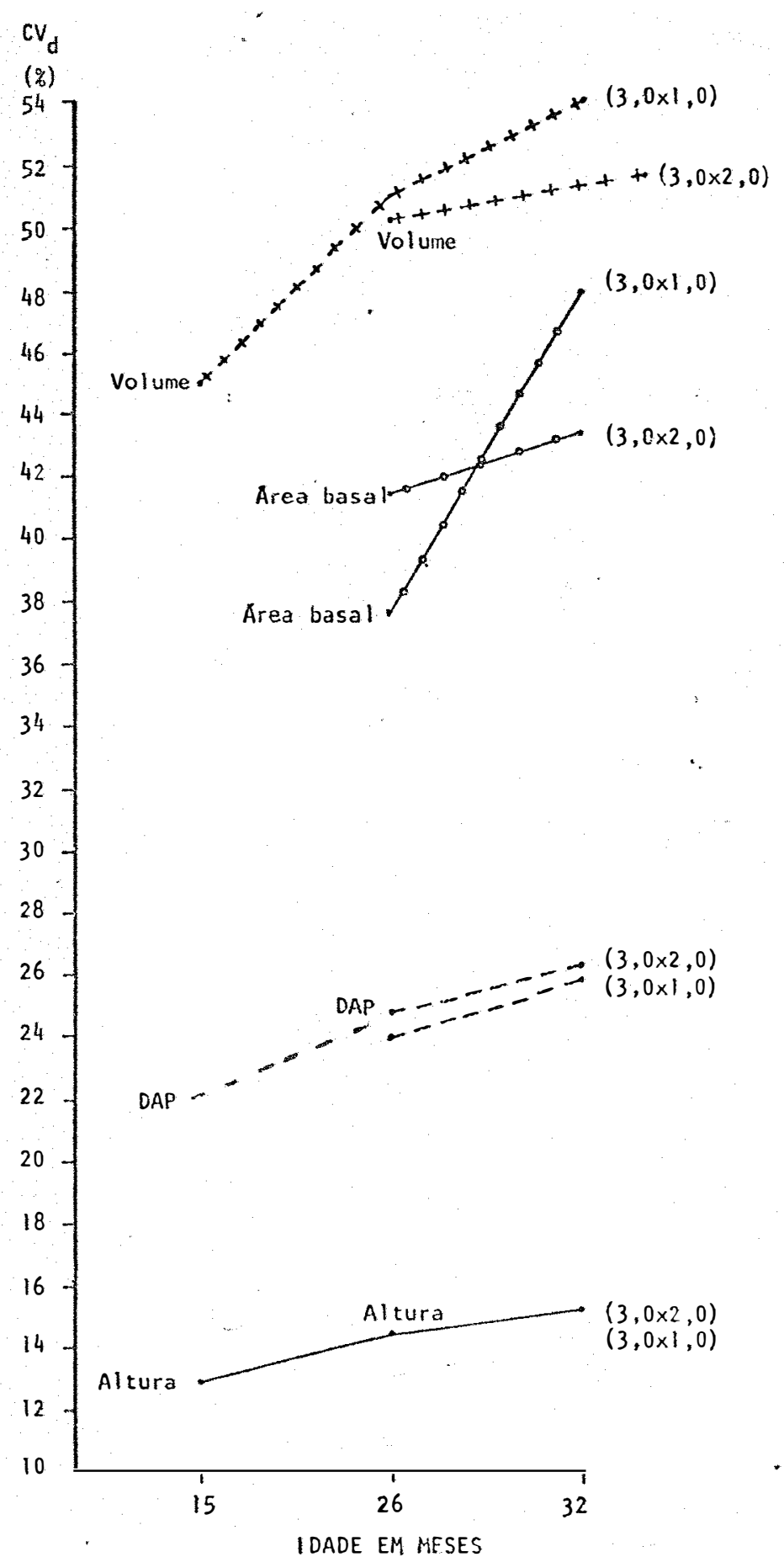

Figura 11 - Evolução do coeficiente de variação da variância dentro de parcelas $\left(\mathrm{CV}_{\mathrm{d}}\right)$ em função à idade e aos espaçamentos para as características de crescimento estudadas. 
O coeficiente de variação da variância fenotípica, para as características de crescimento estudadas, aumen tou com a idade em ambos os espaçamentos, fato que foi verifi cado nos dois delineamentcs utilizados. Quando comparados os valores obtidos nos dois delineamentos percebeu-se que foram sempre maiores no delineamento em blocos ao acaso do que o láa tice, quando comparadas as mesmas características e idades. Na Figura 12 pode ser melhor visualizado esse comportamento.

Esse comportamento dos coeficientes de variação da variânıia fenotípica, podem ser explicados considerando-se o comportamento dos coeficientes de variação da variância dentro de parcelas que fcram muito semelhante daqueles apresentados pelos coeficientes de variação de variância fenotipica e que se incrementaram da mesma forma com a idade.

E importante ressaltar que o maior coeficirnte de variação dentro, que influiu notadamente no comportamen to da herdabilidade das progênies, pode ter sido originado pe la competi்ção dentro das parcelas, o qual foi maior no espaça mento $3,0 \times 1,0 \mathrm{~m}$, deturpando mais notadamente a expressão da herdabilidade nesse espaçamento.

Para o caso da forma do tronco das árvores, os coeficientes de variação da variância dentro de parcelas, da variârcia do erro e da variância fenotípica apresentaram-se se melhantes nos dois espaçamentos, enquanto que o coeficiente de variação para a variância entre progênies apresentou uma dife rença flagrante entre os dois espaçamentos considerados, sen- 


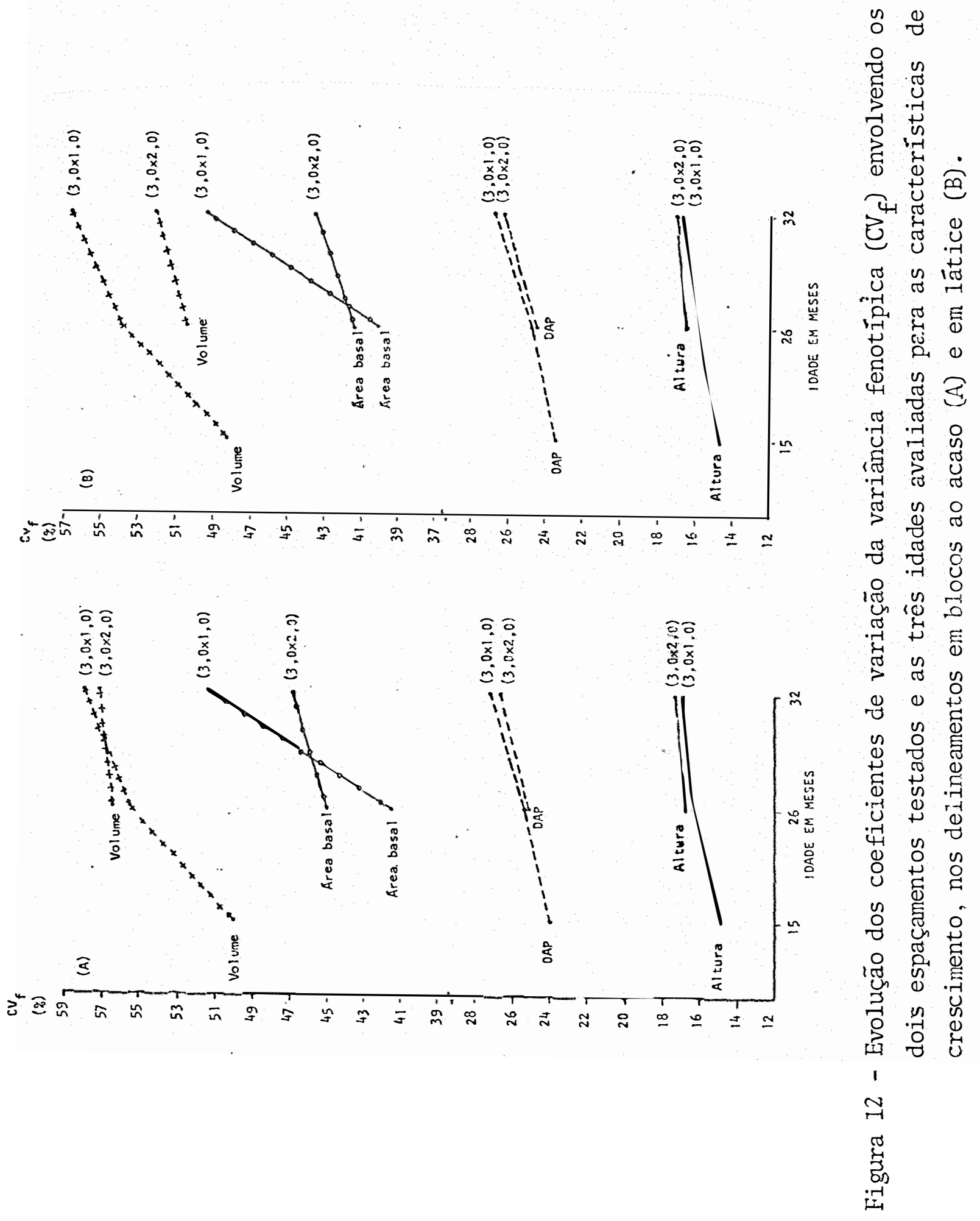


do maior no $3,0 \times 2,0 \mathrm{~m}$. Esse comportamento reflete a diferen ça existente para os valores da variância entre progênies e consequentemente para a variância genética aditiva apresentada em ambos os espaçamentos.

$\mathrm{Na}$ Tabela 21 , podem ser observadas as estimati vas dos coeficientes de herdabilidade e de variação genética e não genética para as características de altura, diâmetro (DAP), área basal e volume cilindrico, nas idades de 26 e 32 meses, obtidos nas análises da variância conjuntas.

Para as análises conjuntas envolvendo os dois espaçamentos para cada uma das idades de 26 e 32 meses, os coe ficientes de herdabilidade apresentaram-se como intermediarios entre aqueles obtidos para cada uma das características nas análises individuais para os dois espaçamentos na iajade considerada, exceto para o volume silindrico e ärea basal nas idades de 32 e 26 meses, respectivamente.

Para altura de plantas, à idarje de 26 meses, ob teve-se na anâlise conjunta um valor para a herdabilidada de 0,28 , enquanto que nas anâlises individuais a essa mesma idade, para os espaçamentos $3,0 \times 1,0 \mathrm{~m}$ e $3,0 \times 2,0 \mathrm{~m}$, os valores para a herdabilidade foram de 0,21 e 0,31 , respectivamente. E importante salientar que os coeficientes de.herdabilida de foram sempre mais próximos daqueles obtidos nas anäiises ındividuais para o espaçamento mais amplo.

Para o volume à idade de 32 meses e ârea basal à idade de 26 meses, os valores da herdabilidade foram i- 
Tabela 21 - Estimativas de coeficientes de herdabilidade e de coeficientes de variação genética e não genética para as características estuxladas, obtidas nas análises conjuntas para espaça mentos nas idades de 26 e 32 meses.

\begin{tabular}{|c|c|c|c|}
\hline \multirow[t]{2}{*}{ Característica } & \multirow[t]{2}{*}{ Parânetros } & \multicolumn{2}{|c|}{ Idades } \\
\hline & & 26 meses & 32 meses \\
\hline \multirow[t]{2}{*}{ Altura (m) } & $\begin{array}{l}\mathrm{h}^{2} \\
\mathrm{CV}_{\mathrm{g}} \\
\mathrm{CV} \\
\mathrm{CV} \\
\mathrm{CV}_{\mathrm{e}} \\
\mathrm{CV}_{\mathrm{f}}\end{array}$ & $\begin{array}{r}0,28 \\
4,35 \\
14,43 \\
6,28 \\
16,33 \\
14,88\end{array}$ & $\begin{array}{r}0,28 \\
4,46 \\
15,16 \\
5,92 \\
16,88 \\
15,10\end{array}$ \\
\hline & Média & 9,98 & 10,62 \\
\hline Diâmetro $(\mathrm{cm})$ & $\begin{array}{l}\mathrm{h}^{2} \\
\mathrm{CV} \\
\mathrm{CV} \\
\mathrm{CV} \\
\mathrm{CV} \\
\mathrm{CV} \\
\mathrm{CV} \\
\mathrm{exp}\end{array}$ & $\begin{array}{r}0,16 \\
5,01 \\
23,65 \\
5,86 \\
24,87 \\
17,81\end{array}$ & $\begin{array}{r}0,16 \\
5,36 \\
25,32 \\
5,90 \\
26,54 \\
18,97\end{array}$ \\
\hline$\therefore$ & Mëdia & 6,86 & 7,65 \\
\hline \multirow[t]{2}{*}{ Area basal (m³/ärvore) } & $\begin{array}{l}\mathrm{h}^{2} \\
\mathrm{CV}_{\mathrm{g}} \\
\mathrm{C} V_{\mathrm{d}} \\
\mathrm{CV} \mathrm{e} \\
\mathrm{CV}_{\mathrm{f}} \\
\mathrm{CV}_{\mathrm{exp}}\end{array}$ & $\begin{array}{r}0,16 \\
8,34 \\
39,74 \\
12,94 \\
42,61 \\
30,93\end{array}$ & $\begin{array}{r}0,13 \\
8,57 \\
45,54 \\
11,64 \\
47,78 \\
32,10\end{array}$ \\
\hline & Média & 0,00394 & 0,00494 \\
\hline \multirow[t]{2}{*}{ Volume ( $\mathrm{m}^{3} /$ arrvore) } & $\begin{array}{l}\mathrm{h}^{2} \\
\mathrm{CV}_{\mathrm{g}} \\
\mathrm{CV} \\
\mathrm{CV} \\
\mathrm{CV}_{\mathrm{f}} \\
\mathrm{CV}_{\mathrm{exp}}\end{array}$ & $\begin{array}{r}u, 13 \\
10,89 \\
50,65 \\
17,67 \\
54,74 \\
40,47\end{array}$ & $\begin{array}{r}0,14 \\
10,76 \\
52,78 \\
17,51 \\
56,64 \\
40,58\end{array}$ \\
\hline & Média & 0,0419 & 0,0561 \\
\hline \multirow[t]{2}{*}{ Forma do tronco (notas) } & $\begin{array}{l}\mathrm{h}^{2} \\
\mathrm{CV}_{\mathrm{g}} \\
\mathrm{CV} \\
\mathrm{CV}_{\mathrm{e}} \\
\mathrm{CV}_{\mathrm{f}} \\
\mathrm{CV}_{\exp }\end{array}$ & $\begin{array}{l}- \\
- \\
- \\
-\end{array}$ & $\begin{array}{r}0,31 \\
5,77 \\
18,66 \\
7,19 \\
20,89 \\
10,22\end{array}$ \\
\hline & Média & - & 3,59 \\
\hline
\end{tabular}

$\mathrm{h}^{2}=$ coefiriente de herdabilidade sentido restrito; $\mathrm{Cl}_{\mathrm{o}}=$ coeficiente de variação genética; $\mathrm{CV}_{\mathrm{d}}=$ coeficiente de variaçāo dentrô de parcelas; $\mathrm{CV}_{\mathrm{e}}$ = coeficiente de variação da variäncia do erro; $\mathrm{CV}_{f}=$ coeficiente de variação fenotípica; $C_{\text {exp }}$ = coeficiente de variação experimental. 
guais do que os correspondentes valores nas análises individuais para a mesma idade.

Os coeficientes de herdabilidade praticamente não se alteraram da idade de 26 para a de 32 meses, não mostrando nenhuma tendência clara. A pequena diferença entre as idades, provavelmente, não permitiu essa detecção.

Na Figura 13 pode ser melhor observada a evolu ção desses coeficientes de herdabilidade envolvendo os espaça mentos testados e em função da idade.

A pequena queda no valor da herdabilidade com a idade apresentada pela característica área basal pode ser ex plicada pelo comportamento, nesse período, do coeficiente de variação da variância dentro de parcelas, o qual apresentou um incremento considerável dos 26 para os 32 meses de idade. Esse comportamento refletiu, em consequência, no incremento ua variância dentro de parcelas e, na mesma proporção, no incremento da variância fenotípica.

Os coeficientes de variação estimados a partir das anälises conjuntas, quando comparados com os respecti vos coeficientes obtidos a partir das anâlises da variância in dividuais, mostraram uma tendência de acompanhar a evolução daqueles coeficientes de variação ao espaçamento $3 ; 0 \times 2,0 \mathrm{~m}$. Esse comportamento foi verificado para todos os coeficientes de variação estimados, para as características de crescimento, exceto área basal. Para esta característica os coeficien tes de variação genëtica e da variância do erro apresentaram um 
.155 .

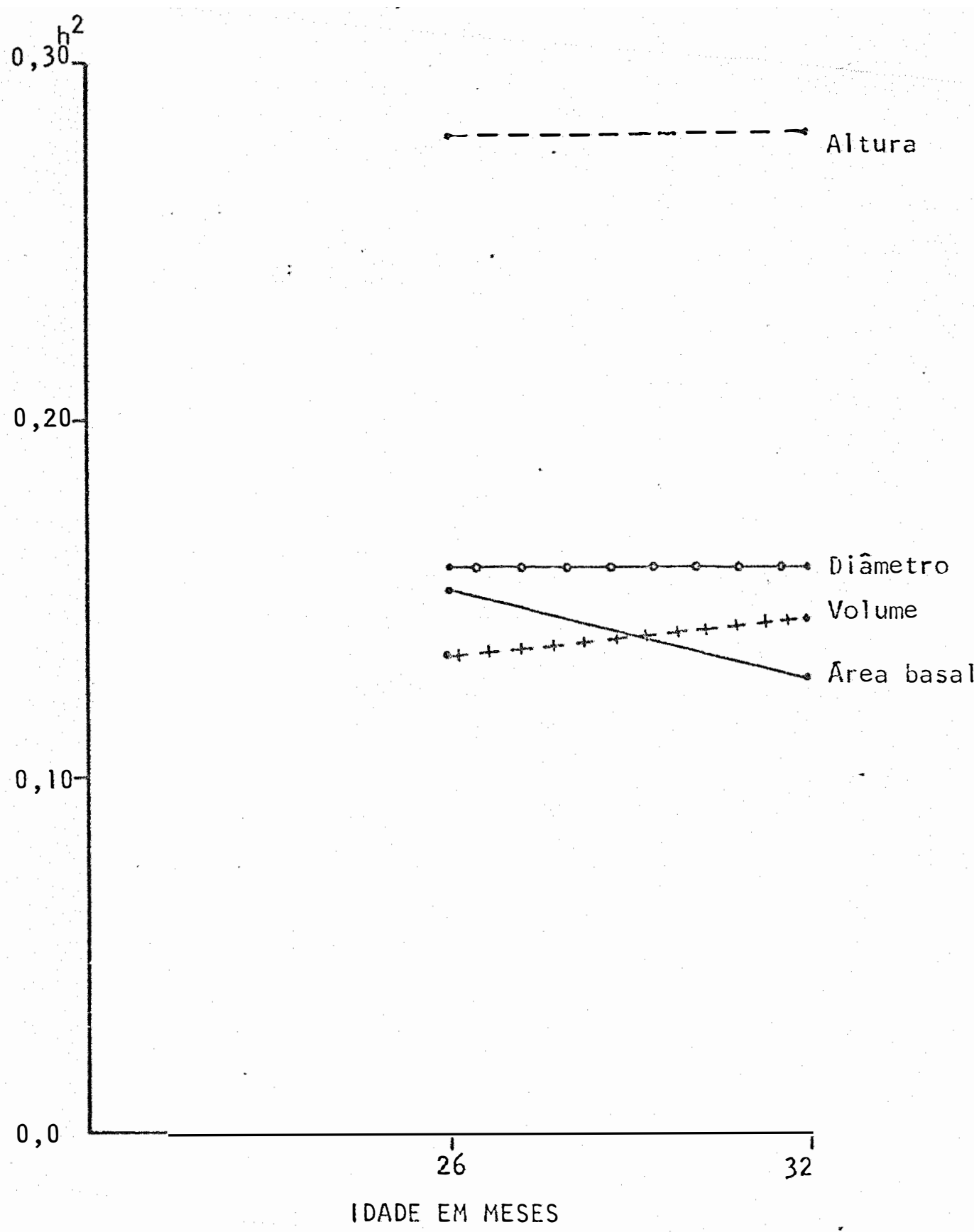

Figura 13 - Evolução dos coeficientes de nerdabilidade nas análises da variância conjuntas, envolvendo os dois espaçamentos testa dos, nas idades de 26 e 32 meses. 
comportamento na análise conjunta inverso do apresentado pelas análises individuais, auméntando e diminuindo com a idade, respectivamente.

Na Figura 14, pode-se observar a evolução dos coeficientes de variação genéticas e não genéticas, estimadas a partir das análises da variância conjuntas, para as duas idades consideradas.

Para a forma do tronco das árvores, caracterís tica avaliada aos 32 meses de idade, os coeficientes de varia ção genéticas e não genêticas apresentaram-se muito semelhantes aos obtidos na análise da variância individual do espaçamento $3,0 \times 2,0 \mathrm{~m}$, refletindo assim a maior influência do espaçamento mais amplo no desenvolvimento das progênies, quanto a forma do tronco.

A herdabilidade ao nível de plantas, obtida a partir da análise conjunta envolvendo os dois espaçamentos, va riou com as características consideradas, apresentando maiores valores para a altura, vindo a seguir o diâmetro, ā ärea basal e o volume. Para as idades de 26 e 32 meses, os coeficientes de herdabilidade para a área basal e o volume cilíndrico tiveram uma inversão quanto a seu valor relativo.

0 fato de terem sido verificados praticamente os mesmos valores de herdabilidade para altura, diâmetro e vo lume cilíndrico nas análises da variância conjuntas, nas idades de 26 e 32 meses, mostra que a seleção das progênies para essas caracteristicas pode ser feita indistintamente em qual- 

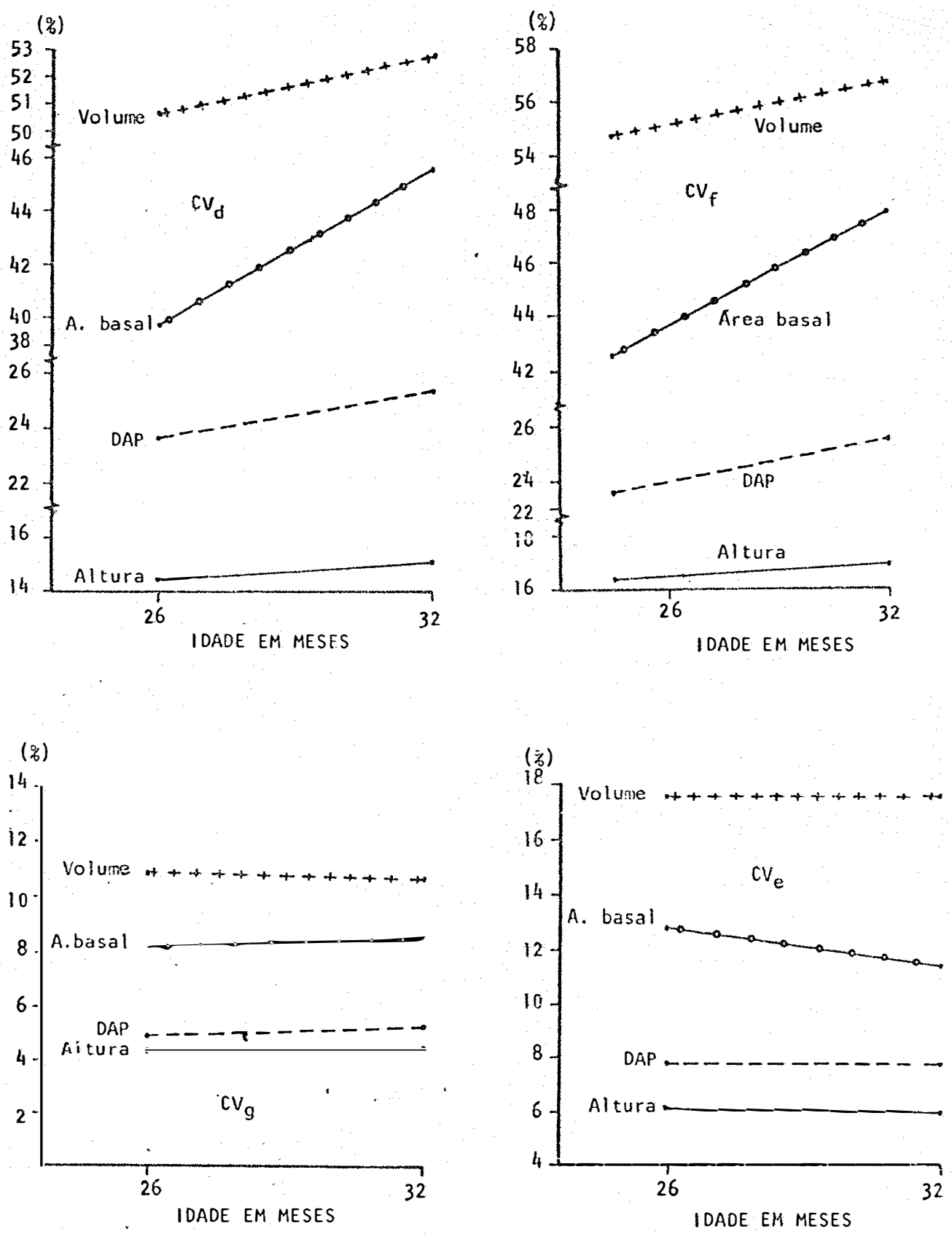

Figura 14 - Evolução dos coeficientes de variação genética e näo genética nas anālises da variância conjuntas, envolvendo os dois espaçamentos testados, entre as idades de 26 e 32 meses. 
quer uma das duas idades consideradas.

A herdabjlídade para forma do tronco das ärvores à idade de 32 meses, apresentou-se intermediária entre aqueles valores obtidos para os espaçamentos nas análises indi viduais e, apresentando, à semelhança das características de crescimento, um valor mais próximo do valor obtido para o espaçamento $3,0 \times 2,0 \mathrm{~m}$, mostrando, a maior influência desse e paçamento sobre a característica avaliada.

\subsection{RELAÇÕES ENTRE COEFICIENTES DE VARIAÇÃO GENETIICA E EX PERIMENTAL, E ENTRE AS VARIÂNCIAS DENTRO E ENTRE PRO- GÊNIES, E ENTRE AS VARIÂNCIAS DENTRO E AMBIENTAL}

A relação entre o coeficiente de variação genê tica e experimental é, segundo VENCOVSKY (1978), um importante indicador das possibilidades de sucesso na obtenção de ganhos genéticos atravês da seleçũo, mostrando que a situação é favorável para a obtenção de ganhos, em milho, quando os valo res dessa relação tendem a se aproximar de 1,0 ou mais. Muitos autores (KAGEYAMA, 1980; PIRES, 1984; PINTO JR., 1984), têm utilizado essa relação em espécies florestais para identificar a condição mais favorável para a seleção dentro dos ensaios.

Considerando-se os valores encontrados, e que podem ser observados na Tabela 22 , a condição mais favorável 
para a seleção dentro do ensaio seria para altura de plantas seguida pelo volume cilindrico, considerando-se a idade de 15 meses e o espaçamento $3,0 \times 1,0 \mathrm{~m}$, tanto em lätice como em blo cos ao acaso. Essa afirmativa pode ser confirmada considerando-se os respectivos valores do erro experimental que foram menores nesses casos, assim como os coeficientes de herdabilida de obtidos.

Considerando-se que a relação entre as variâncias se apresenta como um parâmetro indicador da estrutura ge nética das populações, segundo Crow e Kimura, 1970; Allard, 1971; Lindgreen, 1976 e Falconer, 1981, todos eles citados por PIRES (1984), tendo em vista a influência dos níveis de cruza mentos sobre as variânias genêticas entre e dentro de famí lias e, consequentemente, sobre a variância fenotipica total.

FONSECA (1982) sugeriu a relação entre a váriância dentro de progênies e a variância genêtica ertre progênies, para altura das plantas como um indicador do sistema reproriutivo, argumentando que nas plantas alógamas essa reiação tenderia sempre para valores maiores do que dez, desde que a população não apresenta restrições na sua base genética.

Por sua vez, PIRES (1984) sálienta que a relação entre a variância dentro e a variância ambiental entre par celas $\left(\sigma^{2} \mathrm{~d} / \sigma^{2} \mathrm{e}\right)$, para as características de crescimento, nure ce proporcionar informação reilativamente segura sobre o siste ma reprodutivo e a base genética da população em todas as cị cunstâncias. Isso se deve, continua o autor, porque tal rela- 


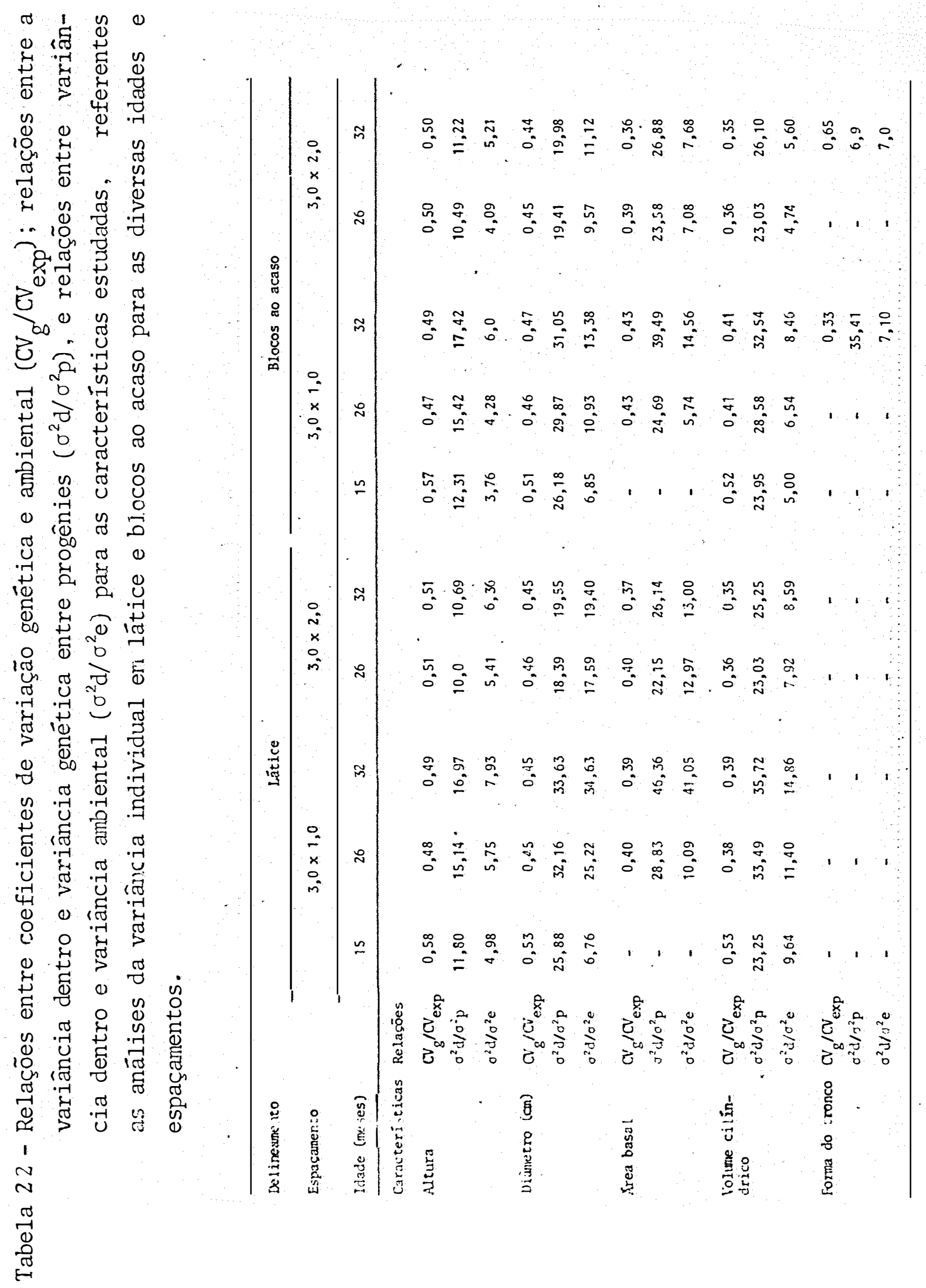


çãc é formada por um componente genético $\left(\sigma^{2} \mathrm{dg} / \sigma^{2}\right.$ e) que é fumção do sistema de cruzamonto e um componente ambiental entre plantas $\left(\sigma^{2} \mathrm{de} / \sigma^{2} \mathrm{e}\right)$, que guarda uma proporção com a variância ambiental entre parcelas $\left(\sigma^{2} \mathrm{~d} / \sigma^{2} \mathrm{e}=\left(\sigma^{2} \mathrm{~d} q+\sigma^{2} \mathrm{de}\right) / \sigma^{2} \mathrm{e}\right)$. Final mente PIRES ressalta que para espaçamentos quadrados, em espẹ cies alógamas de base genética restrita, como também em espécies autógamas, a relação deverā ser $\sigma^{2} \mathrm{~d} / \sigma^{2} \mathrm{e}=\sigma^{2} \mathrm{de} / \sigma^{2} \mathrm{e}$ apresentando valores iguais ou próximos de um, enquanto em espécies alógamas de base genética adequada a relação $\sigma^{2} d / \sigma^{2}$ e deverá apresentar valores mais elevados, devido a presença da yariância genética dentro $\left(\sigma^{2} \mathrm{~d} g\right)$.

As relações entre as variâncias dentro e entre progênies $\left(\sigma^{2} \mathrm{~d} / \sigma^{2} \mathrm{p}\right)$ apresentaram valores variāveis entre os espaçamentos face a idade sendo iudos eles superiores a 10 , ou seja que us dados obtidos apresentam a mesma tendência daque les observados para plantas alógamas.

E importante salientar o fato de que, no decor rente estudo, as relações entre a variância dentro e a variân cia entre progênies apresentaram valores para as caracteristi cas de ärea basal e volume cilindrico, sempre maiores do que 20, e para o diâmetro valores acima de 20 no espaçamento 3,0 x $1,0 \mathrm{~m}$ em ambos os delineamentos, e valores menores a 20 , embo ra, muito próximos a esse valor, para essa característica no espaçamento $3,0 \times 2,0$, ocorrendo ambém em ambos os delineamentos.

Os resultados das relações entre coeficientes de 
variação e variâncias dentro e genética e dentro e ambiental, obtidos a partir das anâlises da variância individuais para as características estudadas podem ser observados na Tabela 22 .

As relações entre a variância dentro e variância ambiental $\left(\sigma^{2} \mathrm{~d} / \sigma^{2} \mathrm{e}\right)$ apresentaram valores variando de 4,09 para altura de plantas no espaçamento $3,0 \times 1,0 \mathrm{~m}$, em blocos ao acaso, a 41,05 para área basal no mesmo espraçamento, e no delineamento em lảtice.

Os valores obtidos para as relaçōes entre a va riância dentro de progênies e entre progênies, e dentro de pro gênies e ambiental, confirmam que o Eucalyptus saligna Smith de Itatinga apresenta características próprias de alogamia.

\subsection{COEFICIENTES DE CORRELAÇÃO GENËTICA E FENOTÍPICA EN- TRE AS CARACTERÍSTICAS DE ALTURA, DIÂMETRO E VOLUME CILINDRICO PARA OS DOIS ESPAÇAMENTOS TESTADOS, NAS I DADES DE 26 E 32 MESES}

As correlações genéticas aditivas $\left(\mathrm{r}_{\mathrm{A}}\right)$ ao nível de plantas e as correlações fenotípicas $\left(\mathrm{r}_{\mathrm{F}}\right)$ ăo nível de mécias de famílias entre as características altura de plantas, diâmetro (DAP) e volume cilindrico, estimadas para os dois espaçamentos testados, são mostradas na Tabela 23. 


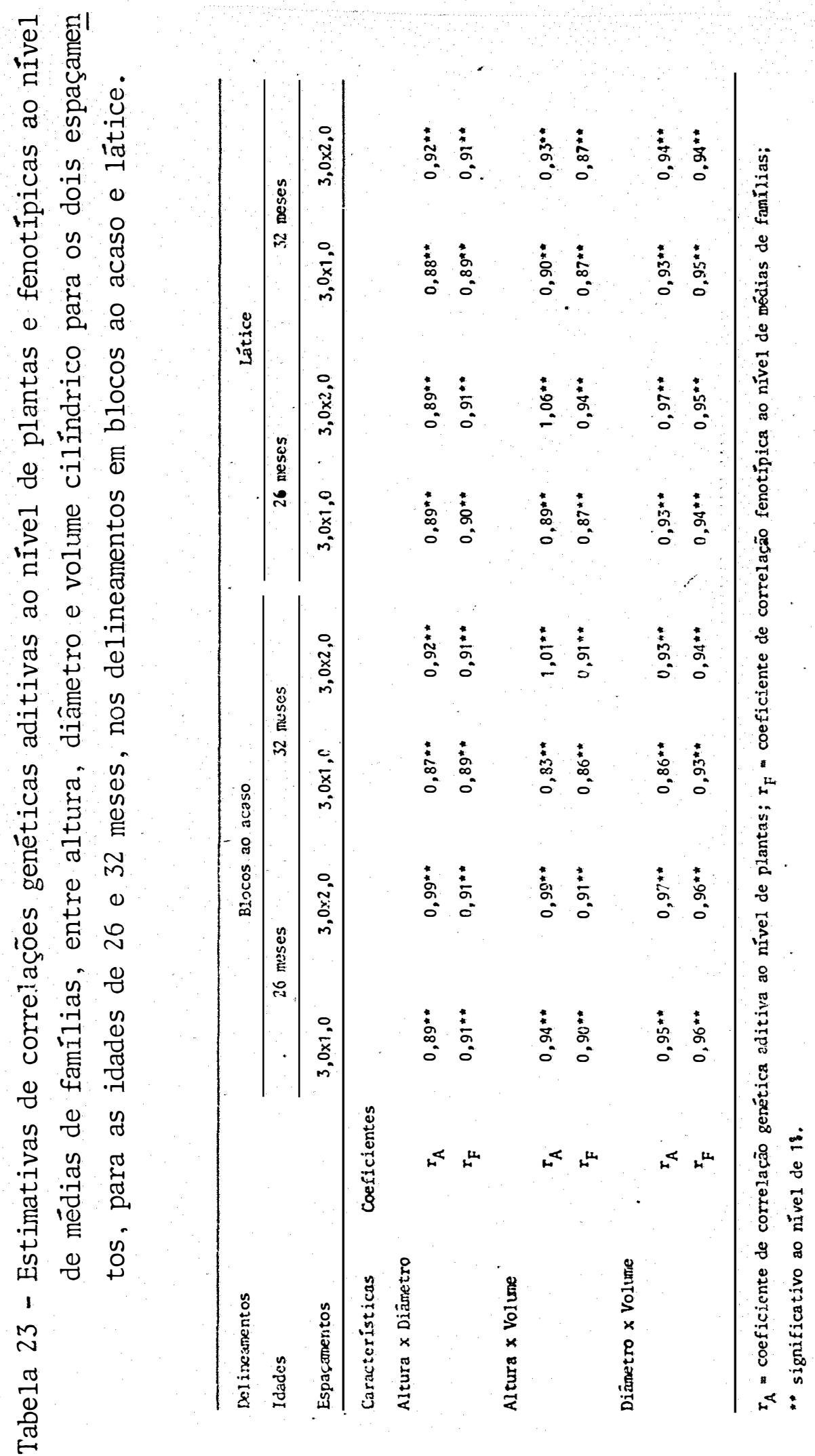


As estimativas obtidas de correlações genéticas aditivas ao nível de plantas individuais apresentaram vaIores altos de correlação, mostrando em geral o reflexo de uma característica sobre a outra quando se pratica a seleção para uma delas. Essas correlações altas e positivas são coerentes com os resultados obtidos por grande número de autores em diferentes espécies florestais, destacando-se os trabalhos desenvolvidos por VAN WYK (1976), KAGEYAMA (1980), KAGEYAMA (1983), PINTO JR. (1984), entre outros.

As estimativas de correlações fenotípicas ao nível de médias de famílias mostraram a mesma tendência que as correlações genéticas aditivas e valores muito semelhantes em ambos os delineamentos, mostrando, pouca interferência ambien tal na mudança dos dois tipos de correlações estudados.

As estimativas de correlações genéticas e feno típicas não só diferiram substancialmente entre si, como apre sentaran uma tendência semelhante nara os espaçamentos e, ain da para os dois delineamentos utilizados.

A altura de plantas mostrou altas correlações genéticas aditivas e fenotípicas com o diâmetro e volume. Esse fato é da maior importância para definir uma estratégía de seleção, já que as características de altura e diâmetro, como salientado por KAGEYAMA (1980), são mais făceis de se medir e a sua mensuração pode ser feita com major precisão.

Considerando-se que a área basal é função dire ta do diâmetro; e que consequentemente as correlações dessas 
características seriam muito semlhantes; optou-se por fazer correlações, tanto genéticas como fenotípicas somente para o diâmetro.

0 volume cilíndrico, característica que é com. posta da altura e diâmetro e é grandemente influenciada pela sobrevivência, mostrou-se altamente correlacionado com a altu ra e o diâmetro.

Segundo KAGEYAMA (1980), quando atribuído maior peso na seleção a características altamente correlacionadas, a seleção de uma resultarả em avanços significativos, também, na outra característica. Portanto, o conhecimenco do grau de associação entre características, do ponto de vista genético, se constitui numa excelente ferramenta para o planejamento das estratégias a serem utilizadas num programa de melhoramento.

FALCONER (1983) salientou o fato de que a exis tência de alta correlação fenotípica entre características de baixa herdabilidade reflete, em suss expressões, as influên cias do ambiente.

As correlações genéticas e fenotípicas entre ambientes para um espaçamento para as características altura das plantas, diâmetro, área basal e volume cilíndrico são nos tradas na Tabela 24 .

As correlações genéticas aditivas entre espaça mentos para as duas idades revelaram valores muito altos e pró ximos a unidade, com valores maiore, para 32 meses do que para 26 meses de idade. Essas correlações genéticas aditivas en 
Tabela 24 - Correlações gené icas e fenotípicas entre espaçanentos para uma idade, e entre idades para um espaçamento.

Idades Espaçamentos Altura Diâmetro Area basal Volume

$32(3,0 \times 1,0)(3,0 \times 2,0)$

$\begin{array}{lllll}\mathrm{r}_{\mathrm{A}} & 0,99^{* *} & 0,92^{* *} & 0,91^{* *} & 0,95^{* *} \\ \mathrm{r}_{\mathrm{F}} & 0,66^{* *} & 0,56^{* *} & 0,51^{* *} & 0,53^{* *}\end{array}$

$26 \quad(3,0 \times 1,0)(3,0 \times 2,0)$

$\begin{array}{lllll}{ }^{r_{A}} & 0,89^{* *} & 0,82^{* *} & 0,80^{* *} & 0,89^{* *} \\ \mathrm{r}_{\mathrm{F}} & 0,60^{* *} & 0,51^{* *} & 0,48^{* *} & 0,52^{* *}\end{array}$

26 e 32

$(3,0 \times 1,0)$

$\begin{array}{lllll}\mathrm{r}_{\mathrm{A}} & 0,99^{* *} & 0,99^{* *} & 0,99^{* *} & 0,99^{* *} \\ \mathrm{r}_{\mathrm{F}} & 0,95^{* *} & 0,97^{* *} & 0,97^{* *} & 0,98^{* *}\end{array}$

26 e 32

$(3,0 \times 2,0)$

$\begin{array}{lllll}\mathrm{r}_{\mathrm{A}} & 0,99^{*} & 0,99^{* *} & 0,98^{* *} & 0,98^{* *} \\ \mathrm{r}_{\mathrm{F}} & 0,96^{* *} & 0,98^{* *} & 0,97^{* *} & 0,97^{* *}\end{array}$

$\mathrm{r}_{\mathrm{A}}=$ coeficiente de correlação genética ao nível de plantas; $\mathrm{r}_{\mathrm{F}}=$ coeficiente de correlação fenotípica ao nível de famílias; * significativo ao nível de $1 \%$. 
tre idades foram igualmente próximas a unidade nos dois espaçamentos estudados.

Por outro lado, as correlações fenotípicas ao nível de médias de famílias mostraram valores bem mais baixos entre espaçamentos, nas duas idades estudadas, o que revelaria o efeito ambiental quando a associação é entre plantas de ambientes (parcelas) diferentes. Para as correlações fenotípi cas entre idades, os valores foram muito próximos às correla ções genéticas, ou um pequeno efeito ambiental.

BURDON (1977) relata que as correlações genét cas geralmente têm sido estimadas quando ambas as características foram avaliadas sobre a mesma planta. Essas correlações segundo o autor são denominadas de correlações genéticas tipo A; qußndo duas características são avaliadas sobre indivíduos diferentes dentro das entidades genéticas sob estudo, origina-se um caso especial de correlação genética ent:e ambientes, a qual o autor denominou como sendo correlações gené ticas tipo B.

O conceito de correlações genéticas entre ambientes apresenta, segundo BURDON (1977), grardes vantagens para a pesquisa, jā que essa correlação é direcionada para se conhecer o papel dos ambientes na geração das interações com o material genético sob estudo. Esse conceito alternativo para o estudo das interações deriva do comportamento observado para o material genético em cada um dos ambientes, sendo considerados como características diferentes. Assim sendo, esse 
comportamento relativo dos genótipos para taxa de crescimer. to, por exemplo, em dois ambientes diferentes pode ser expres so como sendo a correlação genêtica entre as suas taxas de crescimento em cada desses dois ambientes. 


\section{CONCLUSÕES}

Os resultados obtidos no presente trabalho per mitiram as seguintes conclusões:

- O crescimento e sobrevivência das plantas dos ensaios foram considerados bons, confirmando o potencial da espécie para essas condições. 0 crescimento no espaçamento $3,0 \times 2,0 \mathrm{~m}$ foi maior do que no $3,0 \times 1,0 \mathrm{~m}$ para todas as características.

- A densidade básica da madeira mostrou um valor mëdio bastante expressivo para a idade de 17 meses $(0,411$ $\left.\mathrm{g} / \mathrm{cm}^{3}\right)$. Ainda que a variação para essa característica ao nível de mêdias de progênies, tenha sido baixa, foram encontra das progênies com valores bastante expressivos para sua dens $\underline{i}$ dade. 
- Ao nível das anâlises individuais foram detectadas variações genéticás significativas entre progênies, para todas as características de crescimento estudadas em todas as idades e espaçamentos avaliados. Essas variações genéticas detectadas mostraram uma certa homogeneidade entre espa çamentos e entre idades dentro dos espaçamentos.

- Para sobrevivência das plartas entre as progênies sob estudo, somente foram verificadas variações genét cas no espaçamento $3,0 \times 1,0 \mathrm{~m}$. Contrariamente, para forma do tronco essas variações só existiram no espaçamento $3,0 \times 2,0 \mathrm{~m}$. 0 menor espaçamento aumentou as variações entre progênies quan to a sobrevivência e, por outro lado, mascarou as diferenças pa ra a forma do tronco.

- Os dois delineamentos utilizados no presen te caso, Látice e blocos ao acaso, foram igualmente eficicn tes para avaliar os testes de progênies, quando considerados os valores de F obtidos.

- As anâlises da variância conjuntas envolvendo os dois espaçamentos, revelaram variações genéticas entre progênies para todas as características e idades consideradas. O efeito do espaçamento teve um aumento expressivo dos 26 para os 32 meses de idade em todas as características, exceto para altura. A interação progênies $x$ espaçamentos reve- 
lou-se nao significativa para todas as características e idades estudadas.

- O desdobramento da interação de progênies $x$ espaçamentos revelou maior expressividade para variação entre progênies dentro do espaçamento $3,0 \times 2,0 \mathrm{~m}$, do que no espaça mento menor, principalmente para volume cilíndrico, o que sugere a presença de interação progênies $x$ espaçamento.

- Os coeficientes de correlação de Spearman, aplicados as médias das progênies entre espaçamentos, mostra ram uma não concordância nas posições relativas das progênjes nos dois espaçamentos, sendo mais acentuada para forma do tron co, reforçando a existência de algum tipo de interação. Esse fato tem grande influência na seleçäo das melhores progênies para os dois espaçamentos, não havendo coincidência das progê nies.

- Analisando-se o crescimento diferencial das progênies em função do espaçamento, foi possível definir três tipos de comportamento das progênies: progênies que se desenvolveram melhor nos espaçamentos $3,0 \times 1,0$ e $3,0 \times \cdot 2,0 \mathrm{~m}$, e progênies que se desenvolveram igualmente em ambos os espaçamentos.

- Os coeficientes de variação genética e não 
genética mostraram tendências diversas para as diferentes com ponentes: os coeficientes de variação genética e ambiental per maneceram quase que constantes dos 15 para os 32 meses de idade. O coeficiente de variação dentro de progênies, e em con sequência o coeficiente de variação fenotípica, apresentaram uma tendência para aumentar com:a idade.

- As estimativas de herdabilidade, no sentido restrito e ao nível de plantas nas análises da variância in dividuais, tiveram uma diminuição dos 15 para os 26 meses de idade e, permanecendo estáveis até os 32 meses de idade. Esses valores de herdabilidade mostraram a tendência para valores maiores no espaçamento mais amplo do que no mais apertado, sendo muito mais expressiva essa diferença para forma do tronco. Nas anâlises conjuntas observou-se a mesma tendênciá, com valores para as herdabilidades e coeficientes de varia ção genéticos e não genéticos, mais próximos daqueles obtidos para o espaçamento mais amplo, das anảlises individuais.

- Considerando que o espaçamento $3,0 \times 2,0 \mathrm{~m}$ é o mais utilizado atualmente, é importante ressaltar que os va lores de herdabilidade obtidos no mesmo, apresentaram os maio res valores para forma de tronco $(0,45)$, vindo a seguir a aitura $(0,28)$, diâmetro $(0,18)$, área basal $(0,13)$ e volume cjlindrico $(0,13)$. 
- Os valores obtidos para as relações entre a variância dentro de progênies e entre progênies $\left(\sigma^{2} \mathrm{~d} / \sigma^{2} \mathrm{p}\right)$ e dentro de progênies e ambiental $\left(\sigma^{2} \mathrm{~d} / \sigma^{2} \mathrm{e}\right)$ confirmam que o Eucalyptus saligna Smith de Itatinga apresenta características próprias de alogamia. A relação entre os coeficientes de variação genético e experimental $\left(\mathrm{CV}_{\mathrm{g}} / \mathrm{CV}\right.$ exp $)$ apresentaram-se muito estáveis para cada característica, com ligeira vantagem a ida de de 15 meses. Esse coeficiente acompanhou a tendêrcia dos coeficientes de herdabilidade para as características conside radas.

- As correlações genéticas e fenotípicas, entre as características de crescimento (altura, diâmetro e volume cilíndrico), mostraram valores positivos e pröximos a unidade, tanto para os espaçamentos como para as idades estula das, assim como para os dois delineamentos utilizados.

- As correlações genéticas entre espaçamentos para uma idade revelaram valores aitos e positivos, sendo maio res para 32 do que para 26 meses de idade. Essas correlações genëticas aditivas entre idades, foram igualmente próximas à unidade nos dois espaçamentos. As correlações fenotípicas, ao nível de médias de progênies entre espaçamentos, mostraram uma diminuição expressiva para seus valores nas duas idades consideradas, o qual não ocorreu entre idades para um espaçamen to. 
.174 .

\section{LITERATURA CITADA}

ASSIS, T.F. et alii, 1982a. Teste de progênies de Eucalyptus paniculata SM. Silvicultura, São Paulo, $\underline{8}(28): 160-161$.

ASSIS, T.F. et alii, 1982b. Teste de progênies de Eucalyptus cloegiana F. Mue11. Silvicultura, São Paulo, $\underline{8}(28)$ : 158159 .

BALLONI, E.A. et alii, 1980. Estudo comparativo de diferentes tiñs de recipientes para a produção de mudas de Euca

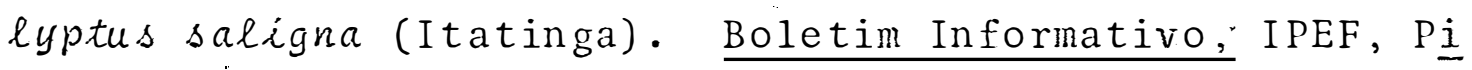
racicaba, $\underline{8}(26): 1-7$. 
BALLONI, E.A. e J.W. SIMŐES, 1980. O espaçamento de plantio e suas implicações silviculturais. Série Técnica. IPEF, Piracicaba, $\underline{1}(3): 1-16$.

BARNES, R.D. et alii, 1984. Genotype-environment interactions in tropical pines and their effects on the structure of breeding populations. Silvae Genetica, Frankfurt, 33 (6) : 186-198.

BARRICHELO, L.E.G. et alii, 1980. Densidade básica, teor de holocelulose e rendimento em celulose de madeira de Eucalyptus grandis Hill ex Maiden. Silvicultura, São Paulo, $\underline{8}$ (32): $802-808$.

BOGYO, T.P., 1964. Coefficents of :ariation of heritability estimates obtained from variance analyses. Biometrics, Raleigh, 20: 123-129.

BORGES, R. He C.G., 1980. Estimativas de herdabilidades $€$ correlações entre caracteres de crescimento em Eucalyptus grandis W Hill ex Maiden. Viçosa, 42p. (Tese de Mestrado - UFV).

BURDON, R., 1971. Clonal repeatabilities and clone-site in teractions in Pinus radiata. Silvae Genetica, Frankfurt, $\underline{20}(1-2): 33-39$. 
BURDON, R., 1977. Genetic correlation as a concept for studying genotype-environmént interaction in forest tree bre eding. Silvae Genetica, Frankfurt, 26 (5-6): 168-175.

BURLEY, J. e R.H. KEMP, 1973. Centralized planning and international cooperation in the introduction and improvement of tropical trees species. Commonwealth Forestry Re$\underline{\text { view, }}$ Londion, $\underline{52}(4): 335-343$.

BURLEY, J. e D.G. NIKLES (eds.), 1973. Tropical provenance and progeny research and international cooperation. Oxford, Comm. Forestry Institute. 597p.

CAMPBELL, T.E. e MANN Jr., 1974. Growth j.n Loblolly pine spacing study in southwest Louissiana. In: SYMPOSIUM ON MANAGEMENT OF YOUNG PINES. Alexandria. $349 \mathrm{p}$.

CAMPBELL, R.K. e B.C. WILSON, 1973. Spacing-genotype interac tion in Douglas-Fir. Silvae Genetica, Frankfurt, 22(1/2): $15-20$.

CARPIM, M.A. e L.E.G. BARRICHELO, 1983. Variabilidade da densidade da madeira de Eucalyptus spp. In: CONGRESSO Lي TINO-AMERICANO DE CELUlOSE E PAPEL, 3. São Paulo. v.l. $11 \mathrm{p}$. 
COCHRAN, W.G. e G.M. COX, 1965. Diseños experimentales. 2. ed. México, Editorial T'rillas. 661p.

COCKERHAM, C.C., 1963. Estimation of genetic variances. In: HANSON, W.D. e H.F. ROBINSON (ed.) . Statistical genetics. and plant breeding. Washington, National Acad. Sci. National Research Council. p. 53-95.

COElHO, A.S.R.; H.A. MEllO e J.W. SIMOES, 1970. Comportamen to de espécies de eucalipto face ao espaçamento. IPEF, Piracicaba (1): 29-55.

COUTO, L., 1977. Influência do espaçamento no crescimento do Eucalyptus urophylla de origem híbrida, cultivado na região de Coronel Fabriciano, Minas Gerais. Viçosa. 54p. (Tese Mestrado - UFV).

DANIEL, P.W.; U.E. HELMS e F.S. EAKER, 1982. Princípios de Silvicultura. México, McGraw-Hìll. 492p.

DANIELS, J.D., 1984. Role of tree improvement in intensive fo rest management. Forest Ecology and Management,. Ansterdam, $\underline{8}(3 / 4): 161-165$. 
DEPARTAMENTO DE SILVICULTURA ESALQ/USP, 1979. Processo para credenciamento das áreaś de coleta de sementes do Horto de Itatinga, situado no município do mesmo nome, do Estado de São Paulo, pertencentes a USP. (não publicado).

DITLEVSEN, B., 1980. Genética cuantitativa: principios generales y su aplicación práctica en la mejora de árboles forestales. In: FAO/DANIDA. Mejora genética de árboles forestales: Informe sobre el curso de capacitación sobre la mejora genética de ärboles forestales. Roma, FAO/DANIDA. p. $177-188$.

DUDLEY, J.W. e R.N. MOLL, 1969. Interpretation and use of estimates of heritabiitty and genetic variances in plant breeding. Crop Science. Madisun, 9(3): 257-262.

ELDRIDGE, K.G., 1971. Genetically improved Eucalyptus sead for Australian Pulpwood Forest. Appita, 24: 105-109.

ELDRIDGE, K.G., 1972. Genetic variation in the growth of Eucalyptus regrans from altitudinal transect of mount Erica, Victoria. Canberra, Department of primary industry, Forestry and Timber Bureau. 71p. (Bulletin, 46). 
ELDRIDGE, K.G., 1978. Genetic Improvement of Eucalyptus. Sylvae Genetica. Frankfurt, 27(5): 205-209.

FA.LCONER, D.S., 1983. Introducción a 1a Genética Cuantitativa. México, Ed. CECSA. 430p.

FERREIRA, M. e P.Y. KAGEYAMA, 1978. Melhoramento genético da densidade da madeira de Eucalipto. Silvicultura. São Pau$10,4(14): 148-152$.

FISHWICK, R.W., 1976. Estudos de Espaçamentos e Desbastes tm Plantações Brasjleiras. Brasil Florestal. Rio de Janeiro, 7(26): $13-26$.

FONSECA, S.M. da, 1979. Estimação e interpretação dos componentes da variação total em experimentos de melhoramento florestal. In: Curso Práticas Experimentais em Silvicultura. Piracicaba, IPEF. p. $\mathrm{H}_{1}: \mathrm{H}_{20}$.

FONSECA, S.M., da, 1982. Variações fenotípica= e genéticas em Bracatinga Mimosa scabrella Dentham. ESALQ/USP, Piracicaba, 86p. (Dissertação de Mestrado).

FRANKLIN, E.C., 1979. Model relating levels of genetic variance to stand development of North American Conifers. Silvae Genetica. Frankfurt, 28 (5/6): 207-212. 
FRIES, A., 1984. Spacing interaction with genotype and with genetic variation for production and quality traits in a trial of seedlings and grafted clones of scots pine (Pinus sylvestris L.). Silvae Genetica. Frankfurt, 33 (4-5): $145-152$.

GERALDI, I.0., 1977. Estimação de parâmetros genéticos para caracteres do pendão de mi tho (Zea mays L.) e perspectivas de melhoramento. ESALQ/USP, 103p. (Dissertação' de Mestrado) .

GIBSON, G.L., 1982. Genotype-environment interaction in Pinus caribaea. Oxford, Com. For. Inst. 112p.

GODDARD, R.E., 1977. Genotype by environment interaction in slash pine. In: WORLD CONSULTATION ON FOREST TREE BREEDING, 3, Canberra, Proceedings. p. $162-771$.

GUIMARAES, R.F., 1960. Ensaio de espaçamentos em Eucalyptu: saligna Smith para produção de lenha. 2.ed. Rio Claro, CPEF $42 \mathrm{p}$. (Boletim $\mathrm{n}^{\circ} 6$ ).

GUIMARÁS, R.F., 1965. Observaçōcs sobre diâmetros, alturas, sobrevivência e pêso de madeira de E. saligna em vârios esfraçamentos. Anuário Brasileiro de Economia Florestal. Rio de Janeiro, $17(17): 31-45$. 
HARRIS, J.M., 1970. Breeding to improve wood quality. N.Z. For. Serv. Reprint n: 403: 32-36.

JAHROMI, S.; W. SMITH e R. GODDARD, 1976. Genotype x fertilizer interaction in slash pine: variation in phosphate $\left({ }^{33} \mathrm{P}\right)$ incorporation. Forest. Science. Bethesda, 22: 21-30.

JOHNSON, H., 1974. Progeny testing. In: IUFRO GENETIC SABRAO JOINT SYMPOSIA, TOkiO. $7 \mathrm{p}$.

KAGEYAMA, P.Y. e.t alii, 1977. Variação genētica entre e dentro de progênies de Pinus patula Schiedde e Deppe na região de Telêmaco Borba, PR. IPEF, Piracicaba, (15): 21-39.

KAGEYAMA, P.Y., 1979. Determinaçäs de parâmetros genéticos. em espécies florestais. Piracicaba, ESALQ/USP. 40p. (não publicado).

KAGEYAMA, P.Y., 1980. Variação genética em uma população de Eucalyptus grandis (H1ll) Maiden. ESALQ/USP, Piracicaba, 125p. (Tese de Doutoramento).

KAGEYAMA, P.Y. et alii, 1982. Variação genética para deñsi. dade da madeira em progênies de Eucalyptus grandis. Silvicultura. São Paulo, $\underline{8}(28): 318-324$. 
KAGEYAMA, P.Y., 1983. Seleção precoce a diferentes idades em progênies de Eucalyptus grandis (Hil1) Maiden. Piracicaba, ESALQ/USP, 147p. (Tese Livre Docência).

KAGEYAMA, P.Y. e F. PATIÑO-VALERA, 1985. Conservación y manejo de recursos forestales: factores que influyen en la estructura y diversidad de los ecosistemas tropicales. Documento Especial Enviado ao Congreso Forestal Mundial, 9 , México. (no prelo).

KAGEYAMA, I.Y., 1986. Plantação de espécies florestais nativas. In: Relatório do convênio ESALQ/FEALQ/DAEE, Piracicaba, ESAĹn'DCF. (não publicado).

KANG, H., 1980. Designing a tree breeding system. In: MEETING OF CANADIAN TREE IMPROVEMENT ASSOCIATION, 17. Proceedings. Part 2. p.51-66.

KEDHARNATH, S. e R.K. VAKSHASYA, 1977. Estimatives of components of variance, hereditability and correlations among some growth parameters in Eucalyptus tereticornis. In: World Consultation of Forest Tree Breeding, 3, Canberra, Proceedings, Roma, FAO. 21-26. 
LA FARGE, T. e J.F. KRAUS, 1981. Genotype x Environment Interactions of Loblolly Pine Families in Georgia, U.S.A. Silvae Genetica. Frankfurt, 30(4/5): 156-162.

MARQUEZ, S.F., 1985. Genotecnia Vegetal: Métodos, teoria, resultados. México, AGT Editor, v.1, 357p.

MATHESON, A.C., 1978. Genotype-environment interaction. In: NIKLES, D.G. et alii. progress and problems of genetic improvement of tropical forest trees. Oxford, Commonwea1th Forestry Institute, p.227-236.

MATHESON, A.C. e C.A. RAYMOND, 1984a. Effects of thinning in progeny tests on estimates of genetic parameters in Pinus radiata. Silvae Genetica. Frankfurt, $\underline{33}(4 / 5)$ : $125-128$.

MATHESON, A.C. é C.A. RAYMOND, 1984b. Provenance $x$ Environinent interaction, its detection, practical importance and use in tropical forestry. In: IUFRO JOINT MEETING OF WORKING PARTIES AND WORK CONFERENCE ON PROVENANCE AND GENETIC IMPROVEMENT STRATEgIES, 'Mutare. $35 \mathrm{p}$. 
MENCK, A.L. et alii, 1984. Programa de melhoramento genëtico com Eucalyptus saligna na Cia. Suzano de Papel e Celulose. In: SIMPÓSIO INTERNACIONAL: METODOS DE PFODUÇAO E CONTROLE DE QUALIDADE DE SEMENTES E MUDAS FLORESTAIS, Curitiba. Anais. Curitiba, U.F.P. p.40-50.

MESKIMEN, G. e E.C. FRANKLIN, 1978. Spacing Eucalyptus grandis in Southern Florida. Southern Journal of Applied Forestry, Washington, $1(1): 3-6$.

MIRANDA FILHO, J.B., 1978. Princípios de experimentação e anālise estatística. In: PATERNIANI, E. (coord.). Melhoramento de Milho no Brasil. Piracicaba, Fundação Cargill, p. $620-650$.

MORGENSTERN, E.K., 1982. Interactions between genotype site and silvicultural treatment. Information report PI-X. Chalk River, (14): 1-18.

NAMKOONG, G., 1966. Inbreeding effects on estimation of genetic additive variance. FGiest Science. Washington, $\underline{12}(1): 8-13$.

NAMKOONG, G. et alii, 1966. Heritability and gain concepts for evaluating breeding system such as seedling orchards. Silvae Genetica. Frankfurt, 15: 76-84. 
NAMKOONG, G., 1979. Introduction to quartitative genetics in forestry. Washington, USDA. Forest Service. $341 \mathrm{p}$.

NAMKOONG, G. et alii, 1980. A phylosophy of breeding strategy for tropical forest trees. Oxford, Commonwealth Forestry Institute. $67 \mathrm{p}$.

OWINO, F., 1977. Genotype x Environment Interaction and Genotypic Stability in Loblolly. Pine. IV. Correlation Studies. Silvae Genetica. Frankfurt, 26 $6(5 / 6):$ 176-179.

PEREIRA, A.R. et alii, 1982. Implantação de florestas de ciclos curtos sob novos modelos de espaçamentos. Silvicultura. São Paulo, $\underline{8}(28): 429-432$.

PIMENTEL GOMES, F., 1982. Curso de Estatística Experimental. 10.ed. Piracicaba, Livraria Nobel. $430 \mathrm{p}$.

PINTO JR., J.E., 1984. Variabilidade genética em progênies de uma população de Eucalyptus urophylla S.T. Blake da Ilha Florcs - Indonésia. ESALQ/USP, Piracicaba, 166p. (Dissertação de Mestrado). 
PIRES, I.E., 1984. Variabilidade genëtica em progênies de uma população de Algaroba, Prosopis Juliflora (SW.) DC - da região de Soledade, Paraíba. Piracicaba, 94p. (Tese- Mes trado - ESALQ).

QUIJADA, R.M., 1980. Interacciôn genotipo-ambiente. In: FAO/DANIDA. Mejora genëtica de ärboles forestales. Mêrida. p. $231-235$.

REZENDE, G.C. et alii, 1980. Novas tëcnicas de espaçamentos para Eucalyptus spp. Aguas de Säo Pedro, IUFRO. 11p.

ROBINSON, H.F. e C.C. COCKERHAM, 1965. Estimaciön y significaciōn de los parämetros genëticos. Fitotecnia Latinoamericana, Caracas, 2: 23-38.

SHELBOURNE, C., 1972. Genotype environment interaction: its study and its implications in forest tree improvement. In: IUFRO GENETIC SABRAO JOINT SYMPOSIA, Tokio. $28 \mathrm{p}$.

SILVA, J. de C., 1984. Parâmetros da densidade na qualidade da madeira. Piracicaba, ESALQ/DS. $82 \mathrm{p}$.

SILVA, J. de C., 1984. Espaçamentos em povoamentos florestais: efeitos na produtividade, qualidade e na economicidade. Piracicaba, ESALQ/DS. 39p. (não publicado) 
SIMOES, J.W.; R.M. BRANDI; N.B. LEITE E E.A. BALLONI, 1981. Formação, manejo e exploração de florestas com espëcies de räpido crescimento. Brasilia, IBDF. $131 \mathrm{p}$.

SIMOES, J.W. e F. SPINA-FRANÇA, 1983. Produção de madeira em florestas energéticas sob diferentes práticas silviculturais. In: SIMPÓSIO ENERGIA DE BIOMASSA FLORESTAL. Relatório Final. São Pau1o, CESP. p. 1-36.

SMITH, D.M., 1962. The practice of silviculture. 7.ed. New York, John Wiley. $578 \mathrm{p}$.

SNYDER, E.B., 1966. Lattice and compact family block designs in forest genetics. U.S.A. For. Serv. Res. Pap. St. Paul, $\mathrm{NC}(6): 12-17$.

SQUILLACE, A.E.; R.T. BINGHAN; G. NAMKOONG e N.F. ROBINSON, 1967. Heritability of juvenile growth rate and expected ga in from selection in western white pine. Silvae Genetica, Frankfurt, $\underline{16}(1): 1-6$.

SQUILLACE, A.E., 1969. Genotype-environment interactions in forest trees. In: MEETING OF THE IUFRO WORKING GROUP ON QUANTITATIVE GENETICS, 2, Section, 22. New Orleans, USDA. Forest Service. 
TALBERT, J.T., 1980. Genotype environment interactions. In: Tropical tree improvement short course. Raleigh, School of forest resources.

TEIXEIRA, M.B. e S.V. RAUEN, 1973. Ensaio de competição entre progênies de Eucalyptus saligna. In: CONGRESSO FLORES TAL BRASILEJRO, 2, Curitiba. Anajs. Curitiba, FJEP, p. $97-99$.

TUSKAN, G.A. e C.R. MCKJNLEY, 1984. The use of competition indices in advanced-generation selection. Silvae Genetjca, Frankfurt, 33(6): 209-215.

VAN LAAR, A., 1961. Eucalyptus saligna in South Africa. An: Investigation into the Silviculture and Economics. Annale Universitatet Van Stellenbosh, Stellenbosh, 36(A): 1-110.

VAN LAAR, A., 1978. The growth of unthinned Pinus patula in relation to spacing. South African Forestry Journal, Johannesburg, (107): 3-11.

VAN WYK, G., 1976. Early growth results in a diallel progeny test of Eucalyptus grandis. Silvae Genetica, Frankfurt, 25: $126-132$. 
VAN WYK, G., 1978. Progress with the Eucalyptus grandis bree ding programm in the Republic of South Africa. In: WORLD CONSULTATION ON FOREST TREE BREEDING, e, Canberra, FO-FTB$77-3 / 13.5 \mathrm{p}$.

VENCOVSKY, R., 1978. Herança quantitativa. In: PATERNIANI, E. (coord.). Melhoramento de milho no Brasil. Piracicaba, Fundação Cargill. p. 122-199.

VITAL, B.R. e R.M. DELlA LUCTA, 1980. Procedêricia de sementes e qualidade da madeixa de Eucaluptus grandis Hill ex Maiden. Revista Ârvore, Viçosa, 4(2): 170-178.

WILCOX, M.D., 1980. Genetic improvement of Eucalyptus in New Zealand. New Zealand Journal of Forestry Science, Rotom rua, $10(2): 342-459$.

WRIGHT, J.W., 1976. Introduction to forest genetics. New York, Academic Press. 463p.

YEISER, J.L.; J.P. VAN BUIJTENEN e W. LOWE, 1981. Genotype $x$ environment interactions and seed movements for loblolly pine in the western gulf region. Silvae Genetica, Frankfurt, $30(6): 196-200$.

ZOBEL, B. e J. TALBERT, 1984. Applied Forest tree improvenent. New York, John Wiley \& Sons, 505p. 
.190.

\section{APENDICE}


1. Médias de temperatura (mínima, máxima e média) mensais e pre cipitação, no Parque Florestal "Guarujā", Município de Avaré, São Pauro.

\begin{tabular}{|c|c|c|c|c|c|c|}
\hline \multirow{2}{*}{ Meses } & \multicolumn{4}{|c|}{ Temperatura média $(O C)$} & \multirow[t]{2}{*}{ Precipitasão } & \multirow[t]{2}{*}{$(\min )$} \\
\hline & Mínima & Máxima & Média & & & \\
\hline \multicolumn{7}{|l|}{1983} \\
\hline Fevereiro & 18 & 36 & 26 & & 137 & \\
\hline Março & 14 & 35 & 24 & & 195 & \\
\hline Abril & 14 & 32 & 24 & . & 160 & \\
\hline Maio & 14 & 33 & 25 & & 333 & \\
\hline Junho & 04 & 36 & 18 & & 238 & \\
\hline Julho & 09 & 32 & 22 & & 07 & \\
\hline Agosto & 04 & 34 & 20 & & 00 & . \\
\hline Setembro & 09 & 35 & 21 & & 194 & \\
\hline Outubro & 10 & 34 & 23 & & 117 & \\
\hline Novembro & 13 & 35 & 26 & & 128 & \\
\hline Dezembro & 18 & 36 & 26 & & 231 & \\
\hline \multicolumn{7}{|l|}{1984} \\
\hline Janeiro & 25 & 39 & 27 & & 261 & \\
\hline Feverciro & 18 & 38 & 28 & & 93 & \\
\hline Março & 14 & 38 & 26 & . & 65 & \\
\hline Abril & 10 & 32 & 22 & & 125 & \\
\hline Maio & 11 & 41 & 25 & & 81 & \\
\hline Junho & 06 & 33 & 20 & & 00 & \\
\hline Julho & 06 & 32 & 20 & & 05 & \\
\hline Agosto & 01 & 33 & 18 & & 68 & \\
\hline Setembro & 05 & 33 & 20 & & 92 & \\
\hline Outubro & 12 & 39 & 25 & $\therefore$ & 71 & \\
\hline Novembro & 13 & 38 & 25 & & 08 & \\
\hline Dezembro & 14 & 35 & 25 & & 127 & \\
\hline \multicolumn{7}{|l|}{1985} \\
\hline Janeiro & 20 & 31 & 25 & & $\ldots \quad 145$ & \\
\hline
\end{tabular}

Fonte: Estação Meteorolögica do Parque Florestal "Guarujâ", RIPASA: 
2. Identificação das árvores matrizes utilizadas no teste de progênies de Eucalyptus saligna Smith, conforme a numeração utilizada pelo Instituto de Pesquisas e Estudos Florestais, do Departamento de Ciências Florestais da ESALQ.

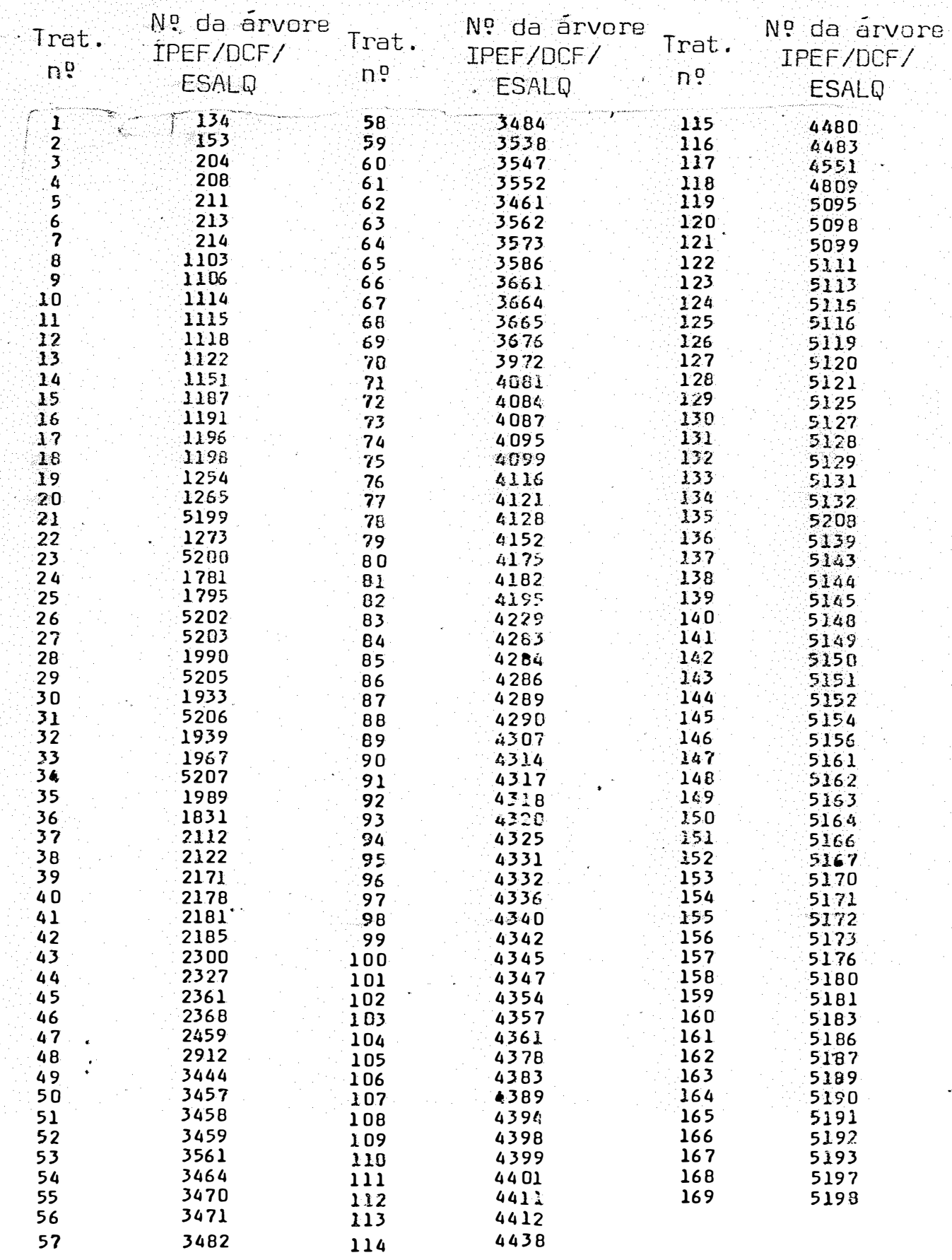

